\title{
Basic Principles and Recent Advances in Magnetic Cell Separation
}

\author{
Marie Frenea-Robin *(i) and Julien Marchalot *
}

Citation: Frenea-Robin, M.; Marchalot, J. Basic Principles and Recent Advances in Magnetic Cell Separation. Magnetochemistry 2022, 8, 11. https://doi.org/10.3390/ magnetochemistry 8010011

Academic Editor: Lotfi Bessais

Received: 10 December 2021

Accepted: 9 January 2022

Published: 14 January 2022

Publisher's Note: MDPI stays neutral with regard to jurisdictional claims in published maps and institutional affiliations.

Copyright: () 2022 by the authors Licensee MDPI, Basel, Switzerland. This article is an open access article distributed under the terms and conditions of the Creative Commons Attribution (CC BY) license (https:// creativecommons.org/licenses/by/ $4.0 /)$.
Univ Lyon, Université Claude Bernard Lyon 1, INSA Lyon, Ecole Centrale de Lyon, CNRS, Ampère, UMR5005, 69622 Villeurbanne, France

* Correspondence: marie.robin@univ-lyon1.fr (M.F.-R.); julien.marchalot@insa-lyon.fr (J.M.)

\begin{abstract}
Magnetic cell separation has become a key methodology for the isolation of target cell populations from biological suspensions, covering a wide spectrum of applications from diagnosis and therapy in biomedicine to environmental applications or fundamental research in biology. There now exists a great variety of commercially available separation instruments and reagents, which has permitted rapid dissemination of the technology. However, there is still an increasing demand for new tools and protocols which provide improved selectivity, yield and sensitivity of the separation process while reducing cost and providing a faster response. This review aims to introduce basic principles of magnetic cell separation for the neophyte, while giving an overview of recent research in the field, from the development of new cell labeling strategies to the design of integrated microfluidic cell sorters and of point-of-care platforms combining cell selection, capture, and downstream detection. Finally, we focus on clinical, industrial and environmental applications where magnetic cell separation strategies are amongst the most promising techniques to address the challenges of isolating rare cells.
\end{abstract}

Keywords: magnetophoresis; continuous flow separation; rare cell isolation; magnetic labeling; micro-magnetofluidics

\section{Introduction}

Cell separation is a critical step in biological and biomedical research areas as diverse as biodetection, drug testing, tissue engineering, cell-based therapies and clinical diagnostics. Isolating a cell population from a heterogeneous sample enables the identification, study, and analysis of specific cell types, while reducing contamination from others. Many criteria must be considered in the choice of a cell separation strategy, depending on the application and its requirements and constraints in terms of throughput, purity, viability of recovered cells, yield, labeling, ease of use, cost and processing time. For instance, minimizing cell loss and maximizing cell purification efficiency are often crucial aspects in cell-based therapeutics [1], where consistency of the isolated cell population is essential to ensure adapted cell transplant. Despite the variety of already existing cell purification approaches, there is a constantly increasing demand for the development of separation devices with improved performance, capable of processing large sample volumes, while enabling the accurate sub-selection of potentially rare target cell populations.

Magnetic-activated cell sorting (MACS) and fluorescent-activated cell sorting (FACS) are amongst the most widely used cell separation approaches, together with density gradient methods and methodologies based on adhesion [2]. FACS cell sorters represent powerful equipment enabling high cell-sorting rates ( $>50,000$ cells $/ s)$ [3] and high purity (approaching 100\%). Moreover, FACS is quite versatile since it allows separation of cells according to their surface markers, as well as size and granularity, based on fluorescent properties or scattered light. Multicolor staining is also possible with some instruments, which enables purification of rare populations that can only be differentiated by their combined expression of several surface markers. The autofluorescence displayed by some 
cells can, however, interfere with specific fluorescent probes in flow cytometric analysis [4], although it can be exploited in some cases [5].

In the case of MACS, the cell-targeting principle (which consists in attaching magnetic beads to a specific cell population) and the physical separation process (i.e., selectively retaining those cells on a column) are more intimately related, as they conjointly exploit magnetism, which facilitates sorting [6]. Consequently, MACS commercial instruments are less sophisticated, more compact, and much less expensive than FACS. There are a variety of benchtop magnetic cell sorters, either manual (e.g., BioLegend MojoSort ${ }^{\mathrm{TM}}$, Invitrogen DynaMag ${ }^{\mathrm{TM}}$ ) or automated (e.g., Miltenyi Biotech autoMACS ${ }^{\circledR}$, RoboSep $^{\mathrm{TM}}$ from STEMCELL Technologies), and, in contrast to FACS, the intervention of a trained operator is usually not required for their utilization, which is also less time consuming [7]. However, with FACS, cells are analyzed and sorted one-by-one, while MACS performs a bulk separation. Therefore, despite a lower processing time with MACS, a higher purity of the desired cell population is typically achieved by FACS [1,8]. A number of studies have attempted to compare the ability of FACS and MACS to isolate specific cell populations $[7,9,10]$.

There exist many alternatives to FACS and MACS for cell separation, exploiting other approaches and which have reached different stages of technical maturity. In particular, the constant need for integration of more functionalities and for improved performance has led to the development of a variety of microfluidic tools exploiting different sorting mechanisms and making use of different cell phenotypic traits. Despite the fact that these new technologies face a set of challenges for their commercialization [11], they offer great promise for pushing the limits encountered with cell separation and meeting a range of needs, from debulking to rare cell isolation $[12,13]$ and detection. Many research efforts are currently focused on building cell-sorting devices relying on microfabrication technology, because miniaturization offers many advantages, such as reduced footprint, as well as low power and reagent consumption. Moreover, working at the microscale allows amplification of actuation effects when forces involved depend on a field gradient, due to favorable scaling laws, as is the case with active separation methods, such as dielectrophoresis, acoustophoresis, optical trapping and magnetophoresis. There are several recent reviews in the literature that provide an overview of microfluidic passive [14,15] and active [16-20] separation methods, the former exploiting more or less complex microchannel geometries and the latter requiring the use of a field source. Passive separation methods mainly exploit differences in cell size and shape. Despite their simplicity, they offer less flexibility than active methods, which exploit more separation criteria. Compared with other active methods, such as dielectrophoresis [21,22] or acoustophoresis [23,24], those based on magnetic force offer a variety of advantages [25], including higher portability, absence of heating effects potentially detrimental to cells (except in some specific cases where electromagnets are used), this independently of the ionic strength [26], and high selectivity conferred by magnetic cell tagging whenever required. Additionally, magnetic fields can penetrate non-magnetic materials, such as plastics or glass, commonly used in cell separation experiments. Moreover, miniaturized solutions based on magnetism can be built on existing protocols and reagents already developed for MACS, while being applicable to much lower volumes of suspension. The combination of magnetism and microfluidics, also referred to as magnetofluidics, provides increased spatial and temporal control of cells, improving the resolution of separation and facilitating continuous flow processing [27]. It also enables the integration of entire analytical procedures, from sample pretreatment to downstream analysis, inside a unique device which can be used at the point of care.

The present paper aims to provide an overview of recent research in magnetic cell separation, covering various aspects, from specific cell targeting strategies to the design and fabrication of new magnetic separation platforms and related applications. The next section introduces the theoretical background required for understanding the role of the different parameters affecting the efficiency of the magnetic separation process. 


\section{Theoretical Background}

\subsection{Magnetic Behavior of Materials}

This paragraph aims to briefly describe the magnetic behavior of materials at play in magnetic cell separation, namely cells, water and ions composing their immersion medium, magnetic beads attached to cells and magnetic field sources.

Faraday's work has shown that any substance can be magnetized in the presence of a magnetic field [28]. The magnetic susceptibility of a material, denoted $\chi$, reflects its ability to magnetize in the presence of an external magnetic excitation generated using permanent magnets or conductors carrying an electric current. It is defined as the ratio of magnetization $M$ (magnetic dipole moment per unit volume) to the applied magnetizing field intensity $H$. Materials can be classified into three main categories based on the value of $\chi$ : diamagnetic $(-1<\chi<0)$, paramagnetic $\left(0<\chi<\sim 10^{-2}\right)$ or ferromagnetic $\left(\chi>10^{-2} \rightarrow \sim 10^{5}\right)$. The relation between $M$ and $H$ is linear in the first two groups and non-linear in the last one (Figure 1).
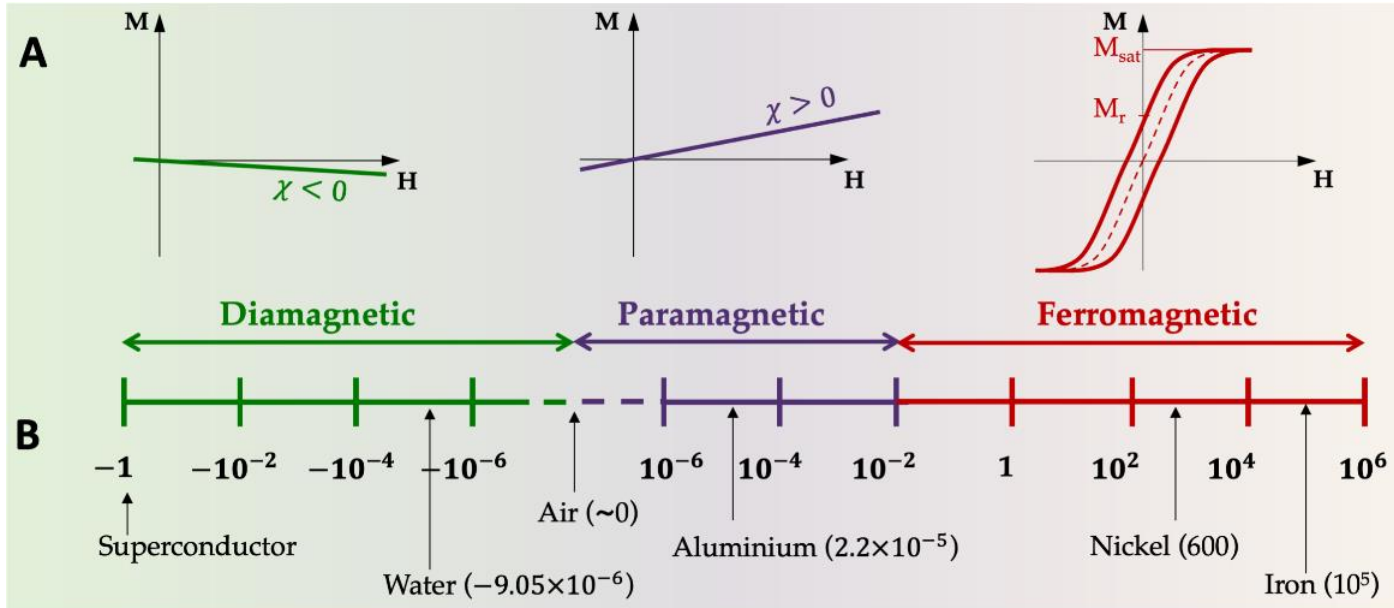

Figure 1. Magnetic properties of materials. (A) Magnetization curves (M-H) of diamagnetic, paramagnetic and ferromagnetic materials. The dotted line on the red curve corresponds to superparamagnetic behavior. $\mathrm{M}_{\text {sat }}$ and $\mathrm{M}_{\mathrm{r}}$ refer to saturation and remanent magnetization, respectively. (B) Classification of materials according to their susceptibility value (volume susceptibility, SI units).

Most cells and other biological materials are diamagnetic and their susceptibility generally falls within a range of about $\pm 20 \%$ from the susceptibility of water $\left(\chi=-9.05 \times 10^{-6}\right.$ in SI units) [29]. There are few exceptions, such as magnetotactic bacteria, which synthesize intracellular nanoparticles of magnetite and use them as tiny compasses to navigate in the direction of the Earth's magnetic field [30-32]. Diamagnetic materials magnetize weakly in the direction opposite to the applied magnetic field. The induced magnetization cancels when the external field is removed.

Paramagnetic materials have a small, positive susceptibility. In these substances, the induced magnetization is also weak, but still hundreds to thousands of times higher than in diamagnetic materials, and points in the same direction as the applied field. On removal of the external magnetic field, paramagnetic materials also lose their magnetism. These substances include ions having unpaired electrons. For instance, manganese $\left(\mathrm{Mn}^{2+}\right)$ and gadolinium $\left(\mathrm{Gd}^{3+}\right)$ ions, used as MRI contrast agents, are paramagnetic.

Ferromagnetic materials exhibit a large, positive magnetic susceptibility. They are magnetized easily and, as the external field is increased, the induced magnetization reaches a limiting stage called saturation $\left(M_{\text {sat }}\right)$. A part of this magnetization is retained after external field removal, which is referred to as remanent magnetization $\left(M_{r}\right)$. The most common ferromagnetic materials are iron, nickel, cobalt and their alloys, and alloys of rare earth metals used for the fabrication of electromagnets or permanent magnets. Superparamagnetism is a form of magnetism which appears in ferromagnetic nanoparticles 
of diameter below several tens of nm [33], exhibiting a single magnetic domain. These particles present a high susceptibility at low magnetic fields, followed by saturation at a few hundreds of mT. Moreover, once the external field has been removed, they do not retain any residual magnetization. Commercial superparamagnetic microspheres used for cell separation are usually composed of superparamagnetic nanoparticles (typically $\mathrm{Fe}_{3} \mathrm{O}_{4}$ magnetite or $\gamma-\mathrm{Fe}_{2} \mathrm{O}_{3}$ maghemite) embedded in a polymeric matrix [34]. The resulting microbeads retain a superparamagnetic property with tunable size. The absence of remanent magnetization prevents their agglomeration and facilitates redispersion after storage. The rich possibilities of coatings combined with the ability to respond to the external magnetic field make magnetic nanoparticles a universal tool for the separation of small molecules, biomolecules and cells. The preparation and applications of magnetic micro- and nano-particles have been extensively reviewed elsewhere [35-39].

\subsection{Magnetic Force Expression}

Magnetophoresis (MAP) refers to the motion of a particle in a non-uniform magnetic field $\boldsymbol{B}$. A particle placed in such a field can be assimilated to a magnetic dipole of moment $\mathbf{m}$ and of magnetic potential energy $U_{m a g}=-m . B$. It then undergoes a force $\boldsymbol{F}_{\text {mag }}=-\nabla U_{m a g}=(\boldsymbol{m} . \nabla) \boldsymbol{B}$, where $\nabla$ is the del operator. For a diamagnetic or paramagnetic particle of volume $V_{p}$ and susceptibility $\chi_{p}$ immersed in a medium of susceptibility $\chi_{m}$, the net magnetic moment is given by: $\boldsymbol{m}=\left(\chi_{p}-\chi_{m}\right) V_{p} \mathbf{H}$, which leads to:

$$
\boldsymbol{F}_{m a g} \approx\left(\chi_{p}-\chi_{m}\right) \frac{V_{p}}{\mu_{0}}(\mathbf{B} . \nabla) \mathbf{B}=\frac{V_{p} \Delta \chi}{2 \mu_{0}} \nabla B^{2}
$$

with $\Delta \chi=\left(\chi_{p}-\chi_{m}\right)$ and $\mu_{0}=4 \pi 10^{-7} \mathrm{H} / \mathrm{m}$.

Equation (1) shows that the existence of a force acting on the particle is conditioned by use of a non-uniform field, as the term $\nabla B^{2}$ reflecting the spatial variation of $B^{2}$ cancels when the field is uniform. It also indicates that the direction of particle displacement depends on the sign of the magnetic contrast factor $\Delta \chi$. If $\Delta \chi>0$, the particle moves to regions of highest field strength. This case, referred to as positive MAP, typically occurs when a paramagnetic particle $\left(\chi_{p}>0\right)$ is immersed in an aqueous medium $\left(\chi_{m}<0\right)$. Conversely, if $\Delta \chi<0$, the particle is repelled towards regions of lowest field strength. This phenomenon, called negative MAP, is, for instance, encountered when a diamagnetic cell $\left(\chi_{p}<0\right)$ is placed in a medium enriched in paramagnetic ions $\left(\chi_{m}>0\right)$ [40-42].

The linear response described by Equation (1) applies well to biological particles, which are generally diamagnetic. In the case of superparamagnetic beads, often used to label cells, this response may prove to be non-linear. Beyond a certain intensity of the excitation field, the magnetization is no longer proportional to the applied field and becomes constant $\left(M_{s a t}\right)$. The force is then proportional to the gradient of $B$, rather than that of $B^{2}$ :

$$
\boldsymbol{F}_{\text {mag }}=M_{s a t} V_{p}\left(\boldsymbol{e}_{\boldsymbol{B}} \cdot \nabla\right) \mathbf{B}
$$

where $e_{B}$ is a unit vector, oriented according to the direction of the applied field.

Equations (1) and (2) also show that the greater the spatial variation of the magnetic field (large value of the gradient term), the higher is the force intensity. This explains why downscaling permanent magnets can greatly increase the attraction forces generated on magnetic nanoparticles [43,44]. A permanent magnet can be assimilated to a dipole of moment $m$ producing a magnetic field of expression:

$$
\boldsymbol{B}(r)=\left(\frac{\mu_{0}}{4 \pi}\right) \frac{3(\boldsymbol{m} \cdot \boldsymbol{u}) \boldsymbol{u}-\boldsymbol{m}}{r^{3}}
$$

with $m=V M$ where $V$ is the volume of the magnet and $M$ its magnetization and $u$ is the unit vector oriented from the dipole to the considered point, separated by a distance $r$. While the distance $r$ varies in $L$, the volume $V$ varies in $L^{3}$. As the magnetization is an intrinsic property of the material, it remains constant and consequently the moment $m$ also 
varies in $L^{3}$. Thus, according to Equation (3), the field magnitude normalized by magnet size remains unchanged when downscaling, as illustrated in Figure 2A,B. At the same time, when the scale is reduced by a factor $k$, the field gradient, defined as the field variation over the distance, is multiplied by $k$ (Figure $2 \mathrm{C}$ ). The volume force acting on a magnetic particle is thus also multiplied by the reduction factor $k$, as it is proportional to the field gradient (from Equation (1) or Equation (2)). Further analysis of magnetic scale reduction effects can be found elsewhere [45].
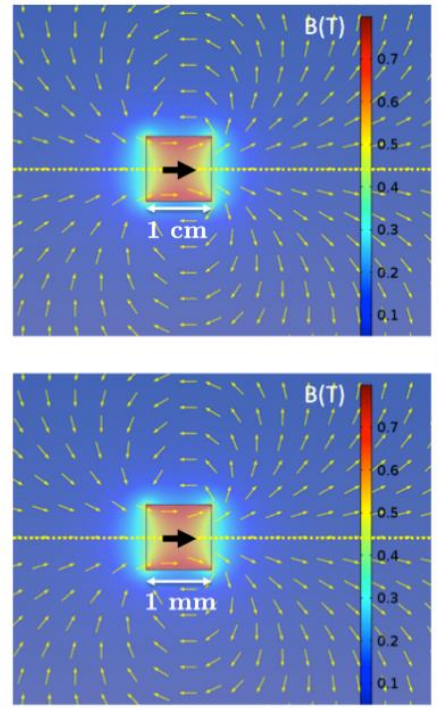

A.
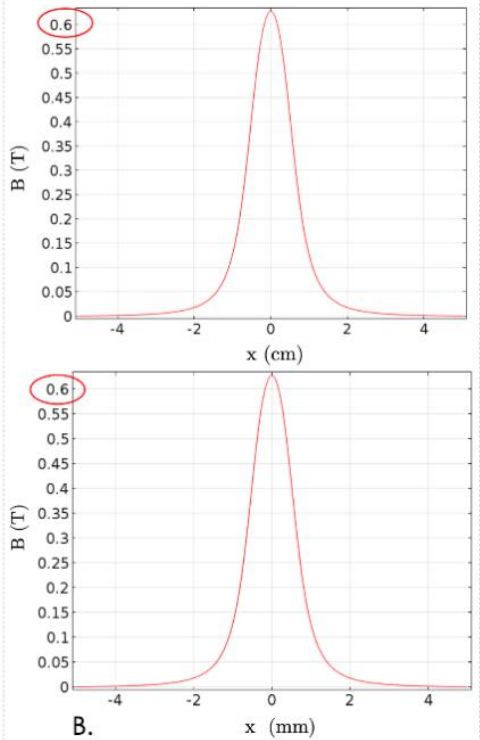
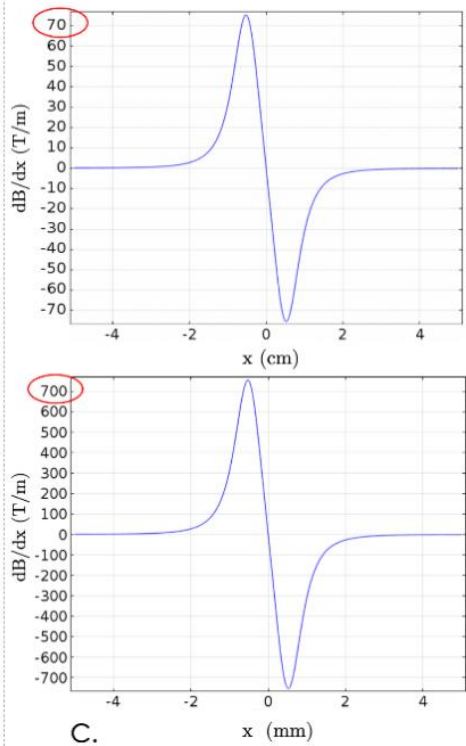

Figure 2. Illustration of scale reduction effects on the magnetic field produced by a permanent magnet. (A) The topology of the field around the magnet is preserved upon downscaling. (B) If we reduce the size of the magnet by a factor of 10 , the field magnitude is identical at the same distance reduced by a factor of 10. (C) At the same time, the magnetic field gradient is multiplied by a factor of 10 .

\subsection{Magnetophoretic Velocity}

The magnetophoretic velocity of a magnetic bead in a fluid is determined by both the magnetic force expression and by the resistance exerted by the surrounding fluid, or viscous drag, which can be evaluated by the Stokes equation:

$$
F_{d}=6 \pi \eta R v
$$

where $\eta$ is the dynamic viscosity of the fluid and $v$ is the particle velocity relative to the fluid.

For a spherical magnetic bead of radius $R$ under magnetic saturation, the magnetophoretic mobility can be deduced from Equations (2) and (4) leading to $\xi=\frac{2 R^{2} M s a t}{9 \eta}$, (by neglecting gravitational and buoyant forces and assuming a quasi-static motion of particles, the two forces equal each other $\boldsymbol{F}_{\boldsymbol{d}}+\boldsymbol{F}_{\text {mag }}=\mathbf{0}$ ). For instance, the values of $\xi_{1}$ and $\xi_{2}$ for two particles of similar magnetic saturation $M_{\text {sat }}=15 \mathrm{kA} / \mathrm{m}$ and respective radii $R_{1}=2 \mu \mathrm{m}$ and $R_{2}=200 \mathrm{~nm}$ in water are $\xi_{1}=1.33 \times 10^{-5} \mathrm{~m}^{2} /$ (T.s) and $\xi_{2}=1.33 \times 10^{-7} \mathrm{~m}^{2} /$ (T.s). Consequently, magnetic field gradients of $\sim 75 \mathrm{~T} / \mathrm{m}$ and $\sim 7500 \mathrm{~T} / \mathrm{m}$ would be required, respectively, to induce a motion of these particles at $1 \mathrm{~mm} / \mathrm{s}$, relative to their suspending medium (for $\eta$ of water). To make similar estimations in the case of cells labeled with $N$ nanoparticles of volume $V_{p}$, one should consider different expressions for $\boldsymbol{F}_{\boldsymbol{d}}$ and $\boldsymbol{F}_{\text {mag }}$, because in the first, the radius is that of the equivalent radius of the labeled cell $R_{e q}$, while in the second, only the (total) volume of magnetic material should be taken into account, leading to $\boldsymbol{F}_{\boldsymbol{d}}=6 \pi \eta R_{e q} \boldsymbol{v}$ and $\boldsymbol{F}_{\text {mag }}=N M_{s a t} V_{p}\left(\boldsymbol{e}_{\boldsymbol{B}} . \nabla\right) \mathbf{B}$.

As shown above, the knowledge of the magnetic moment of a particle or of a magnetically labeled cell enables estimation of its magnetophoretic velocity. Conversely, the 
observation of particle displacement under a magnetic field can be used to determine its magnetic moment and potentially evaluate the average number of magnetic particles grafted on a cell. This can be particularly useful for magnetic force evaluation required in the process of designing new cell separators and establishing new protocols. Cell tracking velocimetry (CTV), a technique pioneered by Chalmers and colleagues [46], allows estimation of these parameters based on the velocity measurement of individual particles microscopically tracked in a nearly constant, well-defined, magnetic energy gradient. It has previously been applied to magnetic particles, polystyrene microbeads, and magnetically labeled and unlabeled cells $[47,48]$.

In summary, the force exerted on labeled cells results from a complex interplay between several parameters, such as the particle size, magnetization, number of particles grafted on each cell, and the magnetic field gradient. The concentration of magnetic objects also has an impact on their migration through the effect of cooperative MAP (i.e., chain formation and aggregation) [49].

\section{Cell Selection Strategies}

This section focuses on the different approaches available to target cells, based either on magnetic tagging or on label-free strategies. Table 1 summarizes their respective advantages and disadvantages. 
Table 1. Comparison of several cell selection strategies.

\begin{tabular}{|c|c|c|c|}
\hline $\begin{array}{l}\text { Cell Selection } \\
\text { Strategy }\end{array}$ & Advantages & Disadvantages & $\begin{array}{l}\text { References } \\
\text { (Examples) }\end{array}$ \\
\hline \multicolumn{4}{|c|}{ METHODS INVOLVING CELL LABELLING } \\
\hline \multicolumn{4}{|c|}{ Based on Cell Surface Markers } \\
\hline Antibodies & $\begin{array}{ll}\text { - } & \text { Fast and specific } \\
\text { - Widespread use, wide range of commercial antibody-magnetic bead } \\
\text { conjugates/labeling kits available }\end{array}$ & $\begin{array}{l}\text { - } \quad \text { High cost of production, including purification [50] } \\
\text { - } \quad \text { Preparation based on animal systems } \\
\text { - } \quad \text { Antibodions between batches } \\
\text { even though release approaches tend to emerge } \\
\text { - The inherent immunogenicity of antibodies may be an } \\
\text { obstacle for downstream therapeutic applications [51] } \\
\text { - Undesired intracellular signaling cascades can be } \\
\text { triggered upon binding }\end{array}$ & {$[52-54]$} \\
\hline Aptamers & $\begin{array}{l}\text { Small size }(\varnothing: 2-3 \mathrm{~nm}) \text {, which enables accurate quantification of the cell surface } \\
\text { markers and enhanced resolution in identifying distinct subpopulations. } \\
\text { - } \quad \text { Obtained by chemical synthesis, which leads to reproducible properties and } \\
\text { facilitates modification with functional groups and different labels } \\
\text { - } \quad \text { Simple and cost-effective production } \\
\text { - } \quad \text { Aptamers are stable under various conditions (pH, temperature) }[55,56] \\
\text { - } \quad \text { Cells captured using aptamers can be released using nucleases or the aptamer's } \\
\text { complementary strand } \\
\text { - } \quad \text { Low to no immunogenicity } \\
\text { Long-shelf life }\end{array}$ & $\begin{array}{l}\text { - Application of aptamer is still in development phase, due } \\
\text { to well-established use of antibodies } \\
\text { - Time consuming selection process } \\
\text { - Possible endocytosis of the aptamer-magnetic particle } \\
\text { conjugates [57] (although this is exploited for therapeutic } \\
\text { applications). }\end{array}$ & [58-61] \\
\hline
\end{tabular}


Table 1. Cont.

\begin{tabular}{|c|c|c|c|c|}
\hline $\begin{array}{l}\text { Cell Selection } \\
\text { Strategy }\end{array}$ & \multicolumn{2}{|l|}{ Advantages } & Disadvantages & $\begin{array}{l}\text { References } \\
\text { (Examples) }\end{array}$ \\
\hline \multicolumn{5}{|c|}{ Based on DNA or RNA internalization } \\
\hline Reporter genes & \multicolumn{2}{|c|}{ No need to identify existing cell surface markers for antibody recognition } & Transgenic sequences remain in the target genome [1] & {$[62,63]$} \\
\hline Fishing & \multicolumn{2}{|c|}{ - Applicable to unculturable cells for which antibodies are not available } & $\begin{array}{l}\text { - cell genetic content is preserved inside the cell but the } \\
\text { latter is no longer viable due to treatment with chemical } \\
\text { fixative such as paraformaldehyde. }\end{array}$ & [64-67] \\
\hline Endocytosis & \multicolumn{2}{|c|}{ Simple way to provide magnetic properties to cells, such as macrophages } & Some internalization pathways are limited to certain cells & [68] \\
\hline \multicolumn{5}{|c|}{ LABEL FREE APPROACHES } \\
\hline $\begin{array}{l}\text { Intrinsic magnetic } \\
\text { properties of cells }\end{array}$ & \multicolumn{2}{|c|}{$\begin{array}{l}\text { No need for magnetic labeling, which leaves the cells untouched and reduces the } \\
\text { cost, less time consuming } \\
\text { Applicable in classical biological media }\end{array}$} & $\begin{array}{l}\text { - Very few cells present a significant susceptibility contrast } \\
\text { with biological media (almost exclusively applicable to } \\
\text { blood fractionation and magnetotactic bacteria) }\end{array}$ & [69-73] \\
\hline $\begin{array}{l}\text { Adjusted properties } \\
\text { of the medium }\end{array}$ & Ferrofluids & $\begin{array}{ll}\text { - } & \text { Applicable to "non magnetic" particles } \\
\text { - } & \text { No need for magnetic labeling (reduces } \\
\text { - } & \text { cost, less time consuming) } \\
\text { - } & \text { Possible exploitation of a repulsive force } \\
\text { - } & \text { Flexible fluid propertios [76] }\end{array}$ & $\begin{array}{l}\text { - Possible accumulation of ferrofluid nanoparticles in areas } \\
\text { of high magnetic flux density } \\
\text { - The opaque nature of a ferrofluid makes visualization of } \\
\text { the sample difficult [74]. } \\
\text { - Nanoparticle coating required to ensure better } \\
\text { biocompatibility and colloidal stability }\end{array}$ & [77-81] \\
\hline
\end{tabular}




\subsection{Approches Based on Cell Surface Markers}

The most popular approaches for selective purification of cells based on magnetic or fluorescence-assisted cell sorting are based on affinity. They rely on the use of ligands targeting cell-surface markers and offer the advantage of providing high target specificity [50]. In the case of magnetic cell separation, the selectivity is ensured by decorating magnetic beads with biological ligands, such as antibodies and proteins, or synthetic ligands, such as aptamers and peptides [58].

\section{- $\quad$ Antibodies}

The predominant approach used for magnetic cell separation exploits antibodies conjugated to magnetic beads, thereby forming a complex that selectively binds to cells expressing the corresponding epitope (direct labeling). Alternatively, cells can be labeled using a two-step procedure (indirect labeling), in which they are first labeled with a primary antibody directed against a cell surface marker. Then, a secondary antibody conjugated to a magnetic bead binds to the unconjugated primary antibody or to a molecule (e.g., biotin, fluorochrome) itself conjugated to the primary antibody. This two-step indirect labeling method may be indicated for applications involving antigens that are not expressed clearly, as greater sensitivity can be achieved due to the signal amplification resulting from the increased number of sites available for MNP attachment [82,83]. There also exists a third approach, used for instance in the EasySep ${ }^{\mathrm{TM}}$ technology from STEMCELL, in which a tetrameric antibody simultaneously targets a cell surface marker and a magnetic particle added in a second step [47,84] (Figure 3A).

Many commercial anti-body magnetic bead conjugates are readily available for sorting cells of various species (e.g., MACS ${ }^{\circledR}$ MicroBeads from Miltenyi Biotec), as well as kits (e.g., Dynabeads ${ }^{\circledR}$ antibody coupling kit, Thermo Fisher) allowing coupling of antibodies, lectins, enzymes, etc., to the surface of superparamagnetic beads to enable the targeting of nearly any cell types [85].

Considerable effort has also been directed toward the development of MNP surface modifications and coatings improving cell targeting efficiency [86]. The binding capacity of the ligand can be increased using two-step [87] or multivalent binding strategies based on tentacle-like structures [83,88,89] (Figure 3B). For instance, antibody-functionalized dendrimers have been proposed as a solution to improve the hydrophilicity and increase the amount of antibodies conjugated with MNPs, thereby enhancing the magnetophoretic mobility of targeted cells [90].

A

1)

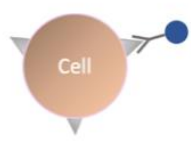

2)

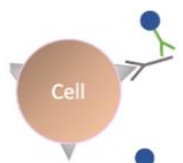

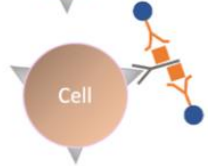

3)

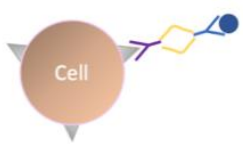

B

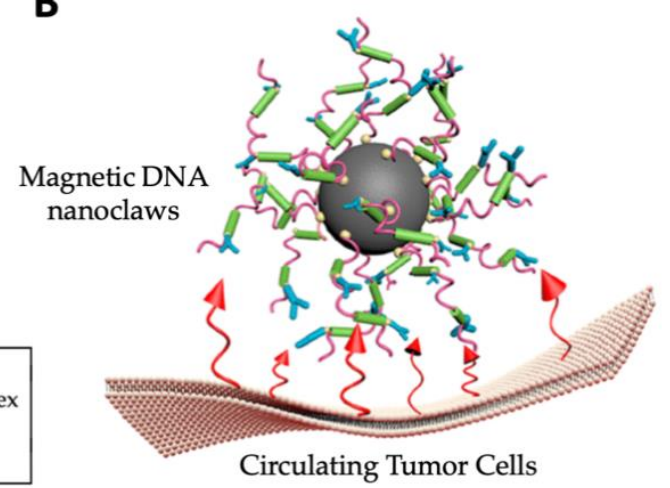

Figure 3. Different labeling strategies based on antibodies. (A) (1) Direct labeling strategy. (2) Indirect labeling. (3) Use of a tetrameric antibody complex, presenting two different affinities, one for the target molecule on the cell and one for the magnetic particle. (B) Illustration of multivalent binding strategy. Adapted with permission from [89]. Copyright 2019, American Chemical Society.

Depending on the downstream application, it must be considered whether the target cells should be labeled with antibodies for subsequent positive selection (i.e., the labeled 
cells are retained in the isolated fraction due to attraction by the magnetic field, Figure 4A), or if a negative selection strategy should be used to instead deplete the sample of an undesired cell subset (i.e., unwanted cells are labeled, leaving the wanted cells untouched for downstream use, Figure 4B). The main advantage of a positive selection strategy is high purity, and this strategy is particularly well-suited for isolation of rare, precious cells [91]. In some situations, it may be complicated to design an antibody cocktail allowing depletion of all the non-target cells, which makes negative selection less efficient in this respect. Relying on a large panel of antibodies for depletion also tends to increase the cost. There are, however, some limitations to positive selection, especially when the expression level of target antigen is low. Moreover, the antibody-magnetic bead conjugate may cause unwanted intracellular signaling or cell activation and affect downstream use of the cells. In such cases, negative selection is the preferred strategy.

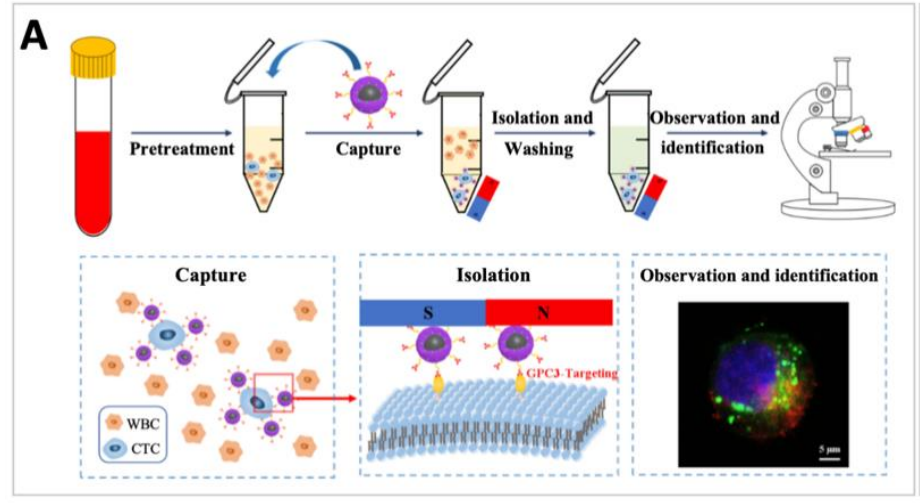

B

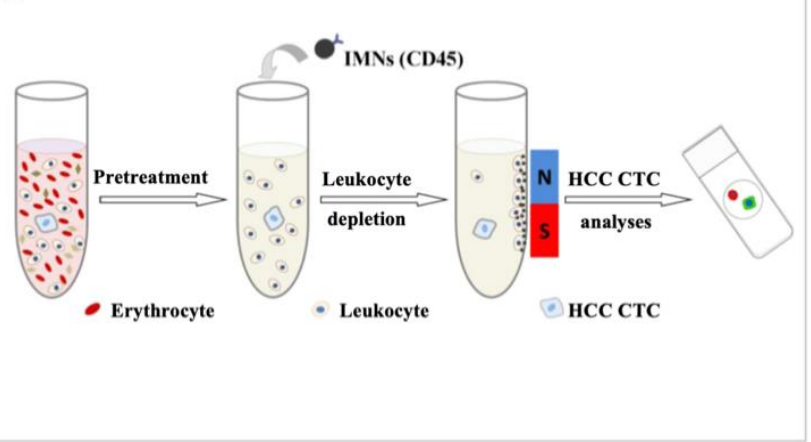

Figure 4. Positive vs negative selection strategies. (A) Positive selection of circulating hepatocellular carcinoma cells (HCC) from blood using nanoparticles targeting GPC3 antigen. Reproduced with permission from [92]. Copyright (C) 2021 Chu et al. (B) Negative selection strategy for efficient isolation of HCC using anti-CD45 antibody-modified magnetic nanospheres. Adapted with permission from [93]. Copyright 2016 Elsevier.

Recovery of label-free cells after sorting can also be of interest, for instance, when cell culturing is desired in the downstream [94]. Several commercial kits allow the detachment of the beads from the cells if needed, such as EasySep ${ }^{\mathrm{TM}}$ Release from STEMCELL ${ }^{\mathrm{TM}}$, Dynabeads $^{\circledR}$ FlowComp ${ }^{\mathrm{TM}}$ or Dynabeads ${ }^{\circledR}$ CELLection $^{\mathrm{TM}}$. In the latter, a DNA linker between the beads and antibodies is cleaved using DNase after cell isolation, thereby detaching beads and leaving only the antibodies on the cell surface. MACS Multisort kits [95] also contain a release reagent which enzymatically removes the beads before a second labeling step with beads directed against a second marker. Lu et al. have developed a biotin-triggered decomposable immunomagnetic system, in which peptide-tagged antibodies designed by chemical conjugation are specifically immobilized on engineered protein-coated magnetic beads. The interaction between peptide and engineered protein could be competitively destroyed by biotin treatment, enabling the release of captured, circulating tumor cells (CTCs) [96].

Miltenyi Biotech has recently commercialized a technology based on releasable antibodies enabling the removal of both magnetic beads and antibody fragments after positive cell selection. In the so-called REAlease ${ }^{\mathrm{TM}}$ technology, available both for fluorescent- [97] and magnetic- [98] based sorting, conventional antibodies are replaced by engineered antibody fragments having low affinity for surface markers in their monomeric state. When multimerized in a biotinylated REAlease complex, they bind to cell epitopes with high avidity. Upon addition of a release reagent, the complex dissociates from the cell surface due to monomerization of the antibody fragments. Antibody-magnetic bead conjugates are then released from the cell surface and previously blocked epitopes become available again for re-labeling, which allows for sequential positive selection steps based on multiple markers. 
Despite their widespread use, antibody-based labeling approaches have some drawbacks, such as high cost [99], sensitivity to temperature, and complex production. Therefore, some other targeting probes, such as DNA aptamers or recognition peptides, tend to be developed for cell isolation [100].

\section{- Aptamers}

Aptamers consist of single-stranded DNA or RNA oligonucleotides (typically 20-100 nucleotides), with engineered affinity and selectivity for a specific target molecule. They are synthetic compounds selected from libraries of random oligonucleotide sequences by an iterative process called SELEX (Systematic Evolution of Ligands by EXponential Enrichment), involving incubation of oligonucleotides with the specific target for identification of high affinity sequences after several rounds of selection and amplification [101]. Through SELEX, aptamers can be practically selected against any targets, including proteins, bacteria, virus and whole cells [102]. Due to their synthetic origin, they can also be selected for toxic agents, as, unlike antibodies, they do not depend on the production of antisera in animals. Their production is cheap and fast and very reproducible properties can be obtained with low inter-batch variability [103]. During synthesis, they can be easily modified to facilitate attachment of enzymes or other functional groups (e.g., amine, thiol) or labels (e.g., biotin, fluorochromes) at defined positions within the sequence, which expands their chemical diversity and allows their immobilization on magnetic beads. Biotin-labeled aptamers can be attached to streptavidin-coated beads, for instance [104]. Aptamers present numerous advantages, including high affinity, low cost and better stability, compared to antibodies. They have matured considerably through the past two decades and many efforts have been made to enrich and detect targeted cells using them. In particular, aptamer-functionalized magnetic particles have attracted great attention in clinical diagnosis [105], for selective extraction of target CTCs [104,106-111] (Figure 5A). Chen et al. have reported undesirable endocytosis of aptamer-conjugated magnetic nanobeads during CTC separation and proposed different strategies to minimize this issue $[57,112]$, such as the use of multimerized aptamer DNA strands, or tentacle DNA, immobilized on magnetic microparticle surface (Figure 5B). The obtained "nanooctopuses" were protected from cellular uptake and maximized capture capacity. They could be removed after cell isolation to allow cell culture through degradation of binding aptamer strands by DNase treatment.

A

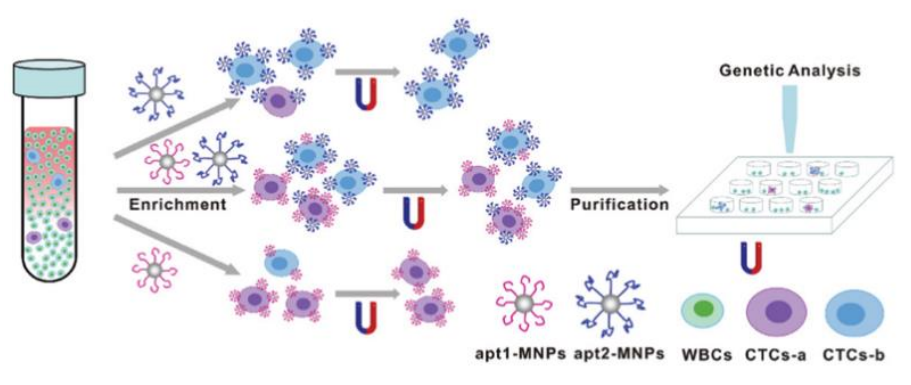

B

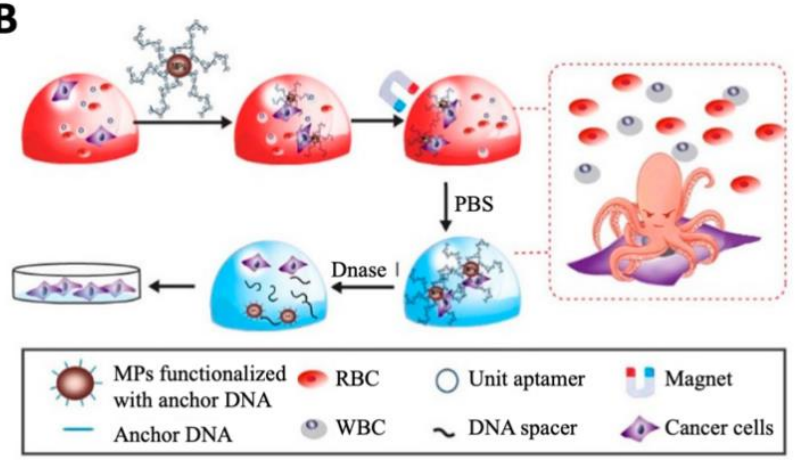

Figure 5. Aptamer-based cell isolation. (A) Aptamer-MNPs cocktail for CTC enrichment prior to genetic analysis. Adapted with permission from [111]. Copyright 2018 WILEY-VCH Verlag GmbH \& Co. KGaA, Weinheim. (B) Aptamer-functionalized MNP, mimicking the tentacles of an octopus for efficient CTC capture. Adapted with permission from [57]. Copyright 2019, American Chemical Society.

Other approaches can be used for cell release after capture $[113,114]$, such as temperaturemediated disruption of cell-aptamer interaction [115]. Gray et al. used magnetic beads loaded with the epidermal growth factor receptor (EGFR)-binding antagonistic aptamer E07 to specifically isolate EGFR-expressing cells. They demonstrated that E07 binding 
could be reversed by using an "antidote" [116] oligonucleotide complementary to the aptamer, giving a pure population of ligand-free EGFR(+) cells [51]. A similar approach was proposed by Kacherovsky et al. to isolate CD8+ T cells from PBMCs with MACS, prior to aptamer binding disruption [117].

Although great improvements have been achieved, and despite the compelling advantages of aptamers, aptamer magnetic separation still faces obstacles for its widespread use, partly due to lack of mature, standardized protocols and commercially available kits, compared to its antibody-based counterpart. Many efforts relying on multidisciplinary research are, then, still required to translate aptamer-based studies into more common practice [118].

\section{- Other ligands}

Peptides are short chains of amino acids offering great potential as synthetic affinity ligands for bioseparation, due to their small size, good chemical stability, and lower production cost, compared to antibodies. The selection of cell-specific peptides can be performed with different approaches, such as phage-display peptide-library screening $[50,119,120]$. Bai et al. identified a peptide with high binding affinity to the epithelial cell adhesion molecule EpCAM, a widely used biomarker for CTC detection (Figure 6A). This peptide was attached onto MNPs through biotin-streptavidin interaction and the functionalized MNPs could capture breast, prostate and liver cancers from spiked human blood with an efficiency (90\%) and purity (93\%) comparable to MNPs functionalized with anti-EpCAM antibodies [121]. The same group adopted a similar approach with a peptide demonstrating high affinity for human epidermal growth factor receptor 2 (HER2) [100]. Ding et al. have demonstrated the applicability of the GE11 peptide for specific targeting toward EGFR [122], a transmembrane protein overexpressed in many cancers [123]. They developed EGFR peptide magnetic nanovesicles based on a derivative of this peptide, which demonstrated high affinity for EGFR-positive cancer cells and have been used for efficient detection of CTCs (Figure 6B).
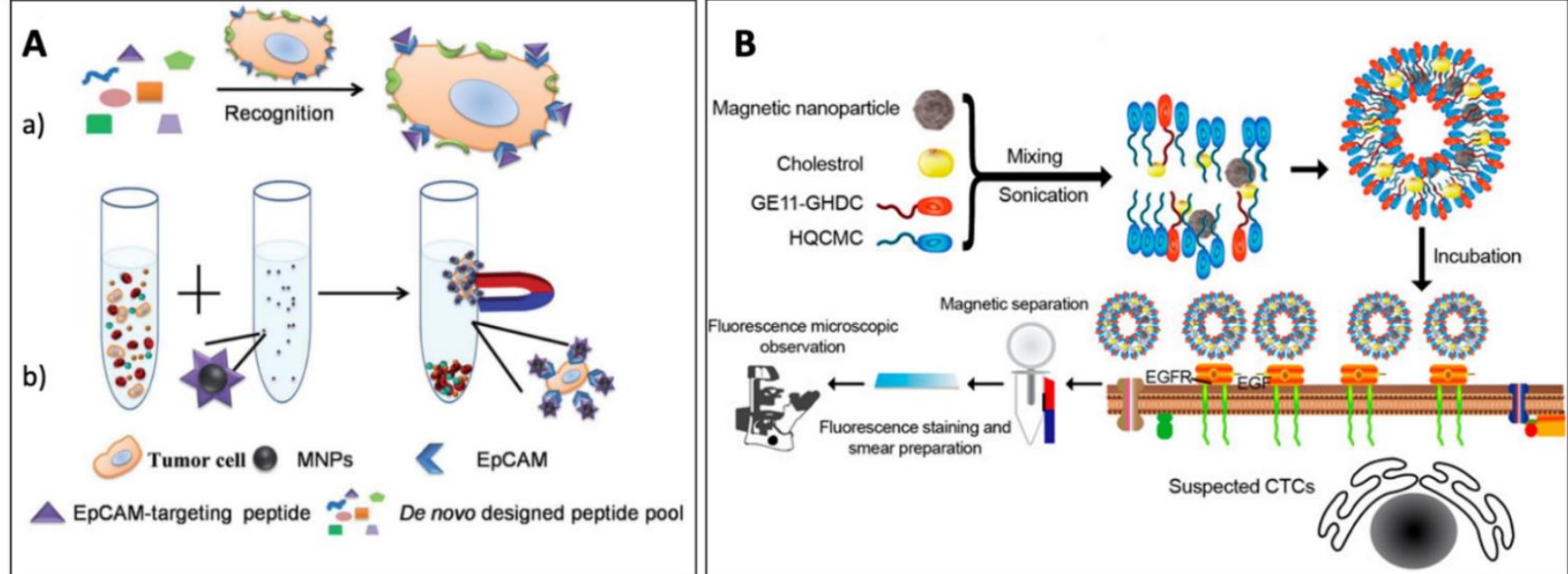

Figure 6. Peptide-based cell isolation. (A) Schematic illustration for (a) peptide screening and (b) tumor cell isolation using peptide modified magnetic particles. Republished with permission of the Royal Society of Chemistry from [121]; permission conveyed through Copyright Clearance Center, Inc. (B) Construction of peptide magnetic nanovesicles with high affinity for EGFR-expressing cancer cells for enhanced capture of CTCs. Adapted with permission from [122] Copyright ( 2016 American Chemical Society.

Peptide ligands can also be engineered to enable the control of their binding activity and, therefore, allow for cell release upon exposure to different stimuli [50]. For instance, Day et al. have developed azobenzene-cyclized peptide ligands with light-controlled 
affinity for target proteins. Light triggers a cis/trans isomerization of the azobenzene, which results in a structural rearrangement of the cyclic peptide from a non-binding to a binding configuration. Their photo-switchable peptides targeted vascular cell adhesion marker 1 (VCAM1), and the light-activated biorecognition activity of these peptides was demonstrated on brain microvascular endothelial cells expressing this marker [124].

Folic acid (FA) can also be used as a targeting ligand as folate receptors are overexpressed in various cancer cells, including breast, lung, kidney and ovarian cancers, the expression in these carcinomas being 100-300 times higher than on healthy cells [125,126]. FA is a vitamin of small size (compared to antibodies), inexpensive, and non-immunogenic. Liu et al. demonstrated ovarian cancer detection from whole blood using FA conjugated magnetic iron oxide (IO) nanoparticles, obtained by immobilizing FA conjugated to diamine PEG (polyethylene glycol) on carboxylated IO nanoparticles via ethyl (dimethylaminopropyl) carbodiimide/N-hydroxysuccinimide (EDC/NHS) coupling. The separation efficiency of spiked ovarian cancer SKOV3 cells in whole blood mixed with IO-FA nanoparticles was $61.3 \%$ for an abundance of 450 cells in $1 \mathrm{~mL}$ [127]. The same group demonstrated detection of ovarian cancer CTCs using BSA-coated magnetic nanoprobes modified with FA through a PEG linker [128]. To increase the labeling efficiency, they also proposed a two-step binding strategy for FA attachment on magnetic particles, exploiting multivalent binding characteristics of the biotin-streptavidin system [129]. This streptavidin-biotin mediated amplification could also be combined with FA conjugation on polyamidoamine (PAMAM) dendrimers, providing a cascade amplification system [130].

\subsection{Approches Based on DNA or RNA Internalization}

- Integration of reporter genes

Cell-sorting methods based on affinity rely on the identification of a target receptor on the cell of interest. However, transgenic approaches can also be used to induce expression of a surface marker which can be recognized by a ligand coupled to MNPs [62]. Mejia-Pous et al. developed a transposon-mediated gene transfer technique to transfect cells with a plasmid construct harboring both the desired transgene and a surface marker coding sequence for subsequent cell isolation using MACS [131]. The MACSelect ${ }^{\mathrm{TM}}$ Sys- $^{-}$ tem, commercialized by Miltenyi Biotec, enables the enrichment of cells transfected with a vector encoding truncated CD4 molecules or low-affinity nerve growth factor receptor (LNGFR) surface markers, used either for cotransfection with a vector containing a gene of interest or for cloning the gene of interest. After cell transfection, cells expressing the marker are magnetically labeled with MACSelect MicroBeads for subsequent enrichment using a MACS separator. The fact that the expressed antigen lacks its intracellular domain could reduce the risk of immunogenicity [132].

Matheson et al. developed an antibody-free magnetic cell sorting strategy, in which transfected or transduced cells co-express a gene or shRNA of interest with a cell surface affinity tag comprising a 38-amino-acid streptavidin-binding peptide. Cells could then be isolated after incubation with streptavidin-conjugated magnetic beads. Magnetic particle detachment could also be achieved through competition by incubation with excess biotin, leaving cells ready for use in downstream applications [63]. Genetically modified primary human CD4+ T cells have been enriched at a purity of $99 \%$ using this approach. Recently, Shen et al. have shown that HeLa cells could be transfected with a plasmid containing a gene encoding the K3 coiled-coil-forming peptide to induce its expression on the cell membrane and use it as a selection marker for sorting [133] (Figure 7). Cells were immobilized using iron oxide particles coupled to the E3 peptide, interacting with $\mathrm{K} 3$ to form a heterodimeric coiled coil system with a micromolar dissociation constant. The coiled-coil peptides could be degraded by trypsin, allowing cell detachment from the particles. 


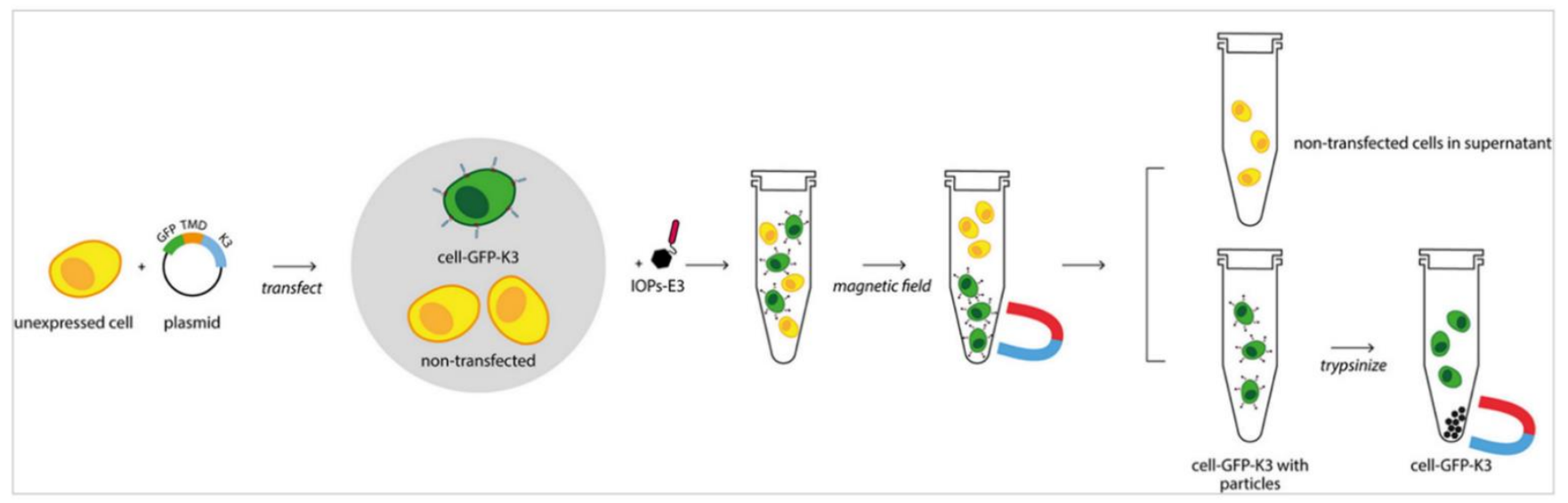

Figure 7. Specific isolation of cells transfected with a plasmid encoding the K3 coiled-coil forming peptide. Reprinted with permission from [133].

- $\quad$ Magnetic fishing

Other approaches based on DNA were also developed in the field of microbiology, to answer the need of cultivation-independent methods for sorting of bacterial cells. The use of antibody-based sorting techniques may be hampered by the need to recover enough antigenic molecules to produce antibodies, which limits their application to culturable bacteria, representing only a small percentage of prokaryotic cells. In this context, the combination of fluorescence in situ hybridization (FISH), using fluorescently labeled oligonucleotides that target rRNA, and flow cytometry, has become a method of choice for detection of bacteria in environmental samples [134]. A magnetic version of this approach was proposed by Stoffels et al., who introduced the concept of probe-based cell fishing [64]. This approach implies in situ hybridization of biotin-labeled polynucleotide transcript probes with specific regions of the target bacteria rRNA. Due to the probe size, it was hypothesized [135] that some probes or partial probes remain outside the cell, therefore allowing anchorage of streptavidin-coated paramagnetic beads and subsequent isolation using a magnetic field. Cells isolated using this method are not viable due to the fixation step performed with a chemical fixative (typically paraformaldehyde), aiming at denaturing the bacterial cell wall and achieving crosslinking of proteins. Nevertheless, fixed bacteria remain whole cells fully exploitable for subsequent genomic analysis. Pivetal et al. combined this approach (Figure 8A), referred to as MISH (magnetic in situ hybridization), with the use of a microfluidic cell sorter obtained by integrating a permanent micromagnet array in a PDMS microchannel. The target Escherichia coli DH10 cells were enriched from an initial concentration of $0.04 \%$ to a final concentration of $98.46 \%$ from an artificial cell mixture [136]. To enlarge the panel of possible rRNA sequences that can be targeted, Royet et al. proposed an approach inspired by HCR-FISH [137], using a combination of MISH and HCR (hybridization chain reaction) [66] (Figure 8B). The same approach was recently validated on a eucaryotic cell model by Bastian et al. [67]. 

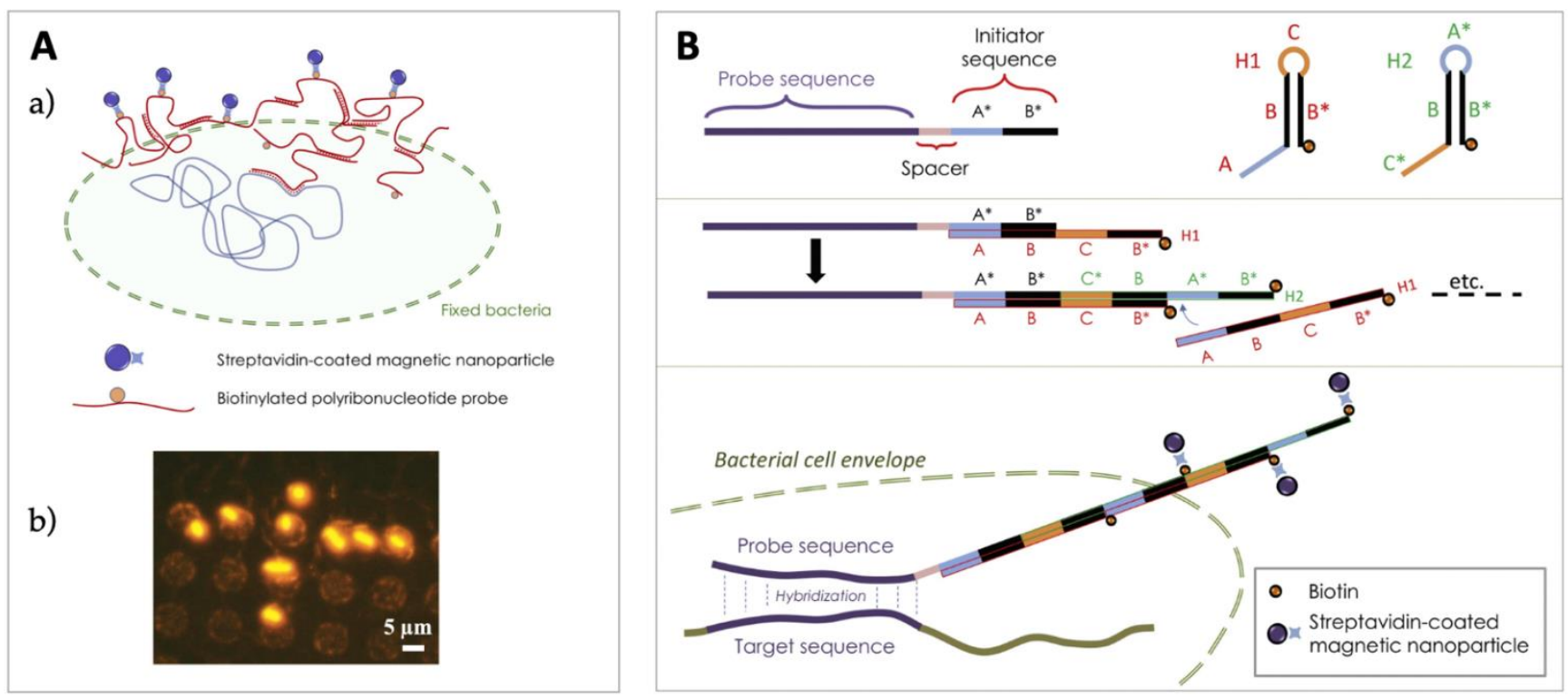

Figure 8. Magnetic fishing. (A) (a) Schematic illustration of magnetic in situ hybridization. (b) E. coli bacteria targeted by this approach and trapped on an array of $7.5 \times 7.5 \mu \mathrm{m}^{2}$ magnets. Reprinted with permission from [65]. Copyright ( 2014 Elsevier B.V. B. Principle of HCR-MISH. (A) (a) and (B) reprinted with permission from [66]. Copyright @ 2018 Elsevier B.V.

\subsection{Endocytosis-Mediated Labeling}

Diamagnetic cells can also acquire a magnetic load through the endocytosis process, by which they internalize substances from their external environment. Based on this natural process, MNPs can be transported into cells by vesicles invaginated from the plasma membrane. The kinetics of endocytosis depends on the involved pathways $[138,139]$ which in turn depend on both the cell type and features of the nanoparticle, such as charge/surface chemistry, shape and size. The quantity of nanoparticles internalized by cells can be adjusted by tuning their initial concentration in the solution, as well as the incubation time [140]. Robert et al. have demonstrated that monocyte-derived macrophages could be separated from their respective native monocytes in a microfluidic magnetophoresis device based on their increased endocytotic capacity. A purity of more than $88 \%$ and an efficacy higher than $60 \%$ were achieved, at a throughput of 10 to 100 cells.s ${ }^{-1}$ [68].

\subsection{Label-Free Magnetic Cell Sorting}

Magnetic cell separation usually relies on a preliminary cell labeling step. However, this approach has some drawbacks, such as cost and difference in magnetic responses from one cell to another due, for instance, to variability in marker expression across a cell population. Label-free cell-sorting approaches based on negative MAP (or "diamagnetophoresis") are therefore an appealing alternative to this well-established strategy. They offer the great advantage of leaving the cell unaffected, which is an asset for downstream use or analysis.

\subsubsection{Adjusting Magnetic Properties of Cell Surrounding Medium}

Manipulation of diamagnetic cells (often referred to as "non-magnetic"), usually requires tuning of their magnetic properties through magnetic labeling or MNP internalization to obtain significant forces, as developed in the previous section. This strategy essentially allows the application of an attractive MAP force. It is, however, possible to apply a repulsive magnetic force on cells by instead increasing the susceptibility of their surrounding medium, thereby increasing the absolute value of the susceptibility contrast factor $\Delta \chi=\left(\chi_{p}-\chi_{m}\right)$ (in Equation (1)), which becomes negative. In these conditions, unlabeled particles are pushed towards low field intensity regions. This so-called "magneto-Archimedes effect", combined with microfluidics, offers a wide range of applica- 
tions, which were recently reviewed $[78,141,142]$. While many studies concern trapping, focusing or separation of particles, such as polystyrene beads employed as an easy-to-use model (for calibration and optimization), we focus here on biological cell separation, which has benefited from progress made in the synthesis of biocompatible fluids. Exploitation of diamagnetic repulsion enables manipulation of cells, while avoiding the need for cell-bead conjugation and associated washing steps, and reduces the dispersion of behaviors in terms of ligand-receptor interactions or endocytotic capacity, even for the same type of cells [68]. Increasing the value of $\chi_{\mathrm{m}}$ can be achieved by using a paramagnetic salt solution or a ferrofluid. Paramagnetic fluids offer the advantages of low cost and transparency, which allows visualization of suspended particles [143]. They are generally prepared by using paramagnetic metal ions, such as $\mathrm{Mn}^{2+}$ and $\mathrm{Gd}^{3+}$, and an organic chelating agent or halide, such as diethylenetriaminepentaacetic acid (DTPA), which can bind to these metal cations $[40,142]$. Chelation of gadolinium by organic ligands was shown to decrease its toxicity to acceptable ranges. Halide salts, such as $\mathrm{MnCl}_{2}$ [144] or $\mathrm{GdCl}_{3}$ [26] and MRI contrast agents, such as Gd-DTPA [26,40], have been used in experiments with cells. However, the concentration of paramagnetic solutions must be limited, as possible adverse effects on cells have been reported above a few tens of $\mathrm{mM}$, such as inhibition of cell division [40]. The magnetic susceptibility of prepared solutions, and, by extension, the magnetic contrast factor value $\Delta x$, consequently remain low. This manipulation strategy is, therefore, preferably combined with the use of integrated magnetic structures capable of producing high magnetic field gradients [41]. Using this approach, Shen et al. successfully achieved label-free separation of U937 cells from RBCs with $>90 \%$ purity and $10^{5}$ cells $/ \mathrm{h}$ throughput using a $40 \mathrm{mM} \mathrm{Gd-DTPA} \mathrm{solution} \mathrm{[74]} \mathrm{(Figure} \mathrm{9A).} \mathrm{Recently,} \mathrm{Sarigil} \mathrm{et} \mathrm{al.} \mathrm{could}$ detect adipogenic differentiated cells mixed with a stem cell population based on magnetic levitation in a paramagnetic medium containing gadolinium. Under the influence of the magnetic field, cells were pushed towards a position at which the magnetic and buoyancy force balanced, depending on their densities [145].

On their side, ferrofluids are colloidal suspensions of monodomain ferromagnetic nanoparticles in a "non-magnetic" fluid [146]. Their magnetic susceptibility is significantly greater than that of paramagnetic fluids. The nanoparticles, around $10 \mathrm{~nm}$ in diameter, are typically made of magnetite $\left(\mathrm{Fe}_{3} \mathrm{O}_{4}\right)$ or maghemite $\left(\mathrm{Fe}_{2} \mathrm{O}_{3}\right)$ and coated with a surfactant to improve biocompatibility and ensure colloidal stability [147]. Commercial ferrofluids (such as water-based Ferrotec's EMG series [148]), as well as custom-made biocompatible ferrofluids [79] have been used for cell or bacteria manipulation. The biocompatibility of several magnetic liquids was examined by Zhao et al. [142]. Concentration of magnetic nanoparticles in ferrofluids should also be carefully adjusted as light diffraction makes it difficult to directly observe cells, unless fluorescent markers are used [32]. An overview of the ferrofluid-related designs and applications was given by Zhao et al. in a recent review [76]. The Mao group has used ferrofluid-based negative MAP to separate cancer cells from blood cells by exploiting their size difference [77,79,149] (Figure 9B). Liu et al. gave a detailed overview of fundamentals of ferrohydrodynamic cell separation in the specific case of CTCs and presented a new strategy for their efficient isolation using diamagnetic repulsion combined with magnetophoretic attraction of MNP-labeled, unwanted WBCs [80]. 
A

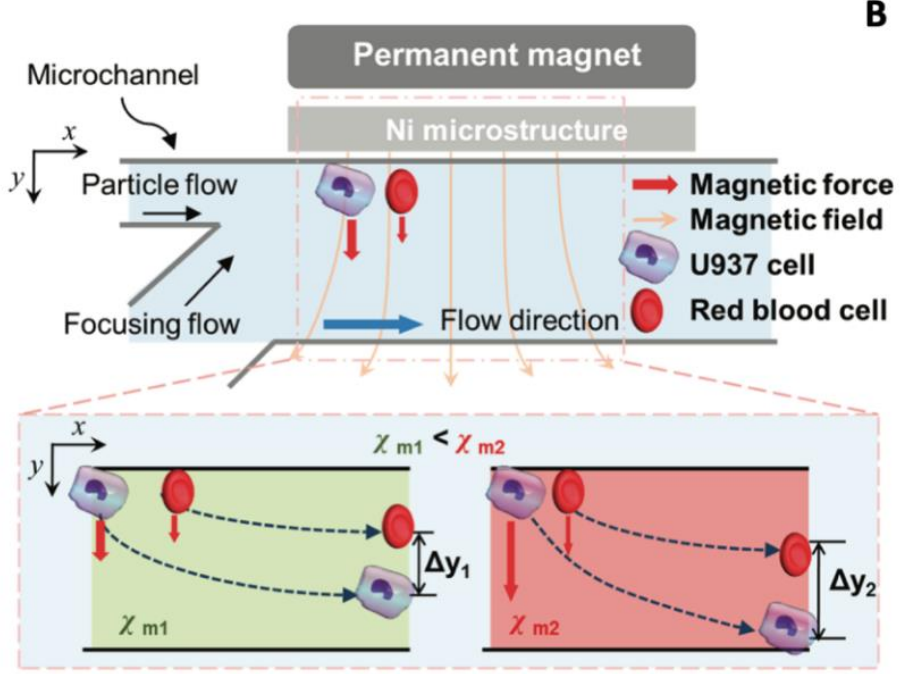

(a)

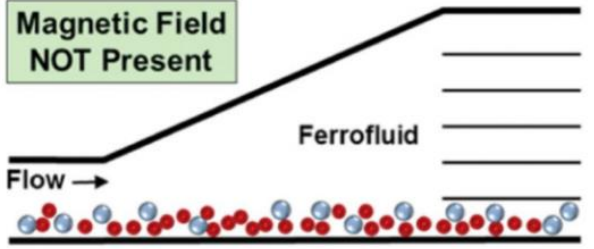

(b)

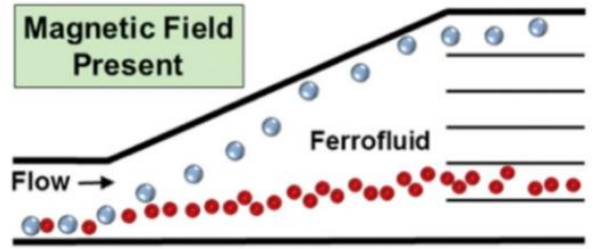

Permanent magnet
( HeLa cell

Blood cell

Figure 9. Label-free magnetic cell sorting. (A) Microfluidic cell separation based on the difference in magnetic repulsive forces between two cells of different size in a paramagnetic salt solution. The separation efficiency can be enhanced by increasing medium magnetic susceptibility from $\chi_{\mathrm{m} 1}$ to $\chi_{\mathrm{m} 2}$. Reprinted with permission from [74]. Copyright (C) 2012, American Chemical Society. (B) Illustration of cell separation in a ferrofluid. HeLa cells and smaller blood cells are deflected from their laminar flow paths towards two different outlets by magnetic repulsion forces. Reprinted with permission from [79]. @ 2015 WILEY-VCH Verlag GmbH \& Co. KGaA, Weinheim.

\subsubsection{Exploiting Cell Intrinsic Magnetic Properties}

As stated in Section 2.1., most biological cells are composed of water, a diamagnetic substance. However, specific cells contain paramagnetic materials and can then be separated from others based on their intrinsic susceptibility. The presence of iron atoms in hemoglobin makes the RBCs less diamagnetic than water $[150,151](\Delta \chi>0)$ in their deoxygenated state, in contrast to other blood cells, such as platelets and WBCs. These cells are therefore submitted to positive and negative MAP forces, respectively, and can be separated in microfluidic devices under continuous flow. To compensate for the low value of magnetic contrast factor $\Delta \chi$, when cells are in their native state, high magnetic field gradients, as produced by integrated microstructures, are usually required [70-73]. Interestingly, Shamloo et al. have proposed reinforcing the effect of high magnetic field gradients produced by a ferromagnetic track using a sheath flow directing cells toward it, where the gradient was maximum. The negative magnetic force exerted on diamagnetic CTCs and WBCs was then sufficient to repel them efficiently from the ferromagnetic wire, where RBCs were attracted [152].

\section{Cell Separation Devices}

\subsection{Magnetic Cell Separator Designs}

As indicated by Equations (1) and (2) (for unsaturated and saturated dipole, respectively), the force exerted on a magnetically labeled cell depends on its magnetic moment and on the magnetic field gradient (see Section 2). As a result, the choice of a magnetic separator depends on the type of magnetic particles used to label cells (see Table 2).

Conventional magnetic separators, based on simple magnets producing low magnetic field gradients $(<100 \mathrm{~T} / \mathrm{m}$, LGMS: low gradient magnetic cell separators [49]), are used for the separation or cells labeled with relatively large particles (size $>1 \mu \mathrm{m}$ ) with strong magnetic moments. They belong to the category of "open gradient magnetic separators" (OGMS), meaning that they do not exploit inserts of high-permeability materials [153]. They offer the advantages of simple design and compatibility with use of standard laboratory tubes, which reduces the cost compared to solutions based on dedicated columns. One of the most well-known separators of this type is the DYNAL ${ }^{\mathrm{TM}}$ magnet from Invitrogen, 
used in combination with Dynabeads ${ }^{\mathrm{TM}}$ particles. These polymer particles, embedding superparamagnetic nano-inclusions, are uniform in size, with a typical diameter of between 1 and $5 \mu \mathrm{m}$ (Figure 10A). Even though large size magnetic beads provide a fast magnetic response, they present several drawbacks, such as reduced binding capacity compared to their nanometer-sized counterparts, potential for sedimentation and possible adverse effects on cells due to the large shear forces involved. In this respect, a negative cell selection strategy can be more appropriate. Moreover, large magnetic particles also strongly affect the light scatter signature of the cells to which they are bound when analyzed by FACS [154].

High gradient magnetic separators (HGMS) enable circumvention of some of these limitations. They exploit matrices of ferromagnetic material to locally distort the magnetic field, thereby producing much stronger magnetic field gradients. As a result, significant magnetic forces can be obtained, even on cell-magnetic bead complexes displaying a weak magnetic moment. This type of separator therefore permits the separation of cells labeled with nano-sized particles (Figure 10B). The magnetic matrices used in HGMS have been reviewed by Ge et al. [155]. This is the principle exploited in the MACS technology, developed by Miltenyi Biotec [156]. The cell mixture is introduced in high-gradient magnetic cell separation columns containing a matrix composed of superparamagnetic spheres, which are sufficiently spaced so that unlabeled cells can move freely between them (Figure 10C). When the column is placed in a MACS Separator (strong magnet), the spheres distort the field lines, producing strong field variations, i.e., strong field gradients (up to $10^{4} \mathrm{~T} / \mathrm{m}$ [157]). The high forces thereby generated retain cells labeled with MACS MicroBeads. Once the column is extracted from the magnet, the bead matrix can no longer retain the labeled cells and they can be eluted. The separation process can be automated, as is the case in the CliniMACS and AutoMACS systems produced by Miltenyi Biotec. Minimal labeling with only a small amount of MicroBeads (50 nm in size) is sufficient to ensure effective cell separation, which is one of the main advantages of the technology, as it reduces the risk of cell perturbation. Moreover, nanosized particles have a higher binding capacity, due to higher surface-to-volume ratio and reduced steric hindrance, which allows grafting of numerous particles on the cell surface. Their binding kinetics are also faster compared with microsized beads.

Table 2. Characteristics of some commercial cell separation technologies and their respective advantages and disadvantages.

\begin{tabular}{|c|c|c|c|c|c|c|}
\hline Separator & Beads & Typical Bead Size & Technology & Advantages & Disadvantages & Ref. \\
\hline $\begin{array}{l}\text { DYNAL } \\
\text { (Invitrogen) }\end{array}$ & Dynabeads & $1-5 \mu \mathrm{m}$ & OGMS, LGMS & $\begin{array}{ll}\text { - } & \text { Simple, } \\
\text { - } & \text { column-free } \\
- & \text { Low cost } \\
- & \text { Fast } \\
& \text { separation }\end{array}$ & $\begin{array}{l}\text { - } \quad \text { Slow binding kinetics due } \\
\text { to large bead size } \\
\text { Potential cell damage due } \\
\text { to large shear forces. }\end{array}$ & [158] \\
\hline $\begin{array}{l}\text { MACS (Miltenyi } \\
\text { biotec) }\end{array}$ & MicroBeads & $50 \mathrm{~nm}$ & HGMS & $\begin{array}{l}\text { Minimal } \\
\text { labeling } \\
\text { required, } \\
\text { resulting in } \\
\text { minimal cell } \\
\text { perturbation. }\end{array}$ & $\begin{array}{l}\text { - Use of dedicated magnetic } \\
\text { column (cost) } \\
\text { - } \quad \text { Potential complications of } \\
\text { column overloading }\end{array}$ & [156] \\
\hline $\begin{array}{l}\text { EasySep }^{\mathrm{TM}} \\
\text { (STEMCELL }^{\text {Technologies) }}\end{array}$ & $\begin{array}{l}\text { EasySep magnetic } \\
\text { nanoparticles } \\
\text { (Dextran-coated } \\
\text { iron particles) }\end{array}$ & $150 \mathrm{~nm}-1.5 \mu \mathrm{m}$ & $\begin{array}{l}\text { OGMS, built } \\
\text { around a multipole } \\
\text { magnet }\end{array}$ & $\begin{array}{ll}- & \text { Simple } \\
- & \text { Column-free } \\
- & \text { Fast } \\
& \text { separation }\end{array}$ & \multirow[t]{2}{*}{ - } & \multirow{2}{*}{ [153] } \\
\hline $\begin{array}{l}\text { BD IMag }^{\mathrm{TM}} \text { (Becton } \\
\text { Dickinson) }\end{array}$ & $\begin{array}{l}\text { BD IMag }^{\mathrm{TM}} \\
\text { particles }\end{array}$ & $230 \mathrm{~nm}$ & $\begin{array}{l}\text { OGMS, based on a } \\
\text { rectangular magnet } \\
\text { assembly }\end{array}$ & $\begin{array}{l}\text { - } \\
\text { fitting } 6 \\
\text { tubes simul- } \\
\text { taneously }\end{array}$ & & \\
\hline
\end{tabular}

There is also a third approach, which is a trade-off between both the previous ones, combining OGMS with optimized magnet design for increased gradient, thereby allowing to take advantage of nanosized particles while avoiding the need for dedicated columns. This approach is used, for instance, in the case of BD Imag ${ }^{\mathrm{TM}}$ separation technology, where 
a rectangular magnet assembly ensures the production of a high field gradient in up to 6 tubes simultaneously, while EasySep ${ }^{\mathrm{TM}}$ exploits a multipole magnetic field coaxial with a standard cylindrical laboratory tube [153]. Chalmers and Zborowski have pioneered this approach $[159,160]$ by designing open-gradient magnetic separation systems exploiting the relatively high magnetic field gradient $(>150 \mathrm{~T} / \mathrm{m}$, up to $286 \mathrm{~T} / \mathrm{m} \mathrm{[69])} \mathrm{that} \mathrm{could}$ be achieved based on a quadrupole magnet design. Cell separation is performed by flow-through MAP in an annular channel placed coaxially inside a quadrupole magnetic field, in a split-flow thin cell fractionation configuration [161] (Figure 10D). The magnet configuration produces a linearly increasing field intensity (Figure 10E) and a constant, high magnetic field gradient along the radial $r$ coordinate. The magnetic force acting on a magnetized particle in such a field is therefore directed along $r$ and has a centrifugal character. It pushes the magnetically labeled cells against the cylinder wall, near the magnet poles, without affecting the unlabeled cells. More recently, the same group has demonstrated that a periodic pattern of permanent magnet blocks (tessellation) could provide a means of increasing the efficiency of the magnetic flow cell sorter design by decreasing the mass of magnet blocks per flow channel. A 9-channel array generated a 5-fold higher throughput compared to the 1-channel array, for the same overall tessellated magnet array dimensions and the same magnet aperture [162] (Figure 10F).
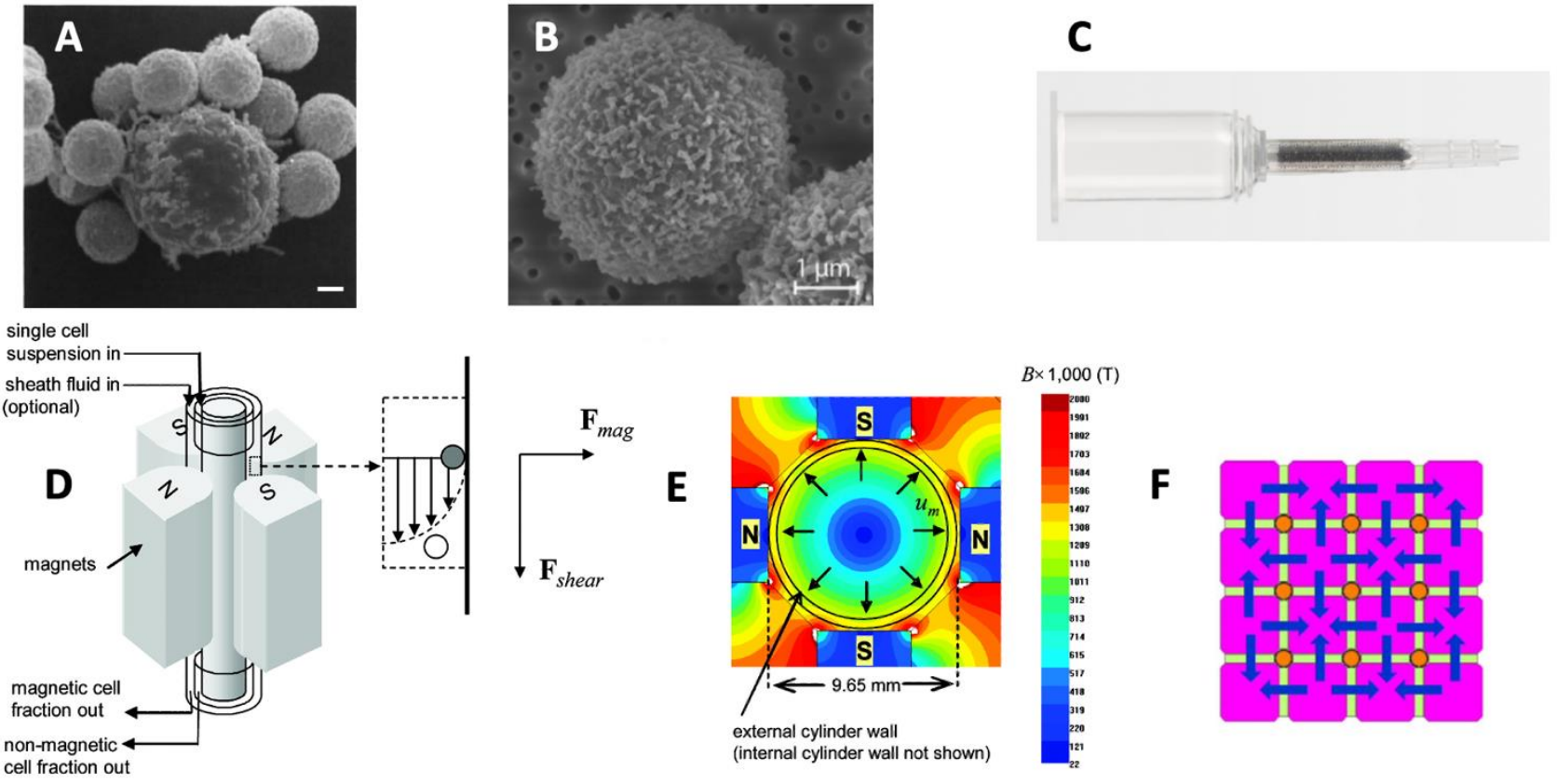

E

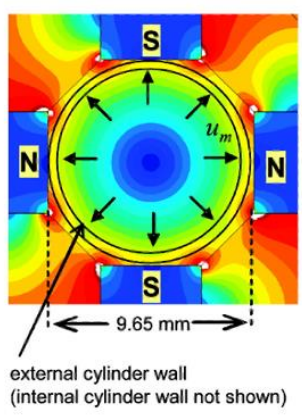

$B \times 1,000(\mathrm{~T})$

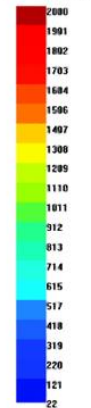

F

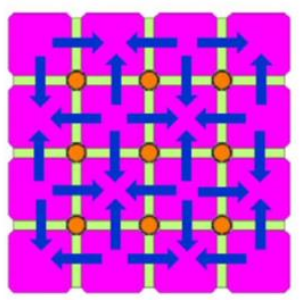

Figure 10. Examples of conventional magnetic particles and separators. (A) H9 lymphocyte infected with HIV-1 labeled with Dynabeads $(2.8 \mu \mathrm{m}$ in diameter) coated with anti-p-18 (scalebar: $1 \mu \mathrm{m})$. Reprinted with permission from [163]. (B) Human PBMCs labeled with MACS CD3 MicroBeads $(50 \mathrm{~nm}$ ) for the isolation of T cells (source: https://www.miltenyibiotec.com, accessed on 10 December 2021). (C) Example of dedicated column used with HGMS (large cell column, source: https:/ / www.miltenyibiotec.com, accessed on 10 December 2021). (D,E) Schematics of a quadrupole magnetic cell sorter and corresponding magnetic field intensity in the radial direction. Adapted with permission from [6]. Copyright (c) 2011, American Chemical Society. (F) Tessellated permanent magnet circuits for flow-through, open-gradient cell separation (9-channel array). Light rectangles, pink areas and orange circles, respectively, represent permanent magnet blocks, soft steel yokes and flow channels. Adapted with permission from [162]. Copyright (c) 2016 Elsevier B.V. 


\subsection{Microfluidic Cell Separators}

Due to progress in miniaturization processes, microfluidic devices have been widely used for a wide range of applications, in particular, for biological research or biomedical applications. They can handle small-volume samples, which provides several benefits (e.g., reduced cost of reagents, increased chemical reactivity, laminar fluid flow, etc.), including the ability to bring the magnets closer to the micrometric channel in which the samples will flow. Microfluidic cell separation can rely on various strategies to generate a nonuniform magnetic field, to create a MAP force that can be either perpendicular or parallel to the flow and exploit it to trap or deviate specific cells from the sample into a dedicated buffer. This force can also be combined with other effects (e.g., specific design of the microfluidic channel or additional flow or force) to enhance separation efficiency. An exhaustive overview of these different strategies is given in some recent reviews [25,164]. One strategy concerns electromagnets of different designs, such as single wire or microcoils. They enable generation of a dynamically configurable magnetic field (ON/OFF) but have the disadvantage of generating Joule heating that can be detrimental to cells. We will, therefore, here focus on two other common approaches based on permanent magnets or ferromagnetic materials.

\subsubsection{Permanent Magnets}

The first and easiest strategy consists in using a macroscale permanent magnet placed on the side of a microchannel and exploiting the non-uniformity of the magnetic field at the edge, as illustrated on Figure 11A. Cells will be more or less deflected from their laminar flow path according to their magnetic properties, which enables their sorting, and potentially transfer of target cells in another fluid [77]. The arrangement of several permanent magnets of different magnetization orientations expands the possibilities of this strategy, as in the Halbach configuration (Figure 11B) [71,165] strengthening the magnetic field on one side of the magnets. Alternatively, magnets arranged with opposing poles enable a large magnetic field gradient to be obtained. Placed underneath the chip, such magnet assembly ensures target cell trapping at the bottom of the microchannel (Figure 11C) [166]. Similarly, Dumas Bouchiat et al. have developed an array of oppositely magnetized micromagnets capable of producing magnetic field gradients as high as $10^{5} \mathrm{~T} / \mathrm{m}$, obtained by thermomagnetic patterning of a flat $\mathrm{NdFeB}$ hard magnetic film [167], which can be integrated at the bottom of a microfluidic channel [44,168] (Figure 11D). Creating higher, asymmetric [169] gradient magnetic fields and forces, locating the maximum flux density at the center of the channel $[170,171]$ (Figure 11E) or at multiple spots [172], are different options provided by adequate arrangement of several magnets, including the quadrupole magnet arrangement mentioned earlier in Section 4.1.

In order to limit the influence of cell sedimentation caused by gravity that could restrict the purity of the targeted sample, the permanent magnet can also be placed on top of the microfluidic device [173]. The use of bulk magnets may be combined with channel structuration. In this way, the trapping areas are not solely determined by the magnetic field applied, but also by the channel microstructures. For instance, by adding a microwell array between the channel and magnet, Huang et al. could demonstrate that MNP-labeled CTCs were trapped in the microwell region near the edge of the magnet after a high-speed washing step, while uncaptured blood cells could be easily flushed away [173]. Channel microstructures enable creation of passive turbulence/vortexes and increase the probability of interaction between target cells and the trapping surface due to advective transport [174,175] (Figure 12A). Zhang et al. [176] exploited this effect to first trap anti-EpCAM conjugated magnetic beads in a herringbone groove by applying the magnetic field and then introducing cells in the microfluidic device with a precise infusion rate for immunoreaction. However, owing to the fragility of some biological cells, such as CTCs, this sharp groove pattern was smoothed into a wavy herringbone pattern to avoid physical damage to the cells [177] (Figure 12B). Yang et al. recently developed a cell-sorting system that combines the mechanisms of magnetic sorting, with an array of micropillars 
acting as a sifter [178]. The device is capable of separating target cells, background cells and redundant MNPs at the same time (Figure 12C).
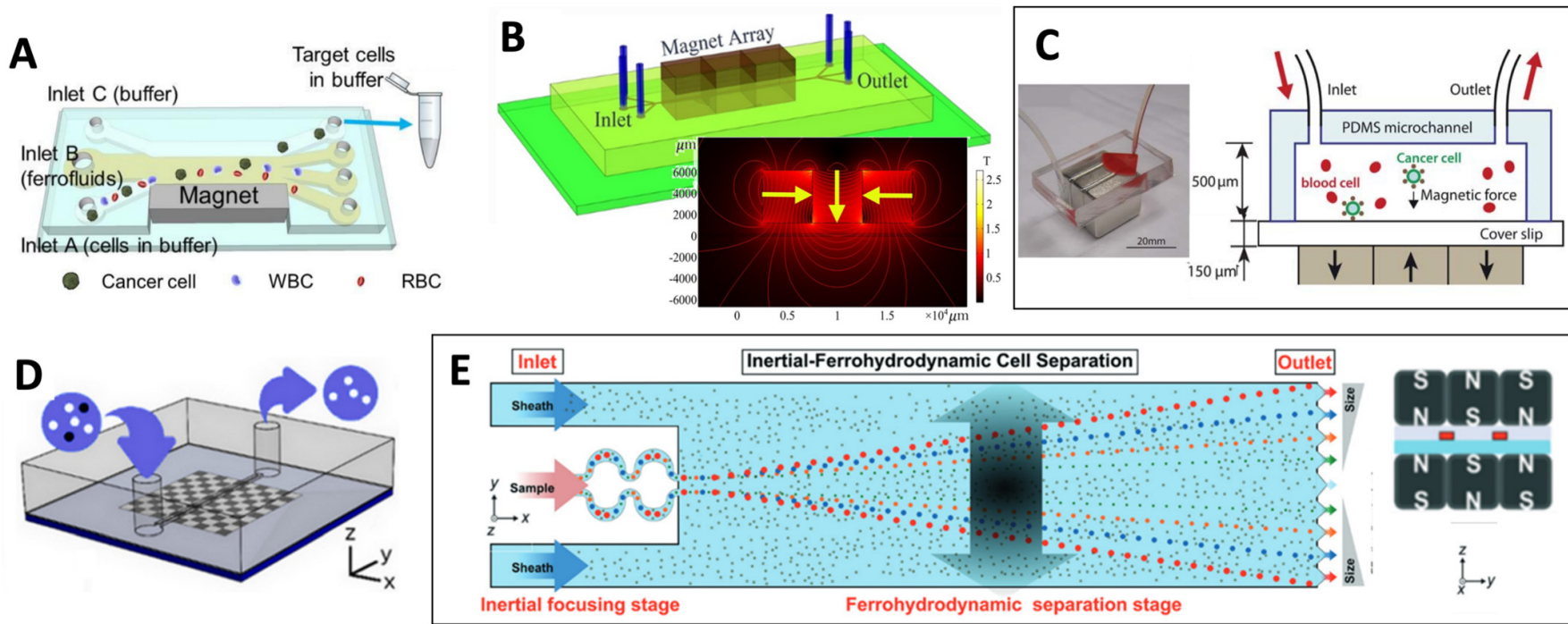

Figure 11. Macroscale permanent magnets in microfluidic separation devices. (A) Illustration of a simple magnet separation device exerting a negative magnetophoretic force on CTCs and WBCs and a positive force on RBCs in a ferrofluid. Reprinted from [77], with the permission of Royal Society of Chemistry; permission conveyed through Copyright Clearance Center, Inc. (B) Illustration of Halbach configuration; distribution of the magnetic field from one side to farther distances. Reprinted with permission from [71]. Copyright 2020 American Chemical Society. (C) Picture (scale bare is $20 \mathrm{~mm}$ ) and schematic illustration of a microfluidic device with three magnets with opposite polarities placed under the channel for CTCs isolation. Reprinted from [166], with the permission of Royal Society of Chemistry; permission conveyed through Copyright Clearance Center, Inc. (D) Illustration of an array of micromagnets obtained by thermomagnetic patterning of NdFeB hard magnetic film. Reprinted from [167], with the permission of AIP Publishing. (E) Schematic of inertial-ferrohydrodynamic cell separation. Six magnets, placed above and below the channel, create a maximum flux density at the center of the channel. Reprinted from [170] with the permission of Royal Society of Chemistry; permission conveyed through Copyright Clearance Center, Inc.

A

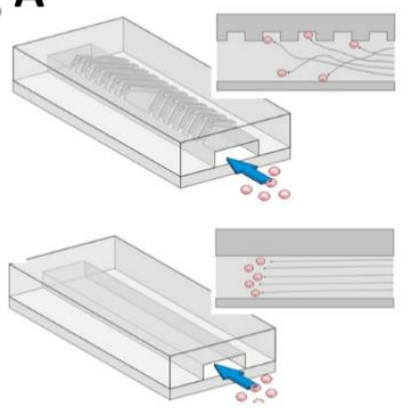

B

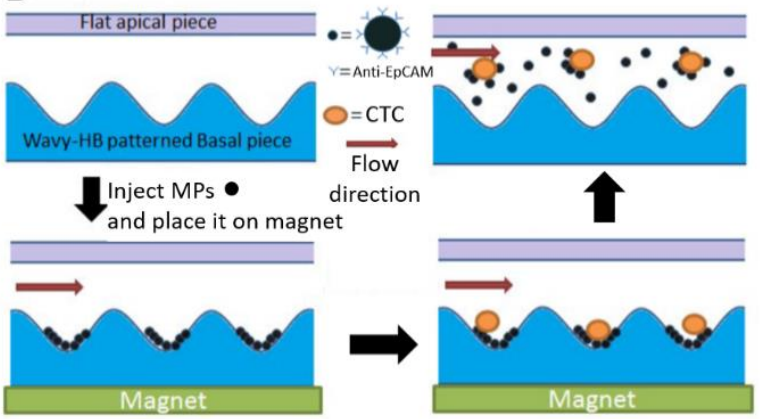

C

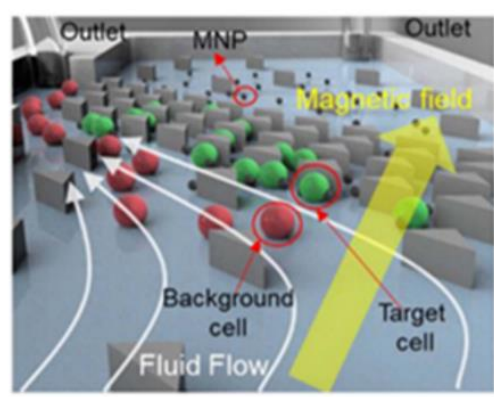

Figure 12. Macroscale permanent magnets combined with microstructured channels (A) Principle of advective transport with herringbone pattern. Reprinted from [174]. (B) Schematic of the principle of CTCs trapping in wavy herringbone. Reprinted from [177] with the permission of Royal Society of Chemistry; permission conveyed through Copyright Clearance Center, Inc. (C) Schematic of magnetic labeled cell trapping in a micropillar array. Reprinted with permission from [178] @ IOP Publishing. 
Permanent magnets can also be fabricated using hard magnetic powders, such as $\mathrm{NdFeB}$, embedded in a polymer matrix $[179,180]$. The most used polymer is PDMS. Such composite materials featuring magnetic properties can be easily structured using simple, soft lithography processes, which facilitate the integration of magnetic sources very close to the microfluidic channel. They therefore provide a promising low-cost alternative to complex and costly microfabrication approaches, as recently reviewed [181].

\subsubsection{Soft Magnetic Materials}

A second strategy is to concentrate the magnetic flux relying on soft ferromagnetic elements embedded close to the microchannel and magnetized with an electromagnet or macroscale permanent magnet. This solution creates the possibility of switching off the magnetic field to release the trapped cells. The external magnet does not need to be as close to the channel as in the previous strategy, which can be more convenient for microscopic observation. Due to the development of easily accessible and cost-affordable microfabrication techniques, such as nickel electroplating [182], the ferromagnetic material can advantageously be microstructured to increase the magnetic field gradient. Such a high-gradient magnetic field concentrator can thus be integrated close to the microfluidic channel so that molecules and living cells bound to magnetic particles are pulled from one laminar flow path to another by applying a local magnetic field gradient [183].

Inglis et al. developed a microfluidic device with tilted strips of $\mathrm{Ni}$ at the bottom surface of the microchannel [184] to generate a lateral force evenly over the whole microchannel and deviate cells from their laminar trajectories. Such lateral-driven magnetophoretic separation was also implemented with a ferromagnetic wire array to separate blood cells based on their native magnetic properties [185]. More recently, Kim et al. developed a single-cell isolation technique for CTCs based on a similar approach [186]. Their device comprised a lateral magnetophoretic microseparator and a microdispenser as a two-step cascade platform. After CTCs enrichment from whole blood by the lateral magnetophoretic microseparator, target cells were electrically identified with a single-cell impedance cytometer and isolated relying on a synchronized microshooter (Figure 13A). For their part, Aldridge et al. [187] developed a "prismatic deflector" separating a continuous sample stream into discrete subpopulations based on surface marker expression (Figure 13B). Cobalt-based deflection guides made up of distinct segments of different angles can separate cells according to the number of magnetic beads attached to them. Profiling surface marker expression is therefore possible if this magnetic load varies in direct proportion with protein expression, which implies the use of magnetic nanoparticles rather than micrometersized particles. 


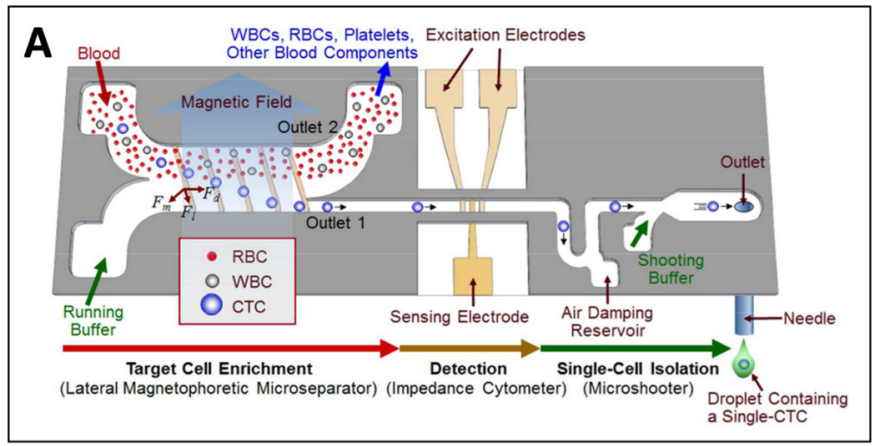

B
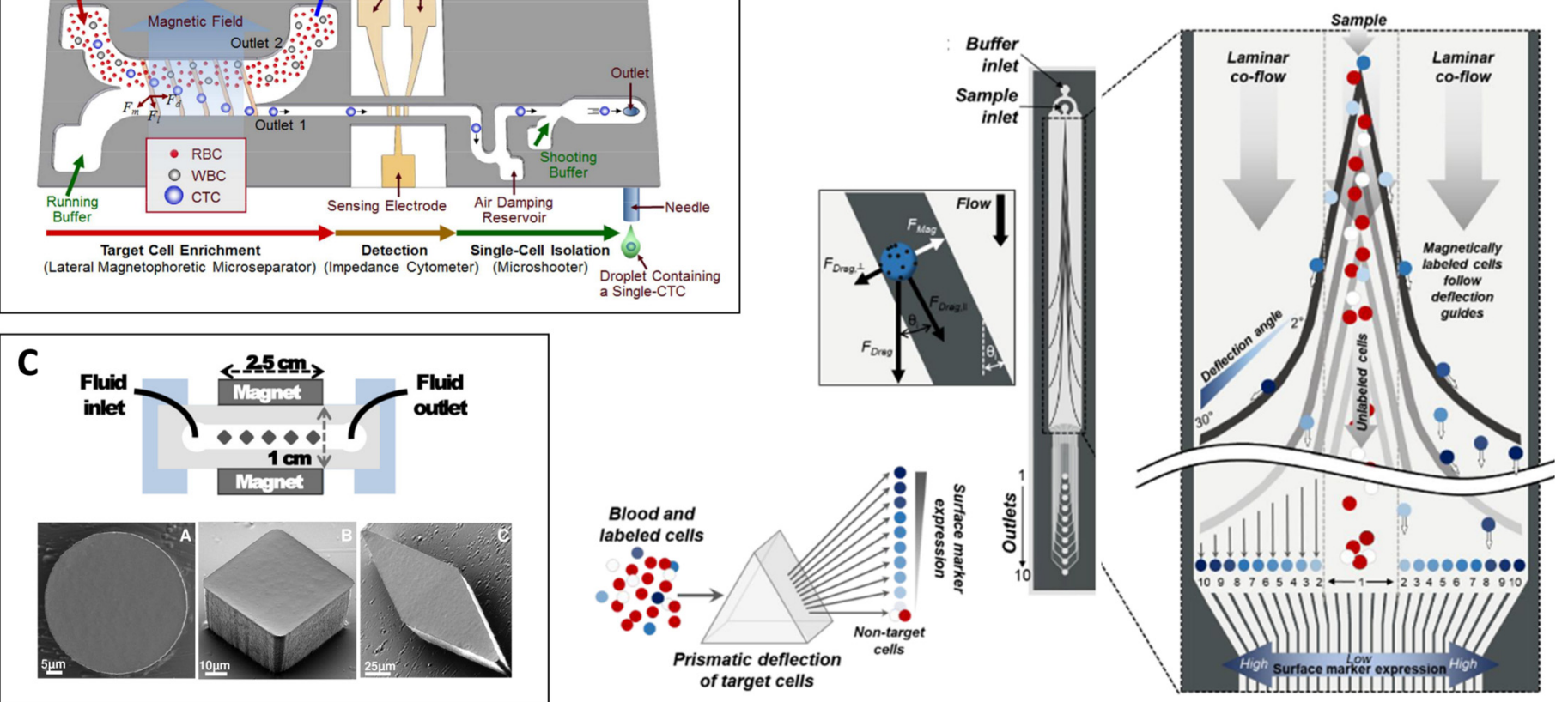

Figure 13. Microfluidic devices with soft-patterned ferromagnetic structures. (A) Two-step cascade platform: Lateral magnetophoretic separator and a microdispenser synchronized with electrical impedance detection. Reprinted with permission from [186]. Copyright 2016 American Chemical Society. (B) Prismatic deflection based on surface marker expression. Reprinted with permission from [187]. Copyright 2018 American Chemical Society. (C) Schematic top view of a microsystem integrating soft iron-PDMS pillars in the channel and scanning electron microscope images of the magnetic structures. Reprinted from [188], with the permission of AIP Publishing.

Along with microwells strategies presented earlier, arrays of microstructured ferromagnetic material (such as pillars or planar magnets), magnetized by permanent magnets, have also been implemented to provide local magnetic field enhancement at specific locations in the microfluidic channel, where target cells are trapped. These structures therefore act as a magnetic sifter [189]. The use of soft micro or nanoparticles (carbonyl iron or nickel, for instance) embedded in a polymer matrix can provide a simple way to integrate soft magnetic pillars into the microfluidic channel (Figure 13C). Self-assembled structures of magnetic microparticles on top of printed magnetic ink spots also offer the potential to reduce the complexity and cost of fabrication of soft magnetic structures; this method is applicable for low flow rates to prevent the detachment of self-assembled structures from the printed arrays [190].

Unlike the majority of devices based on soft lithography, Malic et al. [191] developed a microfluidic separator composed of a sandwich of thermoplastic layers fabricated using hot-embossing. A hard plastic layer contains the engraved 3D magnetic capture region, and the microfluidic interface is embossed in a softer layer. Two permanent magnets are placed on both sides of the device, to generate a quasi-uniform magnetic field within the chamber and $16-\mu \mathrm{m}$ diameter pillars are coated with a soft magnetic material $(2 \mu \mathrm{m}$-thick Ni layer). To minimize the physical damage to the cells due to collision with the pillars, Huang et al. [192] have decreased the thickness of the micromagnets, made of Ni patterned into spots, using lift off and thermal deposition. Darabi and Guo proposed a continuous flow system based on a similar principle, enhanced with a buffer switching scheme to improve the performance of the separation process [193].

Besant et al. improved this concept of pillars trapping by giving an X-shape to the extruded microstructures which created pockets of locally low linear velocity, named velocity valleys [194]. Cells that enter a velocity valley slow down, allowing the magnetic 
force to overcome the reduced drag force and trap them. The cell-sorting device with four zones of decreasing average linear velocity is represented on Figure 14A. As the channel cross section is increased, the drag force drops in each sequential zone. Cells with higher levels of surface markers are captured in the first zones while cells with lower levels are captured in the latest. Here, the capture structures (pillars or X-shape) generally span the full height of the channel in each zone, but due to the reduction of the drag force the mechanical stress imposed on the cells is reduced. Poudineh et al. have developed a similar procedure [195] to profile nanoparticle-labeled cells, exploiting a concept referred to as "magnetic ranking cytometry" (MagRC). Using antibody-functionalized magnetic nanoparticles, cells can be discriminated thanks to their magnetization that is proportional to surface expression of a selected biomarker, as mentioned earlier. To do so, round nickel micromagnets are patterned under the X-shaped structures within the channel to increase the external magnetic field. As the micromagnets increase in size along the length of the channel, cells with a lower level of surface marker expression are trapped (cf. Figure 14B).
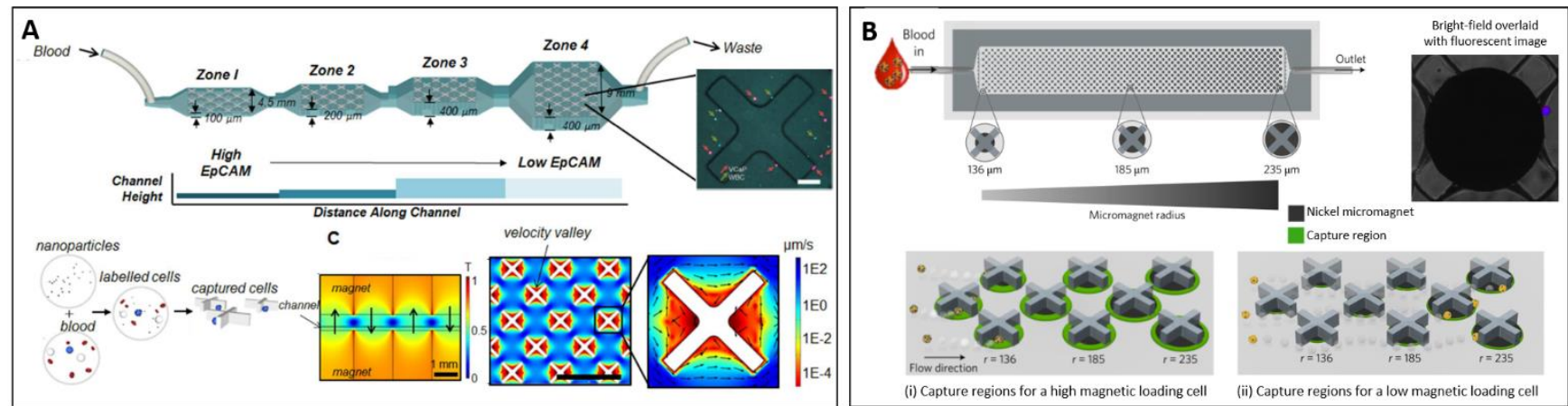

Figure 14. X-shaped velocity valleys. (A) Schematic of the velocity valleys principle. Magnetic field and flow velocity distributions in the channel (scale bar represents $1 \mathrm{~mm}$ ). Fluorescent microscopy picture with CTCs in red (the scale bar represents $150 \mu \mathrm{m}$ ). Reprinted (adapted) with permission from [194] (B) Velocity valleys enhanced with Ni structure (microscope image of captured immunostained SKBR3 cell). Reprinted by permission from Springer Nature-Nat. Nanotechnol. [196], Copyright 2017.

\subsubsection{Hybrid Integrated Strategies}

As previously seen, several studies show the value of integrating particular geometries in the channel to combine hydrodynamic effects with separation based on magnetophoretic properties (e.g., grooves [175,176], channel enlargement [194], sheath flow [152,170], etc.). Other passive methods can also be integrated to further increase separation efficiency and throughput. Nasiri et al. [197] proposed a hybrid device including inertial separating and focusing channels, and a magnetic cell separation device for CTC separation from whole blood based on specific antigen properties, to improve the separation efficiency and purity of separated CTCs (Figure 15A). In a similar manner, Ozkumur et al. [198] exploited a focusing unit with an upstream deterministic lateral displacement module, in which cells navigate through an array of posts. The post design ensures that small cells move with the convective flow while larger cells move in a direction imposed by the array. Based on this principle, RBCs and platelets stayed in the original blood sample, while large WBCs and target CTCs were transferred, then focused, into a specific buffer for antigen-dependent magnetophoretic sorting (Figure 15B). The device has the advantage of enabling both positive and negative selection modes. 

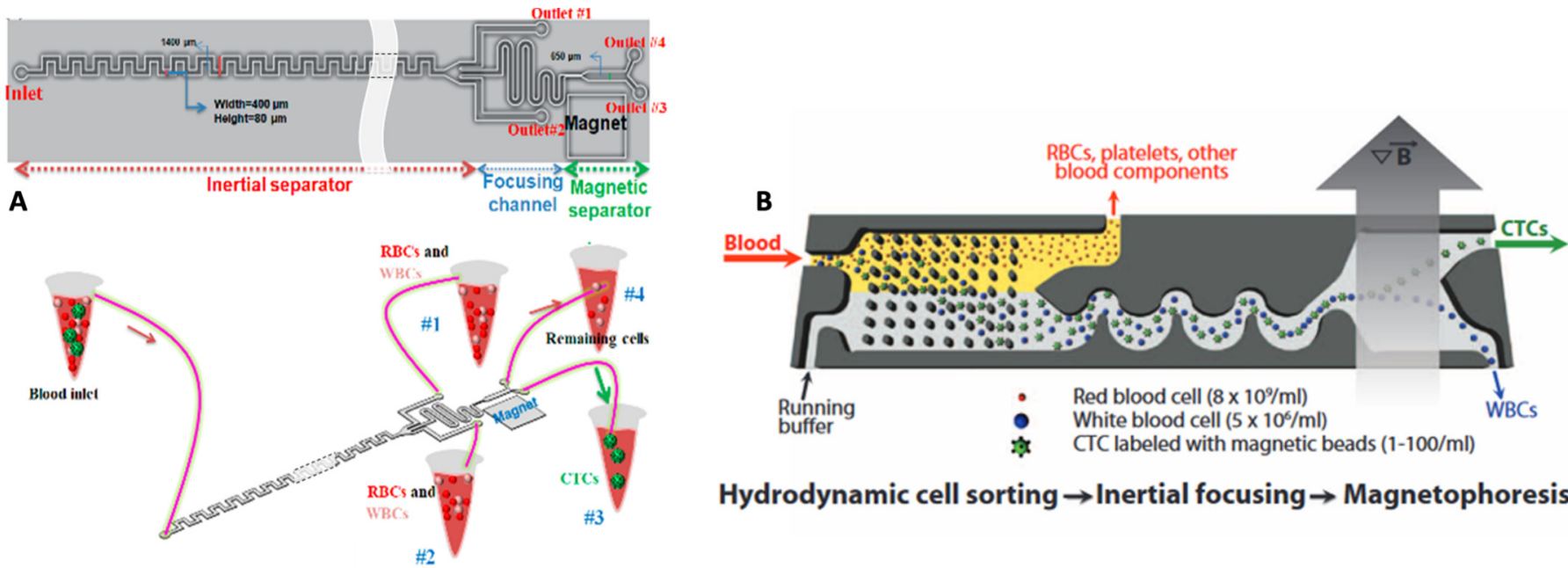

Hydrodynamic cell sorting $\rightarrow$ Inertial focusing $\rightarrow$ Magnetophoresis

Figure 15. Magnetophoretic separation devices combined with passive hydrodynamic functions for CTCs isolation (A) Inertial (not at scale) and magnetophoretic combined separators [197] (B) Hydrodynamic cell sorting (deterministic lateral displacement) and inertial focusing combined with magnetophoretic sorting. Reprinted from [198] with permission from AAAS.

Magnetophoresis can also be combined with other physical methods, such as centrifugation [81,199], acoustophoresis [200], or dielectrophoresis [152,201] in hybrid microfluidic devices. This approach provides increased flexibility by exploiting different cell characteristics, such as density, compressibility or electrical properties, and opens the way to multi-target cell separation. Kim et al. [201] combined, for instance, DEP and MAP in the same device and demonstrated high-purity sorting of multiple bacterial target cell types in a single pass. The target cell types were sorted based on surface markers, via specific receptor-ligand binding to either DEP or magnetic tags. More recently, Shamloo et al. [152] have investigated a combined dielectrophoresis and magnetophoresis separator based on cell intrinsic properties. Their two-step device (Figure 16A) is designed to first remove the largest part of a blood sample (i.e., RBCs and smaller platelets), in the magnetophoresis section. Remaining cells are then sorted by the dielectrophoretic force depending on their dielectric properties and diameters.

Shamloo et al. [81,202] have also presented a system mounted on a rotating disk, where centrifugal force is combined with the negative magnetic force to enhance both purity and recovery rate of low-concentrated target cells. As illustrated on Figure 16B, sample preparation is performed directly on the chip, where the blood sample and ferrofluid are mixed using magnetic force. After that, cells are aligned after passing through a pinched channel and sorted with both negative magnetophoretic and centrifugal forces in a curved channel.

Bhaghat et al. [200] have recently described a novel approach combining immunomagnetic depletion and acoustic cell sorting (Figure 16C). The sample first passes through a magnetic depletion step that removes $>98 \%$ of unwanted blood cells labeled with magnetic microparticles and then undergoes an in-line acoustic focusing and washing step, which removes unwanted cells and concentrates the CTCs for sorting. 

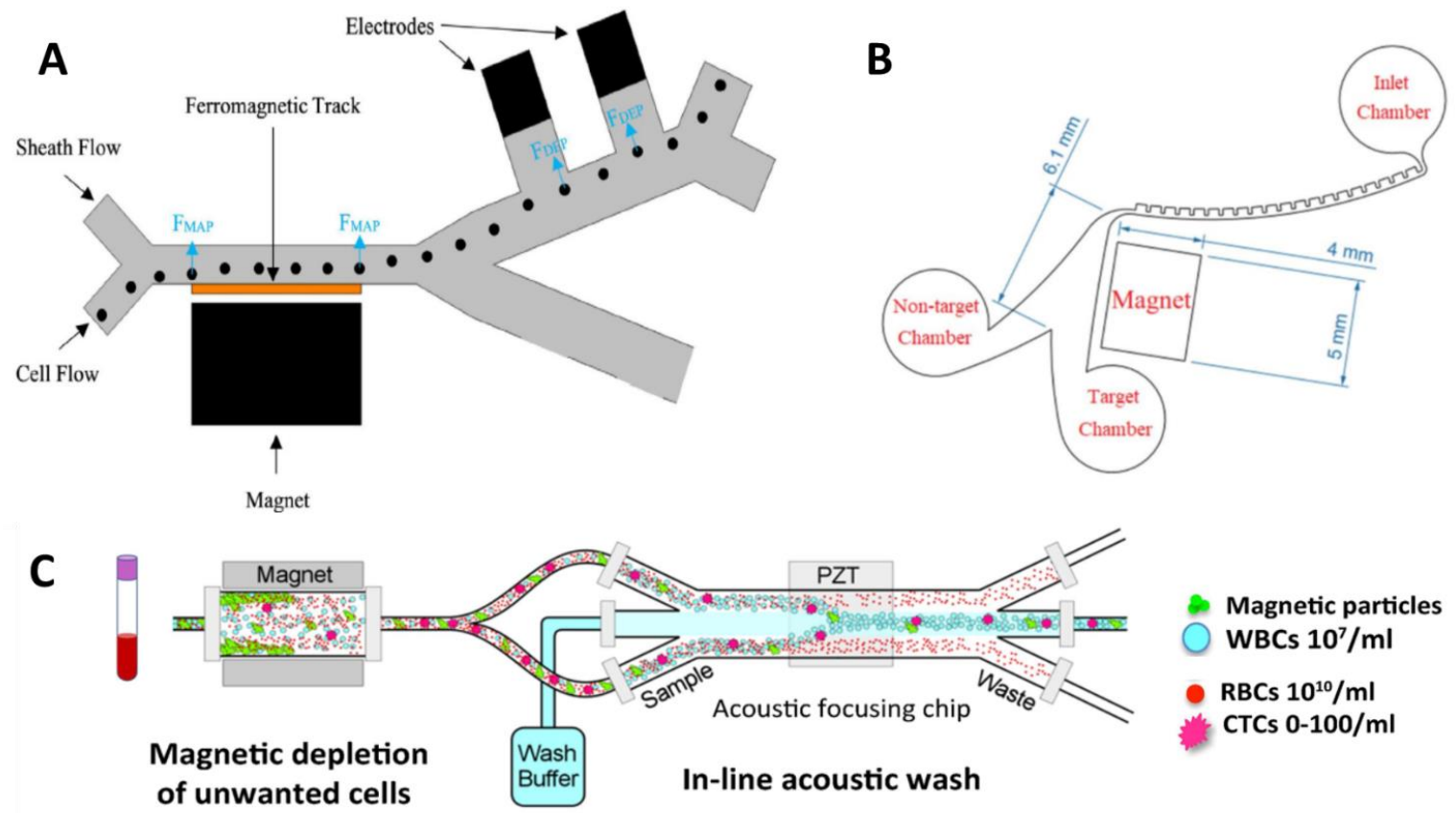

Figure 16. Illustrations of cell separators combining MAP with other forces. (A) A combined dielectrophoresis and magnetophoresis separator based on cell intrinsic properties. Reprinted from [152]. (B) Centrifugal microfluidic platform using hydrodynamic and magnetophoretic techniques, reprinted from [202]. (C) Approach combining immunomagnetic depletion and acoustic cell sorting. Reprinted from [200].

\subsubsection{Fluidized Bed Separation}

A fluidized bed consists of a granular solid phase that behaves like a fluid when the drag force due to an imposed vertical fluid flow is higher than an opposite gravitational force. Used in chemistry and biology for many applications, it has been implemented by Pereiro et al. [203] in a miniaturized microfluidic device where gravity is replaced by a magnetic field created by an external permanent magnet. The granular solid phase is composed of magnetic microparticles (diameter ranging from 1 to $5 \mu \mathrm{m}$ ) that are functionalized so that they can specifically capture species that are brought by the flow (Figure 17). The authors highlight that stability, resistance to clogging and ability to separate analytes from a liquid, coupled with a very low elution volume, make this system very promising to play the role of a pre-concentrator in microsystems.
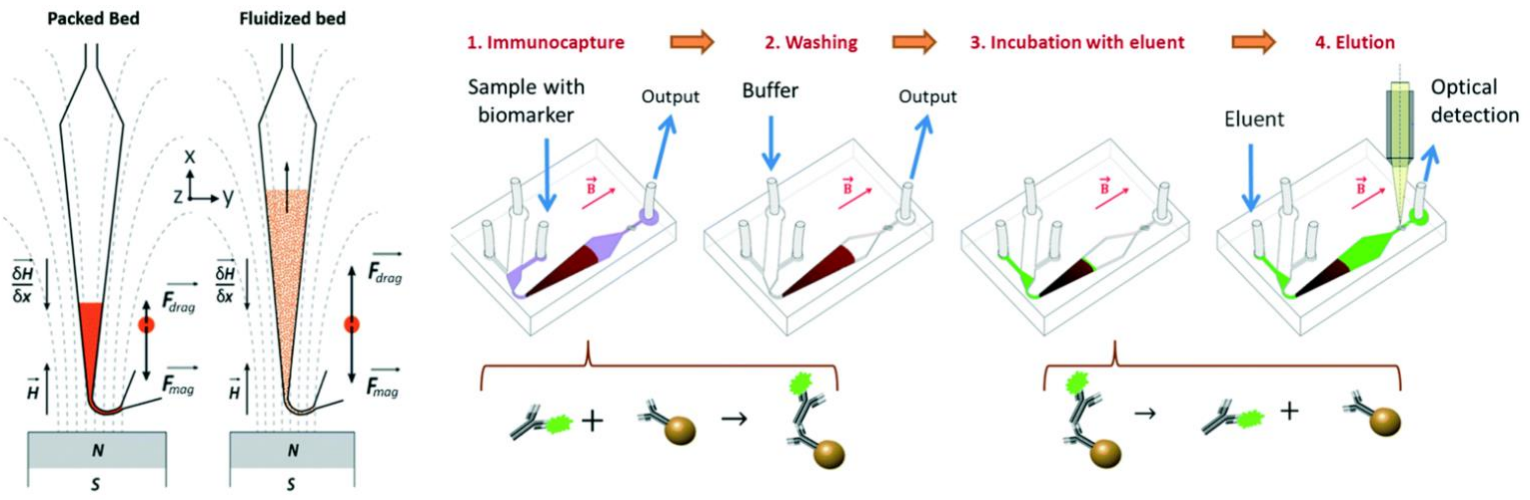

Figure 17. Schematic illustrations of the microfluidic fluidized bed for two working regimes: at low imposed pressure, particles are organized in a packed bed. When drag forces associated with the flow compensate for magnetic forces, fluidization of particles occurs. The volume of the bed can be 
tuned while maintaining the equilibrium between drag and magnetic forces. On the right, a schematic description of the protocol for the concentration and extraction of a model biomarker by immunocapture followed by elution washing step. Reprinted from [203], with the permission of Royal Society of Chemistry; permission conveyed through Copyright Clearance Center, Inc.

\section{Applications}

Magnetic cell separation is used for a wide range of applications and in various contexts, such as disease diagnostics, environment monitoring, fundamental biological research, etc. It is a crucial step in diverse biosensor assays and, along with the development of new cell separation systems, lots of efforts are also devoted to the synthesis of multifunctional magnetic nanoparticles displaying fluorescent [204-207], electrochemical [208,209] or plasmonic $[210,211]$ properties, to enable both magnetic capture and downstream detection. In this section, we present examples of applications with a particular emphasis on CTCs and pathogenic bacteria isolation, representing considerable research efforts from the community.

\subsection{Circulating Tumor Cell (CTC) Isolation}

CTCs are defined as cancer cells that detach from a solid tumor lesion and enter the bloodstream, thereby having the potential of colonizing vital distant organs. They are of paramount importance to understand the biological process of metastasis and constitute potential blood-based markers to non-invasively evaluate disease progression and monitor therapeutic response. A significant effort has therefore been made in recent years to develop specialized technologies to capture, enumerate and interrogate CTC populations to test their suitability for clinical applications [212], as recently reviewed by others [213-217]. The low frequency of CTCs (potentially less than 1 CTC per mL of blood [218]), together with their heterogeneity and their property of moving individually or as cell clusters, make their detection very challenging [219].

\subsubsection{Commercial Systems}

The gold standard for the enumeration of CTCs remains the CellSearch ${ }^{\circledR}$ system (Menarini Silicon Biosystems, Huntington Valley, PA, USA), based on magnetic cell separation [220]. It was cleared by the US Food and Drug Administration (FDA) in 2004 as a diagnostic tool to predict survival in patients with metastatic breast cancer [221], and was since FDA-approved for prognostic use in prostate and colorectal cancer. The method is based on magnetic enrichment of CTCs from a $7.5 \mathrm{~mL}$ blood sample using ferrofluid nanoparticles with antibodies targeting epithelial cell adhesion molecules (EpCAM). Cells are also fluorescently stained with antibodies against cytokeratins $(8,18,19)$ and CD45 antigen, respectively, specific to epithelial and white blood cells. The system detects and enumerates CTCs of epithelial origin (CD45-, EpCAM+, and cytokeratin 8, 18, 19+). However, as CTC detection relies on epithelial markers, the system fails to detect populations of CTCs with low EpCAM level expression and non-epithelial phenotypes, such as carcinoma cells, that undergo epithelial-mesenchymal transition (EMT), or CTCs of mesenchymal origin [222-226]. Elimination of residual leukocytes using immunomagnetic capture antibodies against the leucocyte marker CD45 can also be performed after tumor cell enrichment by other approaches, such as filtration with the ISET ${ }^{\circledR}$ system [227]. Another commercial platform for CTC detection is the AdnaTest (Quiagen), based on positive immunomagnetic selection of cells using a cocktail of antibodies (e.g., EpCAM, MUC-1, Her2) specific to the cancer type prior to analysis of tumor-associated gene expression by RT-qPCR [228,229].

\subsubsection{In Vivo Solutions}

The CellCollector ${ }^{\mathrm{TM}}$ developed by Gilupi is a CE-certified medical device able to capture CTCs in vivo directly from the bloodstream, to increase the volume of blood that can be sampled (Figure 18A). EpCAM-positive tumor cells are attached to anti-EpCAM antibodies bound to the surface of a wire inserted into a vein. The wire is stained with 
fluorescently labeled antibodies and examined microscopically to identify CTCs [230]. Vermesh et al. have also recently proposed another in vivo solution for intravascular retrieval and enrichment of CTCs. The flexible MagWIRE, composed of magnetic units with alternating polarity, is introduced through an intravenous catheter to efficiently capture targets that have been labeled in the blood with injected antibody-coated magnetic particles (Figure 18B). In a proof-of-concept experiment in a live porcine model, the wire achieved capture efficiencies that corresponded to enrichments of 10-80 times the amount of CTCs in a 5-mL blood draw [231].

\section{A}

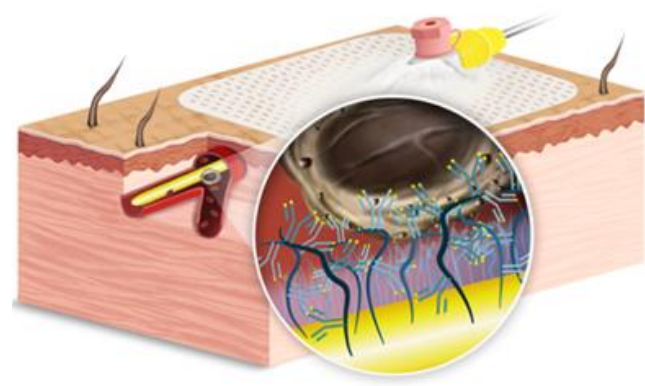

B

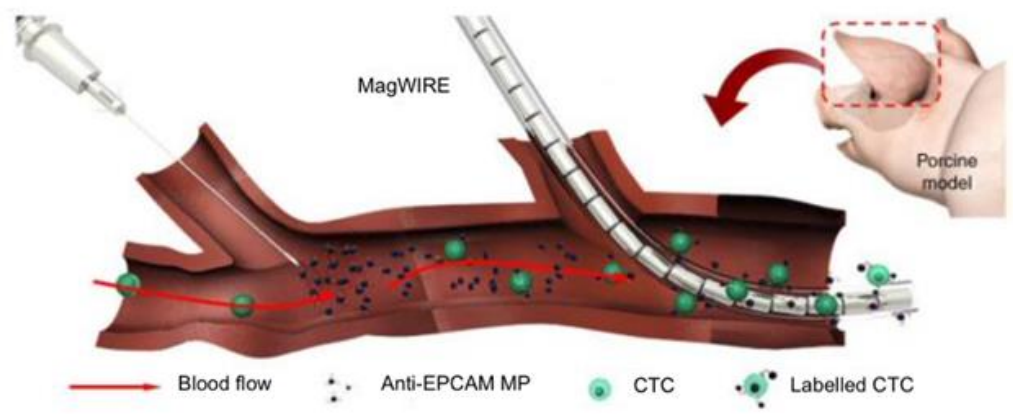

Figure 18. In vivo solutions for CTC isolation. (A) Blood screening with the CellCollector ${ }^{\mathrm{TM}}$ for in vivo CTC capture (https: / / gilupi.com, accessed on 10 December 2021) (B) Capture of CTCs with the MagWIRE producing high magnetic gradients for efficient cell recovery. Reprinted from [231] with permission form Springer Nature.

\subsubsection{Microfluidics-Based Approaches}

In the more widespread case of in vitro CTC capture, microfluidics-based approaches offer an attractive alternative to macroscale techniques, such as bulk magnetic sorting, since they are operator-independent and have the potential to provide precise sorting conditions and continuous sample processing, minimizing rare cell loss. Thus, many efforts have been devoted to the development of microfluidic systems based on magnetism to isolate CTCs in the past decade [110,177,232-234], as recently reviewed by Chen et al. [235]. The IsoFlux System (Fluxion Biosciences Inc, South San Francisco, CA) is an example of microfluidics-based technology using IMS and dedicated to CTC isolation brought to the market. The sample passes through a microfluidic device that contains an isolation zone to capture CTCs on the upper surface of the cartridge in an externally applied magnetic field. The roof of the microfluidic channel can be removed from the rest of the cartridge with the CTCs retained on its surface in a droplet of approximately $3 \mu \mathrm{L}$ that can then be directly recovered into a cell lysis buffer for molecular analysis or onto a microscopy slide for further analysis.

The Ephesia cell capture technology uses magnetic particles bearing EpCAM antibodies, self-assembled in a regular array in a microfluidic flow cell [190]. High aspect-ratio magnetic columns are generated using a magnetic field and act as sieves to capture epithelial cells with high specificity and capture efficiency above $90 \%$ for concentrations as low as a few cells per $\mathrm{ml}$, at a throughput of $3 \mathrm{~mL}$ per h [236]. Tang et al. also described an approach based on preliminary bead assembly in which immunomagnetic nanoparticles (IMN) formed patterns between nickel posts electroplated on a transparent (ITO-coated glass) substrate encapsulated in a thin PDMS layer (Figure 19A). CTCs were captured from whole blood on IMN and, as they were trapped almost in the same plane, they could be directly visualized with an inverted fluorescence microscope in situ for identification and enumeration by immunocytochemistry [237]. The capture efficiency could be up to $94 \%$ and the throughput approached $0.5 \mathrm{~mL} / \mathrm{h}$ when four channels were arranged in parallel. This IMS device was later adapted for the development of a novel extracorporeal circu- 
lation microfluidic chip detection system (IV-chip-system), which could realize real-time monitoring of the tumor cells' quantitative changes at different time points [238].

A
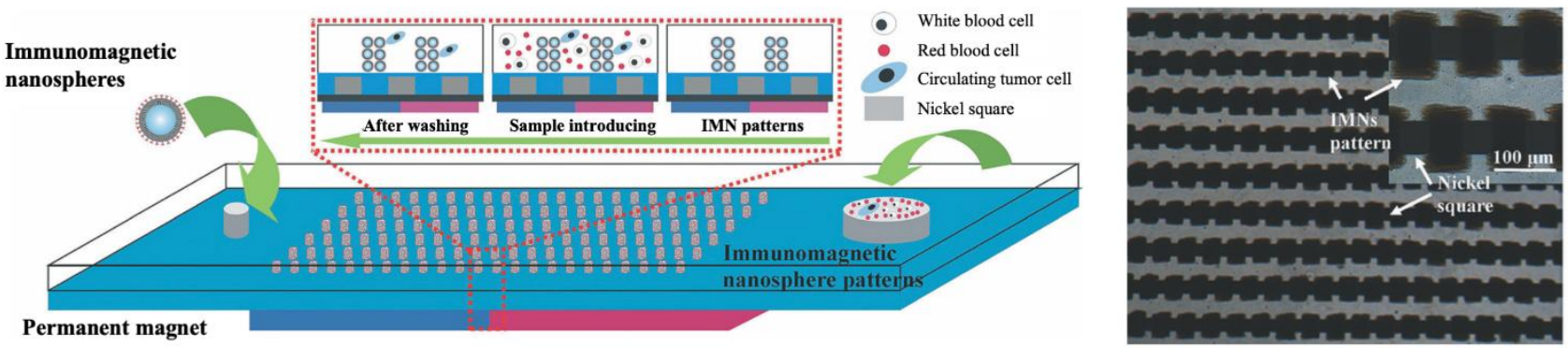

B
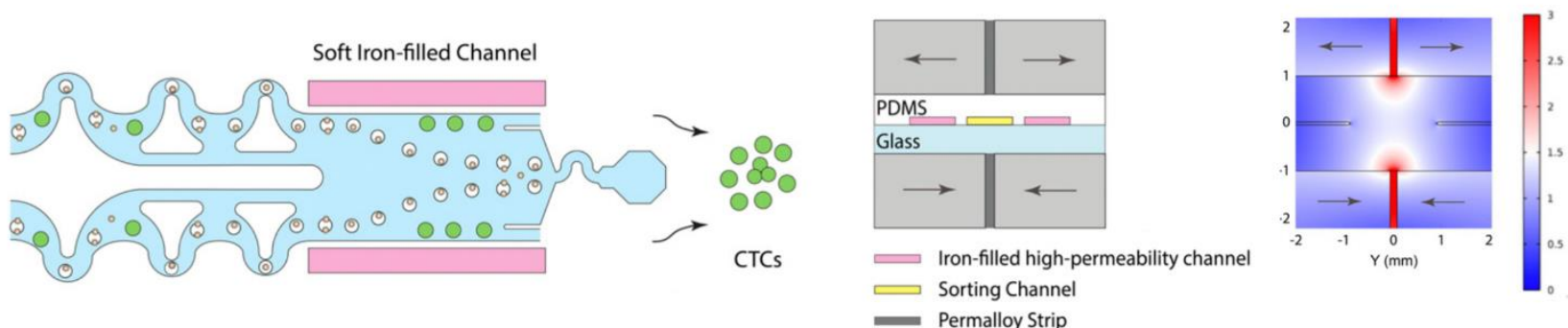

Figure 19. Microfluidic devices for CTC isolation. (A) Schematic diagram of magnetic nanosphere based microfluidic device and microscopic image of IMN patterns and Ni squares in the detection zone. Used with permission of Royal Chemical Society from [237]; permission conveyed through Copyright Clearance Center, Inc. (B) Final separation stage of the ${ }^{\mathrm{LP}} \mathrm{CTC}$-iCHIP, combining a wiggler concentrator for inertial focusing and a magnetic separator (top and cross views). The labeled WBCs are focused by the force towards the center of the channel, where the magnetic field intensity is maximum (right). Reprinted with permission from [171].

Lateral magnetophoresis-based approaches have also been widely reported for continuous separation of white blood cells and CTCs, one of these populations being labeled with magnetic nanobeads for positive or negative isolation of CTCs [186,239]. The advantages of both approaches were evaluated and compared by Cho et al. [240]. They concluded that the positive isolation method could be used to obtain highly pure CTCs, enabling detection of somatic oncogenic mutations using advanced genetic analysis techniques, while negative isolation yielded a larger number of CTCs and was more suitable for discovery of cellular and transcriptomic biomarkers of cancer.

Methods to enrich and count CTCs can be divided into two groups [241], one taking advantage of cell surface markers, including most methods based on magnetism, and the second using physical characteristics of cells, such as size [242], deformability and density [243]. A third, hybrid, strategy can also be used, as with the CTC-iChip technology developed by the Toner group $[171,244]$. The proposed approach relies on negative depletion of leukocytes with antibodies directed against them, which enables isolation of untouched CTCs, without bias for expression of specific tumor epitopes. It is therefore agnostic to cancer type. The separation of labeled leucocytes (WBCs) from unlabeled CTCs follows a first debulking step allowing erythrocyte and platelet depletion using deterministic lateral displacement [244] or inertial separation [245], which are based on cell size differences. Alternatively, it can follow a leukapheresis procedure, allowing centrifugal enrichment of peripheral blood mononuclear cells. Interestingly, the magnetic sorter design has been adapted to deflect labeled WBCs toward the center of the channel in the core of the flow, thus preventing WBCs clogging at high-throughput operation [171]. This was achieved by combining a quadrupolar magnet arrangement with adequate polarity of magnets. Using soft iron-filled channels to act as magnetic microlenses enabled 35-fold increase in the magnetic field gradient and achievement of an ultra-high-throughput (up 
to $168 \mathrm{~mL} / \mathrm{h}$ ). Moreover, $86 \%$ CTC recovery was achieved with a $10^{5}$-fold depletion rate of unwanted cells. The ${ }^{\mathrm{LP}}$ CTC-iCHIP is thus capable of processing an entire leukopak of $\sim 65 \mathrm{~mL}$, and to recover many more CTCs than competing approaches, that can handle only a small percentage of this volume [246] (Figure 19B).

\subsubsection{Towards Point-of-Care Application}

The convenient and noninvasive sampling of CTCs from blood, or "liquid biopsy" offers opportunities for the development of new platforms for point-of-care disease screening [247-249], also accessible in low-resource settings. Yang et al. combined a dual recognition strategy and glucometer-based signal readout to develop a point-of-care approach for detecting CTCs in whole blood [250]. In this research, magnetic beads conjugated with anti-EpCAM antibodies were used as the capture probes for CTC isolation and enrichment, and anti-HER2 antibody and invertase co-modified polystyrene microspheres were used as the signal amplification probes to convert sucrose into glucose, which was then measured by a commercial glucose meter (Figure 20A). Issadore and coworkers have developed a microfluidic chip-based micro-Hall detector ( $\mu \mathrm{HD})$ which can detect single, immunomagnetically tagged cells in whole blood. The $\mu$ HD successfully identified CTCs in $100 \%$ of patients with evidence of clinical progression or stage IV disease, where only $18 \%$ of cases were detected with CellSearch [251,252]. Kirby et al. also developed a lab-on-a-disc platform, which integrates direct immunoseparation of magnetically tagged cancer cells and their detection in whole blood (Figure 20B). Cells isolated from the background sample are specifically directed to a dedicated detection locus and the extent of occupation of this locus is analyzed using bright-field imaging for quantification [199]. The low complexity of this system makes it well suited for use in POC. However, the sample volume processed here is only a few $\mu \mathrm{L}$. The prerequisite of small sample amount and fast turnaround time for POC applications raises the question of the minimal sample volume required to account for CTC cell rarity. According to Hong and $\mathrm{Zu}$, it could be theoretically reduced to $1 \mathrm{~mL}$ of whole blood if more sensitive and accurate detection methods are developed [253].
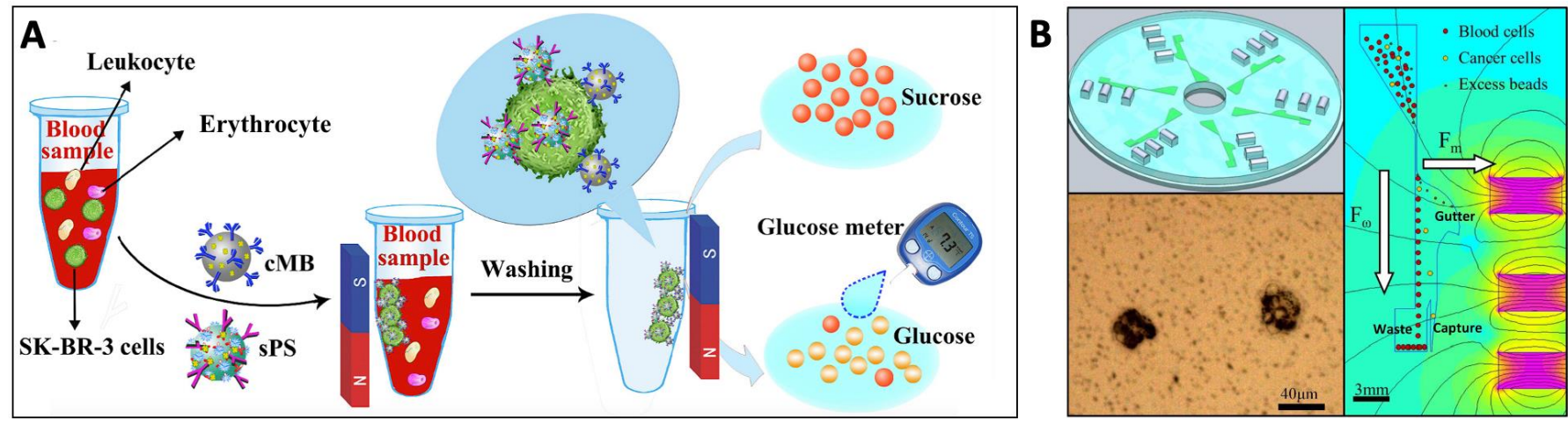

Figure 20. Towards POC detection of CTCs. (A) Dual recognition strategy and glucometer-based signal readout for CTC detection in whole blood. Reprinted with permission from [250] (C) 2019 Elsevier B.V. All rights reserved. (B) Lab-on-a-disc platform for separation and subsequent detection of cancer cells using bright-field imaging. Reprinted with permission from [199] @ 2014 International Society for Advancement of Cytometry.

\subsection{Detection of Pathogenic Bacteria}

Bacterial contamination of food, airborne transmission of pathogenic microorganisms to humans from the environment, and healthcare associated infections are major public health issues. Novel methods for the detection of pathogens in the food and beverages industry, environment, or clinics are therefore required to mitigate these threats.

Guidelines for assessing the microbiological safety of food usually state that pathogens such as Salmonella, E. coli O157, Listeria monocytogenes and Campylobacter should be absent in $25 \mathrm{~g}$ of the sample. Conventional methods for the detection of foodborne pathogens are based 
on culturing the microorganisms to increase their numbers to detectable levels. While they are selective, they can be time-consuming (the whole process can require several days) and laborious [254]. Due to the low content of target microorganisms and the possible interference of food ingredients and nontarget flora, the detection techniques must generally be combined with effective sample pretreatment relying on membrane filtration and centrifugation of the sample suspended in liquid medium. Immunomagnetic separation (IMS) offers an alternative by enabling selective separation of target bacteria from the heterogeneous matrix [54,255-257], and IMS-based sample pretreatment can be automated [258]. Thermo Fisher Scientific commercializes bench-top IMS instruments, such as the Dynal BeadRetriever ${ }^{\mathrm{TM}}$, used in combination with Dynabeads ${ }^{\mathrm{TM}}$ specific to Salmonella, Legionella, Listeria, etc. and the Pathatrix ${ }^{\mathrm{TM}}$ system [259]. Captured bacteria are further tested by polymerase chain reaction (PCR) or direct plating. ELISA is also commonly used as an end-detection method [260]. Still, the current detection techniques remain expensive and complex and there is growing interest in the development of fast, simple, and sensitive methods for on-demand and on-site detection of pathogenic bacteria from complex samples. Multifunctional MNPs coated with antibodies are used in a variety of novel biosensor assays for rapid and sensitive detection of foodborne pathogens based on several measurement methods, such as impedance [261,262], surface-enhanced Raman scattering (SERS [263-265], or loop-mediated isothermal amplification (LAMP) [266], potentially achieving limits of detection lower than $10 \mathrm{CFU} / \mathrm{mL}$. Yao et al. developed a biosensor based on impedance which could detect E.coli O157:H7 in milk with a detection limit of $12 \mathrm{CFU} / \mathrm{mL}$ in $2 \mathrm{~h}$ [261].

Aptamers or peptide-modified nanoparticles are widely investigated as an alternative to antibodies for the specific recognition of target pathogenic bacteria in the context of food safety, environmental or medical applications [101,118,267]. Ozalp et al. have demonstrated that the combination of aptamer-magnetic separation and quartz crystal microbalance could be used for rapid and sensitive detection of Salmonella in milk at $100 \mathrm{CFU} / \mathrm{mL}$ [268]. Feng et al. have similarly captured Listeria monocytogenes in food samples using aptamer magnetic capture, prior to detection by LAMP. The reported detection limit was $5 \mathrm{CFU} / \mathrm{mL}$, for a total assay time of $3 \mathrm{hr}$ [269]. Yuan et al. [265] have developed a new assay based on $\mathrm{Fe}_{3} \mathrm{O}_{4}$ particles functionalized with antimicrobial peptides (AMP) [270] for multiple bacteria detection from whole blood using SERS. When different kinds of bacterial pathogens were combined with the SERS tags, differences among their "fingerprints" could be detected (Figure 21). This approach could be potentially exploited to detect bacteria in blood prior to transfusion.

Phage-based detection strategies are also widely exploited in targeting various pathogens [271-276]. Bacteriophages are bacterial viruses that can infect a broad or narrow range of host organisms. Their ability to uniquely identify living bacterial hosts can be used as a means towards using phages as detectors for bacteria [277]. The natural lysis component of the infection cycle can be exploited for DNA release prior to qPCR analysis [278]. Bacterial selection can be achieved using magnetic particles coated with complete phages [279], or phage components, such as cell-wall-binding domains (CBDs), which are recombinant high-affinity domains derived from phage endolysin, an enzyme that hydrolyzes bacterial cell walls [280,281]. Phages only infect viable hosts and therefore overcome a limitation of other detection methods, such as PCR, which are not able to differentiate between viable and nonviable bacterial pathogens.

In the above-mentioned assays, the target bacteria are separated from the background by forming complexes with magnetic particles prior to detection, but this sample pretreatment by IMS generally requires manual handling. Microfluidic platforms have the potential to integrate preconcentration of target bacteria and subsequent detection in the same chip to minimize off-chip sample preparation time and effort [282,283]. Pereiro et al. could perform one-step detection of Salmonella typhimurium in undiluted unskimmed milk using a microscale fluidized bed. Target bacteria were captured on antibody-functionalized magnetic beads retained in a chamber during sample perfusion due to the equilibrium between magnetic and drag forces. Captured cells were then cultivated in situ under nutritious medium perfusion, and their growth induced an expansion of the fluidized bed 
(Figure 22A) The measurement of this expansion allowed quantitative detection down to $4 \mathrm{CFU}$, with a dynamic range of 100 to $10^{7} \mathrm{CFU} / \mathrm{mL}$ in 2 to $8 \mathrm{hr}[284,285]$. In another study, a Salmonella cell capture efficiency of up to $99 \%$ could be achieved, with only $2 \%$ non-specific capture of E.coli using this hand-held device [286]. Guo et al. developed a microfluidic device for the detection of $S$. typhimurium from a bacterial mixture. A first module integrating nickel wires for lateral MAP enabled separation of non-target $E$. coli and immunomagnetically tagged pathogens, which were deflected towards the detection zone. Here, they were trapped between nickel patterns and could be detected by fluorescence after reaction with biotin-antibody and streptavidin-modified quantum dots (Figure 22B) The limit of detection (LOD) obtained in milk was $5.4 \times 10^{3} \mathrm{CFU} / \mathrm{mL}$ [287].

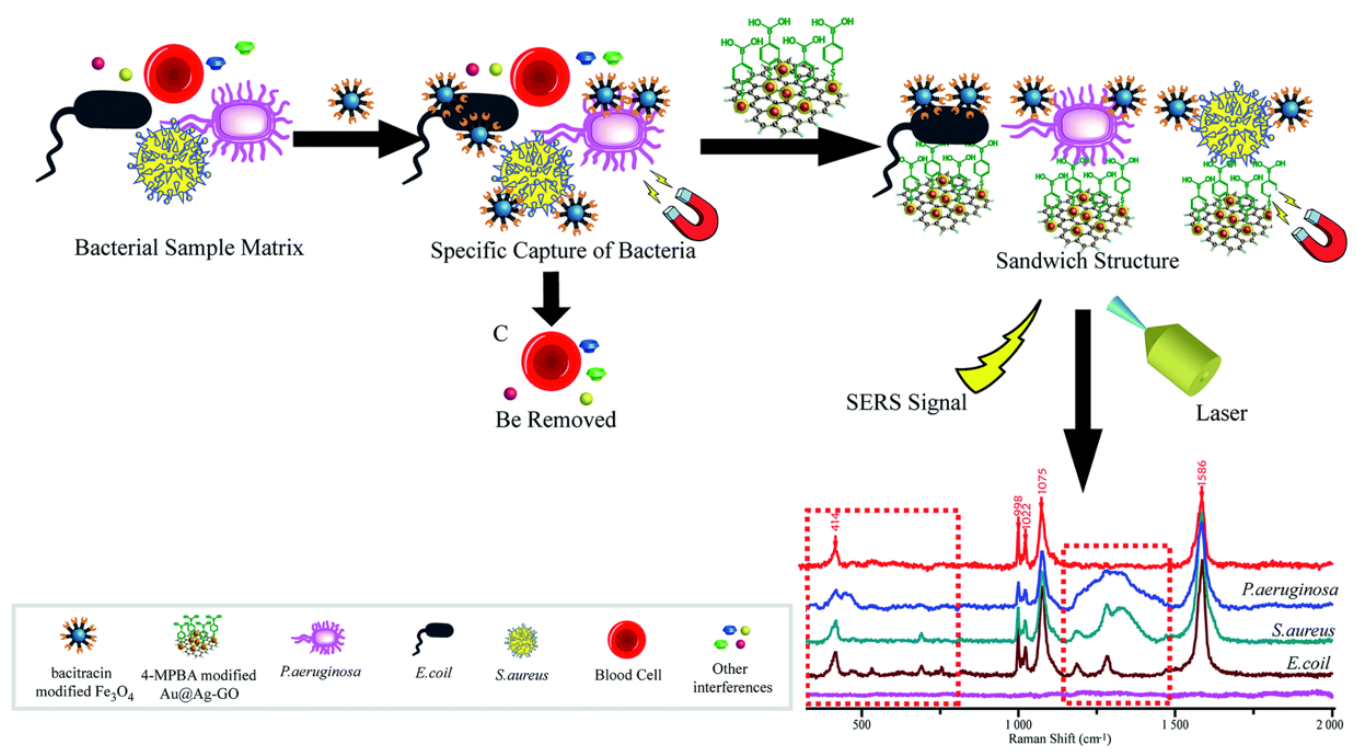

Figure 21. Bacterial detection via a SERS sandwich strategy, in which AMP modified magnetic $\mathrm{Fe}_{3} \mathrm{O}_{4} \mathrm{NPs}$ were utilized in the bacteria capture and 4-MPBA modified Au@Ag-GO nanocomposites were used as SERS tags. Adapted from [266] with permission.
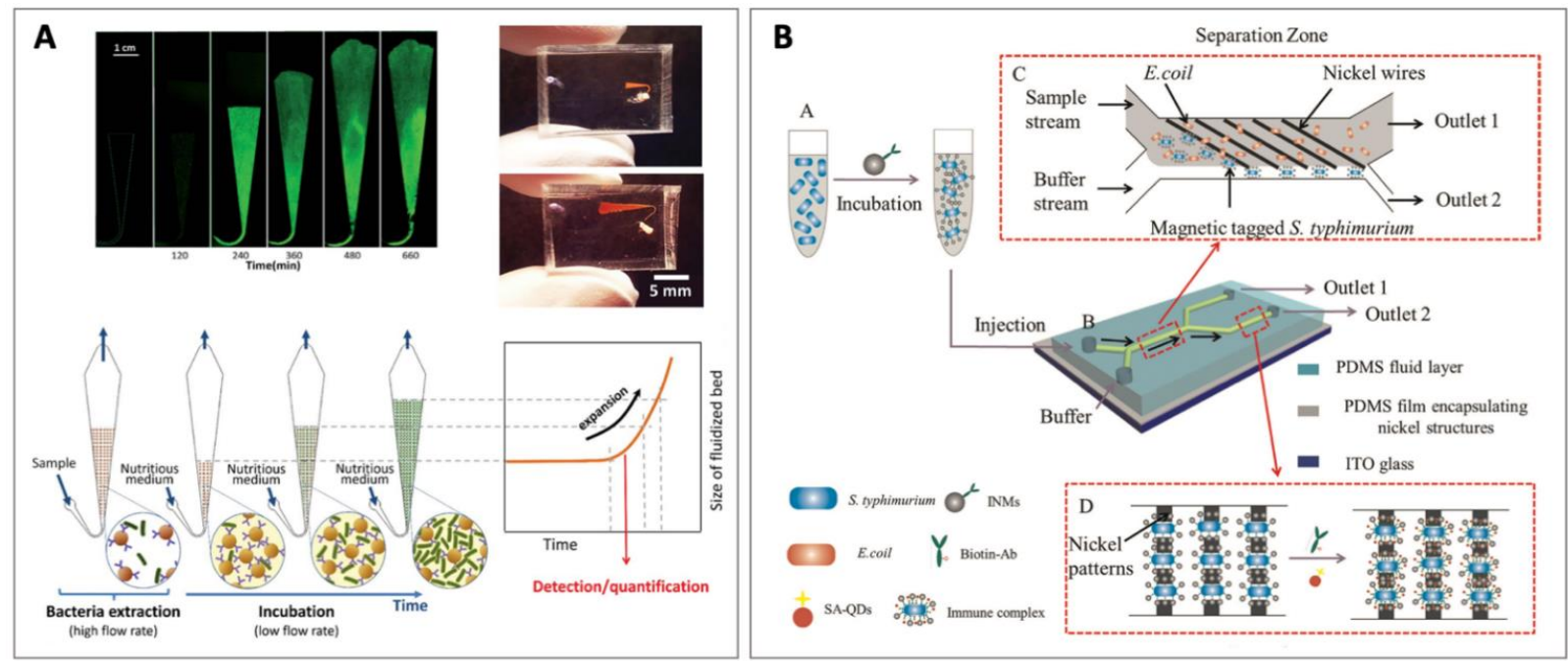

Figure 22. Microfluidic platforms for pathogenic bacteria detection. (A) Bacterial detection using a microfluidic fluidized bed. Quantitative detection can be performed by measuring the bed expansion. Reprinted with permission from [284]. (B) Microfluidic device integrating a magnetic separation stage and a detection stage based on magnetic target capture and sandwich assay. Reprinted with permission from [287]. Copyright (C) 2015 Elsevier B.V. All rights reserved. 


\subsection{Other Applications}

While we have focused our attention here on the widely explored fields of CTCs and pathogen detection, there are many other applications related to magnetic separation, such as detection of malaria-infected cells [288-292], peripheral blood lymphocytes sorting in different $\mathrm{T}$ cell subsets for immunotherapy [293,294], cell counting for disease monitoring [295], as well as phenotypic cell sorting. The Kelley group has developed several microfluidic devices for high-throughput analysis based on the MagRC concept (see Section 4.2.2). One of them was used to separate a cell sample into distinct cell subpopulations expressing varying levels of surface biomarkers and perform high-throughput phenotypic CRISPR screens. The method allowed processing of an entire genome-wide screen containing more than $10^{8}$ cells in less than $1 \mathrm{hr}$ [296]. The concept exploited here could similarly be applied to CTC profiling, antibiotic-resistant bacteria identification, and stem cell analysis [156]. This last field of investigation is also attracting a lot of interest $[297,298]$. Hematopoietic progenitor cell isolation is, for instance, a critical step in therapies based on hematopoietic stem cell transplantation for reconstitution of hematopoiesis in cancer patients [6]. Magnetic selection also enables enrichment of CD34+ blood stem cells from a donor graft prior to transplantation, while removing other cells that can cause graft-versus-host disease, as performed by the CliniMACS CD34 Reagent System (Miltenyi Biotec), an FDA approved medical device using antibodies conjugated to MNPs. In such applications, where certain cells will ultimately be implanted in vivo, negative selection strategies leaving target cells untouched could be preferred, or alternatively magnetic bead detachment should be made possible [299].

\section{Conclusions}

Although this review has attempted to cover many aspects of magnetic cell separation, it is far from being exhaustive, the possible applications and associated technological development being countless. A plethora of articles related to the subject have been written in the last decade, reflecting the excellent dynamics of the field. Magnetic cell separation has reached a certain maturity, as suggested by indicators such as certification and approval of medical devices, including for in vivo use. There are still some limitations to overcome for optimal development of MAP-based separation approaches, one of which being their cost, which remains high compared to other separation techniques. The development of label-free approaches based on magnetism, the large-scale production of MNPs, as well as the more systematic use of synthetic ligands, such as aptamers and peptides, should help to solve this issue. There is also a great need for the development of disposable, low-cost devices, and bedside diagnostic tools accessible in low-resource settings, which will be boosted by the emergence of new, easy-to-process materials, relying on affordable technologies, such as $3 \mathrm{D}$ printing. As regards improvements that can be expected on the theoretical side, a better comprehension of the collective behavior of magnetic objects should help understanding of how cooperative magnetophoresis and magnetophoreticinduced convective capture [300] could be exploited in new separator designs and how to optimize fluidized bed or ferrofluid-related experiments. Lastly, a crucial point for the efficient isolation of rare cells is to push further the limits that can be reached in terms of selectivity and sensitivity. In this respect, the combination of several approaches in hybrid microfluidic devices has great promise.

Funding: This research received no external funding.

Institutional Review Board Statement: Not applicable.

Informed Consent Statement: Not applicable.

Data Availability Statement: Not applicable.

Acknowledgments: The authors thank Laure Franqueville for her valuable comments on the manuscript. 
Conflicts of Interest: The authors declare no conflict of interest.

$\begin{array}{ll}\text { Abbreviations } \\ \text { CTC } & \text { circulating tumor cell } \\ \text { IMS } & \text { immunomagnetic cell separation } \\ \text { MAP } & \text { magnetophoresis } \\ \text { MNP } & \text { magnetic nano particle } \\ \text { RBC } & \text { red blood cell } \\ \text { WBC } & \text { white blood cell }\end{array}$

\section{References}

1. Amos, P.J.; Cagavi Bozkulak, E.; Qyang, Y. Methods of Cell Purification: A Critical Juncture for Laboratory Research and Translational Science. Cells Tissues Organs 2012, 195, 26-40. [CrossRef] [PubMed]

2. Tomlinson, M.J.; Tomlinson, S.; Yang, X.B.; Kirkham, J. Cell separation: Terminology and practical considerations. J. Tissue Eng. 2013, 4, 204173141247269. [CrossRef] [PubMed]

3. $\quad$ Faraghat, S.A.; Hoettges, K.F.; Steinbach, M.K.; Van Der Veen, D.R.; Brackenbury, W.J.; Henslee, E.A.; Labeed, F.H.; Hughes, M.P. High-Throughput, low-loss, low-cost, and label-free cell separation using electrophysiology-Activated cell enrichment. Proc. Natl. Acad. Sci. USA 2017, 114, 4591-4596. [CrossRef] [PubMed]

4. Renggli, S.; Keck, W.; Jenal, U.; Ritz, D. Role of autofluorescence in flow cytometric analysis of Escherichia coli treated with bactericidal antibiotics. J. Bacteriol. 2013, 195, 4067-4073. [CrossRef]

5. Hira, J.; Wolfson, D.; Andersen, A.J.C.; Haug, T.; Stensvåg, K. Autofluorescence mediated red spherulocyte sorting provides insights into the source of spinochromes in sea urchins. Sci. Rep. 2020, 10, 1149. [CrossRef]

6. Zborowski, M.; Chalmers, J.J.; Moore, L.R. Rare Cell Separation and Analysis by Magnetic Sorting. Anal. Chem. 2011, 83, 8050-8056. [CrossRef]

7. Sutermaster, B.A.; Darling, E.M. Considerations for high-yield, high-throughput cell enrichment: Fluorescence versus magnetic sorting. Sci. Rep. 2019, 9, 227. [CrossRef]

8. Maes, E.; Cools, N.; Willems, H.; Baggerman, G. FACS-based proteomics enables profiling of proteins in rare cell populations. Int. J. Mol. Sci. 2020, 21, 6557. [CrossRef]

9. Pan, J.; Wan, J. Methodological comparison of FACS and MACS isolation of enriched microglia and astrocytes from mouse brain. J. Immunol. Methods 2020, 486, 112834. [CrossRef]

10. Tripathi, H.; Peng, H.; Donahue, R.; Chelvarajan, L.; Gottipati, A.; Levitan, B.; Al-Darraji, A.; Gao, E.; Abdel-Latif, A.; Berron, B.J. Isolation Methods for Human CD34 Subsets Using Fluorescent and Magnetic Activated Cell Sorting: An In Vivo Comparative Study. Stem Cell Rev. Rep. 2020, 16, 413-423. [CrossRef]

11. Shields, C.W.; Ohiri, K.A.; Szott, L.M.; López, G.P. Translating microfluidics: Cell separation technologies and their barriers to commercialization. Cytom. Part B Clin. Cytom. 2017, 92, 115-125. [CrossRef] [PubMed]

12. Shields, C.W., IV.; Reyes, C.D.; López, G.P.; Shields, C.W., IV.; Reyes, C.D.; López, G.P.; Wyatt Shields, C., IV.; Reyes, C.D.; López, G.P. Microfluidic cell sorting: A review of the advances in the separation of cells from debulking to rare cell isolation. Lab Chip 2015, 15, 1230-1249. [CrossRef]

13. Liang, W.; Liu, J.; Yang, X.; Zhang, Q.; Yang, W.; Zhang, H.; Liu, L. Microfluidic-based cancer cell separation using active and passive mechanisms. Microfluid. Nanofluid. 2020, 24, 26. [CrossRef]

14. Bayareh, M. An updated review on particle separation in passive microfluidic devices. Chem. Eng. Process.-Process Intensif. 2020, 153, 107984. [CrossRef]

15. Catarino, S.O.; Rodrigues, R.O.; Pinho, D.; Miranda, J.M.; Minas, G.; Lima, R. Blood Cells Separation and Sorting Techniques of Passive Microfluidic Devices: From Fabrication to Applications. Micromachines 2019, 10, 593. [CrossRef]

16. Wu, M.; Ozcelik, A.; Rufo, J.; Wang, Z.; Fang, R.; Jun Huang, T. Acoustofluidic separation of cells and particles. Microsystems Nanoeng. 2019, 5, 32. [CrossRef] [PubMed]

17. Hughes, M.P. Fifty years of dielectrophoretic cell separation technology. Biomicrofluidics 2016, 10, 032801. [CrossRef]

18. Yan, S.; Zhang, J.; Yuan, D.; Li, W. Hybrid microfluidics combined with active and passive approaches for continuous cell separation. Electrophoresis 2017, 38, 238-249. [CrossRef]

19. Dalili, A.; Samiei, E.; Hoorfar, M. A review of sorting, separation and isolation of cells and microbeads for biomedical applications: Microfluidic approaches. Analyst 2019, 144, 87-113. [CrossRef]

20. Plouffe, B.D.; Murthy, S.K.; Lewis, L.H. Fundamentals and application of magnetic particles in cell isolation and enrichment: A review. Rep. Prog. Phys. 2015, 78, 016601. [CrossRef]

21. Montoya Mira, J.; Sapre, A.A.; Walker, B.S.; Alvarez, J.B.; Gustafson, K.T.; Tu, E.; Fischer, J.M.; Wong, M.H.; Esener, S.; Chiu, Y.-J. Label-free enrichment of rare unconventional circulating neoplastic cells using a microfluidic dielectrophoretic sorting device. Commun. Biol. 2021, 4, 1130. [CrossRef]

22. Smith, A.J.; O’Rorke, R.D.; Kale, A.; Rimsa, R.; Tomlinson, M.J.; Kirkham, J.; Davies, A.G.; Wälti, C.; Wood, C.D. Rapid cell separation with minimal manipulation for autologous cell therapies. Sci. Rep. 2017, 7, 41872. [CrossRef] 
23. Chen, Y.; Wu, M.; Ren, L.; Liu, J.; Whitley, P.H.; Wang, L.; Huang, T.J. High-throughput acoustic separation of platelets from whole blood. Lab Chip 2016, 16, 3466-3472. [CrossRef] [PubMed]

24. Urbansky, A.; Ohlsson, P.; Lenshof, A.; Garofalo, F.; Scheding, S.; Laurell, T. Rapid and effective enrichment of mononuclear cells from blood using acoustophoresis. Sci. Rep. 2017, 7, 17161. [CrossRef] [PubMed]

25. Munaz, A.; Shiddiky, M.J.A.; Nguyen, N.T. Recent advances and current challenges in magnetophoresis based micro magnetofluidics. Biomicrofluidics 2018, 12, 031501. [CrossRef]

26. Rodríguez-Villarreal, A.I.; Tarn, M.D.; Madden, L.A.; Lutz, J.B.; Greenman, J.; Samitier, J.; Pamme, N. Flow focussing of particles and cells based on their intrinsic properties using a simple diamagnetic repulsion setup. Lab Chip 2011, 11, 1240-1248. [CrossRef]

27. Pamme, N. Continuous flow separations in microfluidic devices. Lab Chip 2007, 7, 1644-1659. [CrossRef] [PubMed]

28. Gooding, D. Final Steps to the Field Theory: Faraday's Study of Magnetic Phenomena, 1845-1850. Hist. Stud. Phys. Sci. 1981, 11, 231-275. [CrossRef]

29. Schenck, J.F. Safety of Strong, Static Magnetic Fields. J. Magn. Reson. Imaging 2000, 19, 2-19. [CrossRef]

30. Vargas, G.; Cypriano, J.; Correa, T.; Leão, P.; Bazylinski, D.A.; Abreu, F. Applications of Magnetotactic Bacteria, Magnetosomes and Magnetosome Crystals in Biotechnology and Nanotechnology: Mini-Review. Molecules 2018, 23, 2438. [CrossRef]

31. Alphandéry, E. Applications of magnetosomes synthesized by magnetotactic bacteria in medicine. Front. Bioeng. Biotechnol. 2014, 2, 5. [CrossRef] [PubMed]

32. Myklatun, A.; Cappetta, M.; Winklhofer, M.; Ntziachristos, V.; Westmeyer, G.G. Microfluidic sorting of intrinsically magnetic cells under visual control. Sci. Rep. 2017, 7, 6942. [CrossRef] [PubMed]

33. Wahajuddin, S.A. Superparamagnetic iron oxide nanoparticles: Magnetic nanoplatforms as drug carriers. Int. J. Nanomed. 2012, 7, 3445-3471. [CrossRef]

34. Oh, J.K.; Park, J.M. Iron oxide-based superparamagnetic polymeric nanomaterials: Design, preparation, and biomedical application. Prog. Polym. Sci. 2011, 36, 168-189. [CrossRef]

35. Kudr, J.; Haddad, Y.; Richtera, L.; Heger, Z.; Cernak, M.; Adam, V.; Zitka, O. Magnetic Nanoparticles: From Design and Synthesis to Real World Applications. Nanomaterials 2017, 7, 243. [CrossRef] [PubMed]

36. Xiao, D.; Lu, T.; Zeng, R.; Bi, Y. Preparation and highlighted applications of magnetic microparticles and nanoparticles: A review on recent advances. Microchim. Acta 2016, 183, 2655-2675. [CrossRef]

37. Mosayebi, J.; Kiyasatfar, M.; Laurent, S. Synthesis, Functionalization, and Design of Magnetic Nanoparticles for Theranostic Applications. Adv. Healthc. Mater. 2017, 6, 1700306. [CrossRef]

38. Gijs, M.A.M.; Lacharme, F.; Lehmann, U. Microfluidic applications of magnetic particles for biological analysis and catalysis. Chem. Rev. 2010, 110, 1518-1563. [CrossRef]

39. Ruffert, C. Magnetic Bead-Magic Bullet. Micromachines 2016, 7, 21. [CrossRef]

40. Winkleman, A.; Gudiksen, K.L.; Ryan, D.; Whitesides, G.M.; Greenfield, D.; Prentiss, M. A magnetic trap for living cells suspended in a paramagnetic buffer. Appl. Phys. Lett. 2004, 85, 2411-2413. [CrossRef]

41. Kauffmann, P.; Ith, A.; O’Brien, D.; Gaude, V.; Boué, F.; Combe, S.; Bruckert, F.; Schaack, B.; Dempsey, N.M.; Haguet, V.; et al. Diamagnetically trapped arrays of living cells above micromagnets. Lab Chip 2011, 11, 3153-3161. [CrossRef]

42. Frenea-Robin, M.; Chetouani, H.; Haddour, N.; Rostaing, H.; Laforet, J.; Reyne, G. Contactless diamagnetic trapping of living cells onto a micromagnet array. In Proceedings of the 2008 30th Annual International Conference of the IEEE Engineering in Medicine and Biology Society, Vancouver, BC, Canada, 20-24 August 2008; pp. 3360-3363.

43. Zanini, L.F.; Osman, O.; Frenea-Robin, M.; Haddour, N.; Dempsey, N.M.; Reyne, G.; Dumas-Bouchiat, F. Micromagnet structures for magnetic positioning and alignment. J. Appl. Phys. 2012, 111, 07B312. [CrossRef]

44. Osman, O.; Toru, S.; Dumas-Bouchiat, F.; Dempsey, N.M.; Haddour, N.; Zanini, L.-F.; Buret, F.; Reyne, G.; Frenea-Robin, M. Microfluidic immunomagnetic cell separation using integrated permanent micromagnets. Biomicrofluidics 2013, 7, 054115. [CrossRef]

45. Cugat, O.; Delamare, J.; Reyne, G. Magnetic micro-actuators and systems (MAGMAS). IEEE Trans. Magn. 2003, 39, 3607-3612. [CrossRef]

46. Chalmers, J.J.; Haam, S.; Zhao, Y.; McCloskey, K.; Moore, L.; Zborowski, M.; Williams, P.S. Quantification of cellular properties from external fields and resulting induced velocity: Magnetic susceptibility. Biotechnol. Bioeng. 1999, 64, 519-526. [CrossRef]

47. Chalmers, J.J.; Xiong, Y.; Jin, X.; Shao, M.; Tong, X.; Farag, S.; Zborowski, M. Quantification of non-specific binding of magnetic micro- and nanoparticles using cell tracking velocimetry: Implication for magnetic cell separation and detection. Biotechnol. Bioeng. 2010, 105, 1078-1093. [CrossRef]

48. Chalmers, J.J.; Jin, X.; Palmer, A.F.; Yazer, M.H.; Moore, L.; Amaya, P.; Park, K.; Pan, X.; Zborowski, M. Femtogram Resolution of Iron Content on a Per Cell Basis: Ex Vivo Storage of Human Red Blood Cells Leads to Loss of Hemoglobin. Anal. Chem. 2017, 89, 3702-3709. [CrossRef]

49. Leong, S.S.; Yeap, S.P.; Lim, J.K. Working principle and application of magnetic separation for biomedical diagnostic at high- and low-field gradients. Interface Focus 2016, 6, 20160048. [CrossRef] [PubMed]

50. Bacon, K.; Lavoie, A.; Rao, B.M.; Daniele, M.; Menegatti, S. Past, Present, and Future of Affinity-based Cell Separation Technologies. Acta Biomater. 2020, 112, 29-51. [CrossRef]

51. Gray, B.P.; Requena, M.D.; Nichols, M.D.; Sullenger, B.A. Aptamers as Reversible Sorting Ligands for Preparation of Cells in Their Native State. Cell Chem. Biol. 2020, 27, 232-244.e7. [CrossRef] 
52. Saei, A.; Asfia, S.; Kouchakzadeh, H.; Rahmandoust, M. Antibody-modified magnetic nanoparticles as specific high-efficient cell-separation agents. J. Biomed. Mater. Res. B Appl. Biomater. 2020, 108, 2633-2642. [CrossRef]

53. Po, J.W.; Roohullah, A.; Lynch, D.; DeFazio, A.; Harrison, M.; Harnett, P.R.; Kennedy, C.; de Souza, P.; Becker, T.M. Improved ovarian cancer EMT-CTC isolation by immunomagnetic targeting of epithelial EpCAM and mesenchymal N-cadherin. J. Circ. Biomark. 2018, 7, 184945441878261. [CrossRef]

54. Luciani, M.; Di Febo, T.; Zilli, K.; Di Giannatale, E.; Armillotta, G.; Manna, L.; Minelli, F.; Tittarelli, M.; Caprioli, A. Rapid Detection and Isolation of Escherichia coli O104:H4 from Milk Using Monoclonal Antibody-coated Magnetic Beads. Front. Microbiol. 2016, 7, 942. [CrossRef]

55. Catuogno, S.; Esposito, C.L. Aptamer Cell-Based Selection: Overview and Advances. Biomedicines 2017, 5, 49. [CrossRef]

56. Hassan, E.M.; Willmore, W.G.; DeRosa, M.C. Aptamers: Promising Tools for the Detection of Circulating Tumor Cells. Nucleic Acid Ther. 2016, 26, 335-347. [CrossRef] [PubMed]

57. Chen, Y.; Tyagi, D.; Lyu, M.; Carrier, A.J.; Nganou, C.; Youden, B.; Wang, W.; Cui, S.; Servos, M.; Oakes, K.; et al. Regenerative NanoOctopus Based on Multivalent-Aptamer- Functionalized Magnetic Microparticles for E ff ective Cell Capture in Whole Blood. Anal. Chem. 2019, 91, 4017-4022. [CrossRef] [PubMed]

58. Modh, H.; Scheper, T.; Walter, J.G. Aptamer-modified magnetic beads in biosensing. Sensors 2018, 18, 1041. [CrossRef] [PubMed]

59. Labib, M.; Green, B.; Mohamadi, R.M.; Mepham, A.; Ahmed, S.U.; Mahmoudian, L.; Chang, I.H.; Sargent, E.H.; Kelley, S.O. Aptamer and Antisense-Mediated Two-Dimensional Isolation of Specific Cancer Cell Subpopulations. J. Am. Chem. Soc. 2016, 138, 2476-2479. [CrossRef]

60. Herr, J.K.; Smith, J.E.; Medley, C.D.; Shangguan, D.; Tan, W. Aptamer-conjugated nanoparticles for selective collection and detection of cancer cells. Anal. Chem. 2006, 78, 2918-2924. [CrossRef]

61. Haghighi, F.H.; Binaymotlagh, R.; Mirahmadi-Zare, S.Z.; Hadadzadeh, H. Aptamer/magnetic nanoparticles decorated with fluorescent gold nanoclusters for selective detection and collection of human promyelocytic leukemia (HL-60) cells from a mixture. Nanotechnology 2020, 31, 25605. [CrossRef]

62. Lee, M.Y.; Lufkin, T. Development of the "three-step macs": A novel strategy for isolating rare cell populations in the absence of known cell surface markers from complex animal tissue. J. Biomol. Tech. 2012, 23, 69-77. [CrossRef]

63. Matheson, N.J.; Peden, A.A.; Lehner, P.J. Antibody-free magnetic cell sorting of genetically modified primary human CD4+ T cells by one-step streptavidin affinity purification. PLOS ONE 2014, 9, e0111437. [CrossRef]

64. Stoffels, M.; Ludwig, W.; Schleifer, K.H. rRNA probe-based cell fishing of bacteria. Environ. Microbiol. 1999, 1, 259-271. [CrossRef]

65. Pivetal, J.; Royet, D.; Ciuta, G.; Frenea-Robin, M.; Haddour, N.; Dempsey, N.M.; Dumas-Bouchiat, F.; Simonet, P. Micro-magnet arrays for specific single bacterial cell positioning. J. Magn. Magn. Mater. 2015, 380, 72-77. [CrossRef]

66. Royet, D.; Dempsey, N.M.; Simonet, P.; Frénéa-Robin, M. A new magnetic cell fishing approach based on hybridization chain reaction: HCR-MISH. Sens. Actuators B Chem. 2018, 273, 126-132. [CrossRef]

67. Bastian, F.; Melayah, D.; Hugoni, M.; Dempsey, N.M.; Simonet, P.; Frenea-Robin, M.; Fraissinet-Tachet, L. Eukaryotic Cell Capture by Amplified Magnetic in situ Hybridization Using Yeast as a Model. Front. Microbiol. 2021, 12, 3344. [CrossRef]

68. Robert, D.; Pamme, N.; Conjeaud, H.; Gazeau, F.; Iles, A.; Wilhelm, C. Cell sorting by endocytotic capacity in a microfluidic magnetophoresis device. Lab Chip 2011, 11, 1902-1910. [CrossRef] [PubMed]

69. Moore, L.R.; Mizutani, D.; Tanaka, T.; Buck, A.; Yazer, M.; Zborowski, M.; Chalmers, J.J. Continuous, intrinsic magnetic depletion of erythrocytes from whole blood with a quadrupole magnet and annular flow channel; pilot scale study. Biotechnol. Bioeng. 2018, 115, 1521-1530. [CrossRef]

70. Furlani, E.P. Magnetophoretic separation of blood cells at the microscale. J. Phys. D Appl. Phys. 2007, 40, 1313. [CrossRef]

71. Shiriny, A.; Bayareh, M. On magnetophoretic separation of blood cells using Halbach array of magnets. Meccanica 2020, 55, 1903-1916. [CrossRef]

72. Abdel Fattah, A.R.; Ghosh, S.; Puri, I.K. High gradient magnetic field microstructures for magnetophoretic cell separation. J. Chromatogr. B 2016, 1027, 194-199. [CrossRef]

73. Han, K.H.; Frazier, A.B. Paramagnetic capture mode magnetophoretic microseparator for high efficiency blood cell separations. Lab Chip 2006, 6, 265-273. [CrossRef]

74. Shen, F.; Hwang, H.; Hahn, Y.K.; Park, J.-K. Label-Free Cell Separation Using a Tunable Magnetophoretic Repulsion Force. Anal Chem. 2012, 84, 3075-3081. [CrossRef]

75. Baday, M.; Calamak, S.; Durmus, N.G.; Davis, R.W.; Steinmetz, L.M.; Demirci, U. Integrating Cell Phone Imaging with Magnetic Levitation (i-LEV) for Label-Free Blood Analysis at the Point-of-Living. Small 2016, 12, 1222-1229. [CrossRef]

76. Zhang, X.; Sun, L.; Yu, Y.; Zhao, Y. Flexible Ferrofluids: Design and Applications. Adv. Mater. 2019, 31, 1903497. [CrossRef]

77. Zhao, W.; Cheng, R.; Lim, S.H.; Miller, J.R.; Zhang, W.; Tang, W.; Xie, J.; Mao, L. Biocompatible and label-free separation of cancer cells from cell culture lines from white blood cells in ferrofluids. Lab Chip 2017, 17, 2243-2255. [CrossRef] [PubMed]

78. Gao, Q.H.; Zhang, W.M.; Zou, H.X.; Li, W.B.; Yan, H.; Peng, Z.K.; Meng, G. Label-free manipulation: Via the magneto-Archimedes effect: Fundamentals, methodology and applications. Mater. Horizons 2019, 6, 1359-1379. [CrossRef]

79. Zhao, W.; Zhu, T.; Cheng, R.; Liu, Y.; He, J.; Qiu, H.; Wang, L.; Nagy, T.; Querec, T.D.; Unger, E.R.; et al. Label-Free and Continuous-Flow Ferrohydrodynamic Separation of HeLa Cells and Blood Cells in Biocompatible Ferrofluids. Adv. Funct. Mater. 2016, 26, 3990-3998. [CrossRef] [PubMed] 
80. Liu, Y.; Zhao, W.; Cheng, R.; Harris, B.N.; Murrow, J.R.; Hodgson, J.; Egan, M.; Bankey, A.; Nikolinakos, P.G.; Laver, T.; et al. Fundamentals of integrated ferrohydrodynamic cell separation in circulating tumor cell isolation. Lab Chip 2021, 21, 1706-1723. [CrossRef] [PubMed]

81. Shamloo, A.; Besanjideh, M. Investigation of a Novel Microfluidic Device for Label-Free Ferrohydrodynamic Cell Separation on a Rotating Disk. IEEE Trans. Biomed. Eng. 2020, 67, 372-378. [CrossRef]

82. Mccloskey, K.E.; Chalmers, J.J.; Zborowski, M. Magnetic Cell Separation: Characterization of Magnetophoretic Mobility. Anal Chem. 2003, 75, 6868-6874. [CrossRef]

83. Li, F.; Xu, H.; Zhao, Y. Magnetic particles as promising circulating tumor cell catchers assisting liquid biopsy in cancer diagnosis: A review. Trends Anal. Chem. 2021, 145, 116453. [CrossRef]

84. Gordon, R.; Hogan, C.E.; Neal, M.L.; Anantharam, V.; Kanthasamy, A.G.; Kanthasamy, A. A simple magnetic separation method for high-yield isolation of pure primary microglia. J. Neurosci. Methods 2011, 194, 287-296. [CrossRef] [PubMed]

85. Pezzi, H.M.; Niles, D.J.; Schehr, J.L.; Beebe, D.J.; Lang, J.M. Integration of Magnetic Bead-Based Cell Selection into Complex Isolations. ACS Omega 2018, 3, 3908-3917. [CrossRef] [PubMed]

86. Yu, Y.; Yang, Y.; Wang, F.; Ding, J.; Meng, S.; Li, C.; Tang, D.; Yin, X. Functional and biocompatible polymeric ionic liquid (PIL)-Decorated immunomagnetic nanospheres for the efficient capture of rare number CTCs. Anal. Chim. Acta 2018, 1044, 162-173. [CrossRef] [PubMed]

87. Li, F.; Li, F.; Luo, D.; Lai, W.; Xiong, Y.; Xu, H. Biotin-exposure-based immunomagnetic separation coupled with nucleic acid lateral flow biosensor for visibly detecting viable Listeria monocytogenes. Anal. Chim. Acta 2018, 1017, 48-56. [CrossRef]

88. Jo, S.-M.; Lee, J.; Heu, W.; Kim, H.-S. Nanotentacle-Structured Magnetic Particles for Efficient Capture of Circulating Tumor Cells. Small 2015, 11, 1975-1982. [CrossRef]

89. Wang, Z.; Qin, W.; Zhuang, J.; Wu, M.; Li, Q.; Fan, C.; Zhang, Y. Virus-Mimicking Cell Capture Using Heterovalency Magnetic DNA Nanoclaws. ACS Appl. Mater. Interfaces 2019, 11, 12244-12252. [CrossRef]

90. Zhang, P.; Zhang, Y.; Gao, M.; Zhang, X. Dendrimer-assisted hydrophilic magnetic nanoparticles as sensitive substrates for rapid recognition and enhanced isolation of target tumor cells. Talanta 2016, 161, 925-931. [CrossRef] [PubMed]

91. Chen, C.; Chen, K.; Pan, Y.; Lee, T.; Hsiung, L.; Lin, C.; Chen, C.; Lin, C.; Chiang, B.; Wo, A.M. Separation and detection of rare cells in a microfluidic disk via negative selection. Lab Chip 2011, 3, 474-483. [CrossRef]

92. Chu, Q.; Mu, W.; Lan, C.; Liu, Y.; Gao, T.; Guan, L.; Fang, Y.; Zhang, Z.; Liu, Y.; Liu, Y.; et al. High-specific isolation and instant observation of circulating tumour cell from hcc patients via glypican-3 immunomagnetic fluorescent nanodevice. Int. J. Nanomed. 2021, 16, 4161-4173. [CrossRef] [PubMed]

93. Chen, L.; Wu, L.-L.; Zhang, Z.-L.; Hu, J.; Tang, M.; Qi, C.-B.; Li, N.; Pang, D.-W. Biofunctionalized magnetic nanospheres-based cell sorting strategy for efficient isolation, detection and subtype analyses of heterogeneous circulating hepatocellular carcinoma cells. Biosens. Bioelectron. 2016, 85, 633-640. [CrossRef]

94. Sun, C.; Hsieh, Y.P.; Ma, S.; Geng, S.; Cao, Z.; Li, L.; Lu, C. Immunomagnetic separation of tumor initiating cells by screening two surface markers. Sci. Rep. 2017, 7, 40632. [CrossRef]

95. Lin, D.; Maecker, H.T. Mass Cytometry Assays for Antigen-Specific T Cells Using CyTOF. Methods Mol. Biol. 2018, 1678, 37-47. [CrossRef] [PubMed]

96. Lu, N.N.; Xie, M.; Wang, J.; Lv, S.W.; Yi, J.S.; Dong, W.G.; Huang, W.H. Biotin-triggered decomposable immunomagnetic beads for capture and release of circulating tumor cells. ACS Appl. Mater. Interfaces 2015, 7, 8817-8826. [CrossRef] [PubMed]

97. Pankratz, J.; Schmachtenberg, S.; Jansen, N.; Hansen, M.; Krauthäuser, S.; Kinkhabwala, A.; Schlegel, K.; Meiler, S.; Siewert, C.; Bartholomäus, A.; et al. Abstract 4048: REAlease ${ }^{\circledR}$ technology: Controlled release of antibody-fluorochrome conjugates for maximal flexibility in flow sorting and fluorescence microscopy applications. In Proceedings of the Clinical Research (Excluding Clinical Trials), Atlanta, GA, USA, 29 March-3 April 2019; American Association for Cancer Research: Philadelphia, PA, USA; Atlanta, GA, USA, 2019; p. 4048.

98. Evaristo, C.; Steinbrück, P.; Pankratz, J.; Yu, Z.; Dose, C. REAlease ${ }^{\mathrm{TM}}$ Immunomagnetic Separation Technology with reversible labeling for positive selection of leukocytes. J. Immunol. 2018, 200, 174-178.

99. Weil, B.D.; Jenkins, M.J.; Uddin, S.; Bracewell, D.G.; Wellings, D.; Farid, S.S.; Veraitch, F. An integrated experimental and economic evaluation of cell therapy affinity purification technologies. Regen. Med. 2017, 12, 397-417. [CrossRef] [PubMed]

100. Peng, J.; Zhao, Q.; Zheng, W.; Li, W.; Li, P.; Zhu, L.; Liu, X.; Shao, B.; Li, H.; Wang, C.; et al. Peptide-Functionalized Nanomaterials for the E ffi cient Isolation of HER2-Positive Circulating Tumor Cells. ACS Appl. Mater. Interfaces 2017, 9, 18423-18428. [CrossRef]

101. Tombelli, S.; Minunni, M.; Mascini, M. Aptamers-based assays for diagnostics, environmental and food analysis. Biomol. Eng. 2007, 24, 191-200. [CrossRef]

102. Kaur, H. Recent developments in cell-SELEX technology for aptamer selection. Biochim. Biophys. Acta-Gen. Subj. 2018, 1862, 2323-2329. [CrossRef]

103. Famulok, M.; Mayer, G. Aptamers and SELEX in Chemistry \& Biology. Chem. Biol. 2014, 21, 1055-1058. [CrossRef]

104. Sun, C.; Zhang, R.; Gao, M.; Zhang, X. A rapid and simple method for efficient capture and accurate discrimination of circulating tumor cells using aptamer conjugated magnetic beads and surface-enhanced Raman scattering imaging. Anal. Bioanal. Chem. 2015, 407, 8883-8892. [CrossRef] [PubMed]

105. Wu, L.; Wang, Y.; Xu, X.; Liu, Y.; Lin, B.; Zhang, M.; Zhang, J.; Wan, S.; Yang, C.; Tan, W. Aptamer-Based Detection of Circulating Targets for Precision Medicine. Chem. Rev. 2021, 121, 12035-12105. [CrossRef] [PubMed] 
106. Zhao, Y.; Xu, D.; Tan, W. Aptamer-functionalized nano/micro-materials for clinical diagnosis: Isolation, release and bioanalysis of circulating tumor cells. Integr. Biol. 2017, 9, 188-205. [CrossRef] [PubMed]

107. Zamay, G.S.; Kolovskaya, O.S.; Zamay, T.N.; Glazyrin, Y.E.; Krat, A.V.; Zubkova, O.; Spivak, E.; Wehbe, M.; Gargaun, A.; Muharemagic, D.; et al. Aptamers Selected to Postoperative Lung Adenocarcinoma Detect Circulating Tumor Cells in Human Blood. Mol. Ther. 2015, 23, 1486-1496. [CrossRef]

108. Fang, S.; Wang, C.; Xiang, J.; Cheng, L.; Song, X.; Xu, L.; Peng, R.; Liu, Z. Aptamer-conjugated upconversion nanoprobes assisted by magnetic separation for effective isolation and sensitive detection of circulating tumor cells. Nano Res. 2014, 7, 1327-1336. [CrossRef]

109. Li, Z.; Wang, G.; Shen, Y.; Guo, N.; Ma, N. DNA-Templated Magnetic Nanoparticle-Quantum Dot Polymers for Ultrasensitive Capture and Detection of Circulating Tumor Cells. Adv. Funct. Mater. 2018, 28, 1707152. [CrossRef]

110. Xu, H.; Dong, B.; Xu, S.S.; Xu, S.S.; Sun, X.; Sun, J.; Yang, Y.; Xu, L.; Bai, X.; Zhang, S.; et al. High purity microfluidic sorting and in situ inactivation of circulating tumor cells based on multifunctional magnetic composites. Biomaterials 2017, 138, 69-79. [CrossRef]

111. Dong, Z.; Tang, C.; Zhao, L.; Xu, J.; Wu, Y.; Tang, X.; Zhou, W.; He, R.; Zhao, R.; Xu, L.; et al. A Microwell-Assisted Multiaptamer Immunomagnetic Platform for Capture and Genetic Analysis of Circulating Tumor Cells. Adv. Healthc. Mater. $2018,7,1801231$. [CrossRef] [PubMed]

112. Chen, Y.; Wang, W.; Tyagi, D.; Carrier, A.J.; Cui, S.; He, S.; Zhang, X. Non-invasive isolation of rare circulating tumor cells with a DNA mimic of double-sided tape using multimeric aptamers. Nanoscale 2019, 11, 5879-5883. [CrossRef]

113. Gao, T.; Ding, P. Isolation of DNA aptamers targeting N-cadherin and high-e ffi ciency capture of circulating tumor cells by using dual aptamers. Nanoscale 2020, 12, 22574-22585. [CrossRef]

114. Ma, H.; Liu, J.; Ali, M.M.; Mahmood, M.A.I.; Labanieh, L.; Lu, M.; Iqbal, S.M.; Zhang, Q.; Zhao, W.; Wan, Y. Nucleic acid aptamers in cancer research, diagnosis and therapy. Chem. Soc. Rev. 2015, 44, 1240-1256. [CrossRef]

115. Zhu, J.; Nguyen, T.; Pei, R.; Stojanovic, M.; Lin, Q. Specific capture and temperature-mediated release of cells in an aptamer-based microfluidic device. Lab Chip 2012, 12, 3504-3513. [CrossRef] [PubMed]

116. Oney, S.; Lam, R.T.S.; Bompiani, K.M.; Blake, C.M.; Quick, G.; Heidel, J.D.; Liu, J.Y.-C.; Mack, B.C.; Davis, M.E.; Leong, K.W.; et al. Development of universal antidotes to control aptamer activity. Nat. Med. 2009, 15, 1224-1228. [CrossRef] [PubMed]

117. Kacherovsky, N.; Cardle, I.I.; Cheng, E.L.; Yu, J.L.; Baldwin, M.L.; Salipante, S.J.; Jensen, M.C.; Pun, S.H. Traceless aptamermediated isolation of CD8+ T cells for chimeric antigen receptor T-cell therapy. Nat. Biomed. Eng. 2019, 3, 783-795. [CrossRef]

118. Wan, Q.; Liu, X.; Zu, Y. Oligonucleotide aptamers for pathogen detection and infectious disease control. Theranostics 2021, 11, 9133-9161. [CrossRef] [PubMed]

119. Wu, C.-H.; Liu, I.-J.; Lu, R.-M.; Wu, H.-C. Advancement and applications of peptide phage display technology in biomedical science. J. Biomed. Sci. 2016, 23, 8. [CrossRef] [PubMed]

120. Bozovičar, K.; Bratkovič, T. Evolving a Peptide: Library Platforms and Diversification Strategies. Int. J. Mol. Sci. 2020, 21, 215. [CrossRef]

121. Bai, L.; Du, Y.; Peng, J.; Liu, Y.; Wang, Y.; Yang, Y.; Wang, C. Peptide-based isolation of circulating tumor cells by magnetic nanoparticles. J. Mater. Chem. B 2014, 2, 4080-4088. [CrossRef]

122. Ding, J.; Wang, K.; Tang, W.-J.; Li, D.; Wei, Y.-Z.; Lu, Y.; Li, Z.-H.; Liang, X.-F. Construction of Epidermal Growth Factor Receptor Peptide Magnetic Nanovesicles with Lipid Bilayers for Enhanced Capture of Liver Cancer Circulating Tumor Cells. Anal. Chem. 2016, 88, 8997-9003. [CrossRef]

123. Salomon, D.S.; Brandt, R.; Ciardiello, F.; Normanno, N. Epidermal growth factor-related peptides and their receptors in human malignancies. Crit. Rev. Oncol. Hematol. 1995, 19, 183-232. [CrossRef]

124. Day, K.; Schneible, J.D.; Young, A.T.; Pozdin, V.A.; Van Den Driessche, G.; Gaffney, L.A.; Prodromou, R.; Freytes, D.O.; Fourches, D.; Daniele, M.; et al. Photoinduced reconfiguration to control the protein-binding affinity of azobenzene-cyclized peptides. $J$. Mater. Chem. B 2020, 8, 7413-7427. [CrossRef] [PubMed]

125. Fernández, M.; Javaid, F.; Chudasama, V. Advances in targeting the folate receptor in the treatment/imaging of cancers. Chem. Sci. 2017, 9, 790-810. [CrossRef]

126. Kaittanis, C.; Santra, S.; Perez, J.M. Role of Nanoparticle Valency in the Nondestructive Magnetic-Relaxation-Mediated Detection and Magnetic Isolation of Cells in Complex Media. J. Am. Chem. Soc. 2009, 131, 12780-12791. [CrossRef] [PubMed]

127. Liu, W.; Nie, L.; Li, F.; Aguilar, Z.P.; Xu, H.; Xiong, Y.; Fu, F.; Xu, H. Folic acid conjugated magnetic iron oxide nanoparticles for nondestructive separation and detection of ovarian cancer cells from whole blood. Biomater. Sci. 2016, 4, 159-166. [CrossRef] [PubMed]

128. Li, F.; Yang, G.; Aguilar, Z.P.; Xiong, Y.; Xu, H. Affordable and simple method for separating and detecting ovarian cancer circulating tumor cells using BSA coated magnetic nanoprobes modified with folic acid. Sens. Actuators B Chem. 2018, 262, 611-618. [CrossRef]

129. Nie, L.; Li, F.; Huang, X.; Aguilar, Z.P.; Wang, Y.A.; Xiong, Y.; Fu, F.; Xu, H. Folic Acid Targeting for Efficient Isolation and Detection of Ovarian Cancer CTCs from Human Whole Blood Based on Two-Step Binding Strategy. ACS Appl. Mater. Interfaces 2018, 10, 14055-14062. [CrossRef]

130. Meng, X.; Sun, P.; Xu, H.; Wang, Z. Folic acid-functionalized magnetic nanoprobes via a PAMAM dendrimer/SA-biotin mediated cascade-amplifying system for the efficient enrichment of circulating tumor cells. Biomater. Sci. 2020, 8, 6395-6403. [CrossRef] 
131. Mejia-Pous, C.; Viñuelas, J.; Faure, C.; Koszela, J.; Kawakami, K.; Takahashi, Y.; Gandrillon, O. A combination of transposable elements and magnetic cell sorting provides a very efficient transgenesis system for chicken primary erythroid progenitors. $B M C$ Biotechnol. 2009, 9, 81. [CrossRef]

132. David, R.; Groebner, M.; Franz, W.-M. Magnetic Cell Sorting Purification of Differentiated Embryonic Stem Cells Stably Expressing Truncated Human CD4 as Surface Marker. Stem Cells 2005, 23, 477-482. [CrossRef]

133. Shen, M.-J.; Olsthoorn, R.C.L.; Zeng, Y.; Bakkum, T.; Kros, A.; Boyle, A.L. Magnetic-Activated Cell Sorting Using Coiled-Coil Peptides: An Alternative Strategy for Isolating Cells with High Efficiency and Specificity. ACS Appl. Mater. Interfaces 2021, 13, 11621-11630. [CrossRef] [PubMed]

134. Zwirglmaier, K.; Ludwig, W.; Schleifer, K.-H. Improved method for polynucleotide probe-based cell sorting, using DNA-coated microplates. Appl. Environ. Microbiol. 2004, 70, 494-497. [CrossRef]

135. Zwirglmaier, K.; Ludwig, W.; Schleifer, K.H. Recognition of individual genes in a single bacterial cell by fluorescence in situ hybridization-RING-FISH. Mol. Microbiol. 2004, 51, 89-96. [CrossRef] [PubMed]

136. Pivetal, J.; Toru, S.; Frenea-Robin, M.; Haddour, N.; Cecillon, S.; Dempsey, N.M.; Dumas-Bouchiat, F.; Simonet, P. Selective isolation of bacterial cells within a microfluidic device using magnetic probe-based cell fishing. Sens. Actuators B Chem. 2014, 195, 581-589. [CrossRef]

137. Yamaguchi, T.; Kawakami, S.; Hatamoto, M.; Imachi, H.; Takahashi, M.; Araki, N.; Yamaguchi, T.; Kubota, K. In situ DNAhybridization chain reaction (HCR): A facilitated in situ HCR system for the detection of environmental microorganisms. Environ. Microbiol. 2015, 17, 2532-2541. [CrossRef]

138. Conner, S.D.; Schmid, S.L. Regulated portals of entry into the cell. Nature 2003, 422, 37-44. [CrossRef] [PubMed]

139. Rennick, J.J.; Johnston, A.P.R.; Parton, R.G. Key principles and methods for studying the endocytosis of biological and nanoparticle therapeutics. Nat. Nanotechnol. 2021, 16, 266-276. [CrossRef]

140. Osman, O.; Zanini, L.F.; Frénéa-Robin, M.; Dumas-Bouchiat, F.; Dempsey, N.M.; Reyne, G.; Buret, F.; Haddour, N. Monitoring the endocytosis of magnetic nanoparticles by cells using permanent micro-flux sources. Biomed. Microdevices 2012, 14, 947-954. [CrossRef]

141. Xuan, X. Recent Advances in Continuous-Flow Particle Manipulations Using Magnetic Fluids. Micromachines 2019, 10, 744. [CrossRef]

142. Zhao, W.; Cheng, R.; Miller, J.R.; Mao, L. Label-Free Microfluidic Manipulation of Particles and Cells in Magnetic Liquids. Adv. Funct. Mater. 2016, 26, 3916-3932. [CrossRef]

143. Mirica, K.A.; Shevkoplyas, S.S.; Phillips, S.T.; Gupta, M.; Whitesides, G.M. Measuring densities of solids and liquids using magnetic levitation: Fundamentals. J. Am. Chem. Soc. 2009, 131, 10049-10058. [CrossRef]

144. Watarai, H.; Namba, M. Capillary magnetophoresis of human blood cells and their magnetophoretic trapping in a flow system. $J$. Chromatogr. A 2002, 961, 3-8. [CrossRef]

145. Sarigil, O.; Anil-Inevi, M.; Yilmaz, E.; Mese, G.; Tekin, H.C.; Ozcivici, E. Label-free density-based detection of adipocytes of bone marrow origin using magnetic levitation. Analyst 2019, 144, 2942-2953. [CrossRef]

146. Rosensweig, R.E. Magnetic Fluids. Annu. Rev. Fluid Mech. 1987, 19, 437-461. [CrossRef]

147. Pratt, A. Environmental applications of magnetic nanoparticles. In Frontiers of Nanoscience; Elsevier Ltd.: Amsterdam, The Netherlands, 2014; Volume 6, pp. 259-307.

148. Zhu, T.; Cheng, R.; Lee, S.A.; Rajaraman, E.; Eiteman, M.A.; Querec, T.D.; Unger, E.R.; Mao, L. Continuous-flow ferrohydrodynamic sorting of particles and cells in microfluidic devices. Microfluid. Nanofluidics 2012, 13, 645-654. [CrossRef]

149. Zhao, W.; Cheng, R.; Jenkins, B.D.; Zhu, T.; Okonkwo, N.E.; Jones, C.E.; Davis, M.B.; Kavuri, S.K.; Hao, Z.; Schroeder, C.; et al. Label-free ferrohydrodynamic cell separation of circulating tumor cells. Lab Chip 2017, 17, 3097-3111. [CrossRef] [PubMed]

150. Zborowski, M.; Ostera, G.R.; Moore, L.R.; Milliron, S.; Chalmers, J.J.; Schechter, A.N. Red Blood Cell Magnetophoresis. Biophys. J. 2003, 84, 2638-2645. [CrossRef]

151. Inglis, D.W.; Riehn, R.; Sturm, J.C.; Austin, R.H. Microfluidic high gradient magnetic cell separation. J. Appl. Phys. 2006, 99, 08K101. [CrossRef]

152. Shamloo, A.; Yazdani, A.; Saghafifar, F. Investigation of a two-step device implementing magnetophoresis and dielectrophoresis for separation of circulating tumor cells from blood cells. Eng. Life Sci. 2020, 20, 296-304. [CrossRef]

153. Zborowski, M.; Chalmers, J.J. Magnetic Cell Separation; Elsevier Ltd.: Amsterdam, The Netherlands, 2008; ISBN 97804445275470444527540.

154. Woodside, S.M.; Milton, G.; Dowd, J. Magnetic Particles. U.S. Patent US9701935B2, 11 July 2017.

155. Ge, W.; Encinas, A.; Araujo, E.; Song, S. Magnetic matrices used in high gradient magnetic separation (HGMS): A review. Results Phys. 2017, 7, 4278-4286. [CrossRef]

156. Grützkau, A.; Radbruch, A. Small but mighty: How the MACS-technology based on nanosized superparamagnetic particles has helped to analyze the immune system within the last 20 years. Cytom. Part A 2010, 77, 643-647. [CrossRef] [PubMed]

157. Miltenyi, S.; Muller, W.; Weichel, W.; Radbruch, A. High Gradient Magnetic Cell Separation with MACS1. Cytometry 1990, 238, 231-238. [CrossRef]

158. Neurauter, A.A.; Bonyhadi, M.; Lien, E.; Nøkleby, L.; Ruud, E.; Camacho, S.; Aarvak, T. Cell isolation and expansion using Dynabeads ${ }^{\circledR}$. In Cell Separation; Kumar, A., Galaev, I.Y., Mattiasson, B., Eds.; Springer: Berlin/Heidelberg, Germany, 2007; pp. 41-73. ISBN 978-3-540-75263-9. 
159. Sun, L.; Zborowski, M.; Moore, L.R.; Chalmers, J.J. Continuous, flow-through immunomagnetic cell sorting in a quadrupole field. Cytometry 1998, 33, 469-475. [CrossRef]

160. Zborowski, M.; Sun, L.; Moore, L.R.; Stephen Williams, P.; Chalmers, J.J. Continuous cell separation using novel magnetic quadrupole flow sorter. J. Magn. Magn. Mater. 1999, 194, 224-230. [CrossRef]

161. Jing, Y.; Moore, L.R.; Schneider, T.; Williams, P.S.; Chalmers, J.J.; Farag, S.S.; Bolwell, B.; Zborowski, M. Negative selection of hematopoietic progenitor cells by continuous magnetophoresis. Exp. Hematol. 2007, 35, 662-672. [CrossRef] [PubMed]

162. Moore, L.R.; Williams, P.S.; Chalmers, J.J.; Zborowski, M. Tessellated permanent magnet circuits for flow-through, open gradient separations of weakly magnetic materials. J. Magn. Magn. Mater. 2017, 427, 325-330. [CrossRef]

163. Dennin, R.H.; Beyer, A. Application of scanning electron microscopy (SEM) and microbead techniques to study the localization of p24 and p18 antigens of HIV-1 on the surface of HIV-1-infected H9-lymphocytes. J. Microsc. 1991, 164, 53-60. [CrossRef]

164. Alnaimat, F.; Karam, S.; Mathew, B.; Mathew, B. Magnetophoresis and Microfluidics: A Great Union. IEEE Nanotechnol. Mag. 2020, 14, 24-41. [CrossRef]

165. Stevens, M.; Liu, P.; Niessink, T.; Mentink, A.; Abelmann, L.; Terstappen, L. Optimal Halbach Configuration for Flow-through Immunomagnetic CTC Enrichment. Diagnostics 2021, 11, 1020. [CrossRef]

166. Hoshino, K.; Huang, Y.-Y.; Lane, N.; Huebschman, M.; Uhr, J.W.; Frenkel, E.P.; Zhang, X. Microchip-based immunomagnetic detection of circulating tumor cells. Lab Chip 2011, 11, 3449-3457. [CrossRef]

167. Dumas-Bouchiat, F.; Zanini, L.F.; Kustov, M.; Dempsey, N.M.; Grechishkin, R.; Hasselbach, K.; Orlianges, J.C.; Champeaux, C.; Catherinot, A.; Givord, D. Thermomagnetically patterned micromagnets. Appl. Phys. Lett. 2010, 96, 102511. [CrossRef]

168. Zanini, L.F.; Dempsey, N.M.; Givord, D.; Reyne, G.; Dumas-Bouchiat, F. Autonomous micro-magnet based systems for highly efficient magnetic separation. Appl. Phys. Lett. 2011, 99, 232504. [CrossRef]

169. Wilbanks, J.J.; Kiessling, G.; Zeng, J.; Zhang, C.; Tzeng, T.-R.; Xuan, X. Exploiting magnetic asymmetry to concentrate diamagnetic particles in ferrofluid microflows. J. Appl. Phys. 2014, 115, 044907. [CrossRef]

170. Liu, Y.; Zhao, W.; Cheng, R.; Puig, A.; Hodgson, J.; Egan, M.; Cooper Pope, C.N.; Nikolinakos, P.G.; Mao, L. Label-free inertial-ferrohydrodynamic cell separation with high throughput and resolution. Lab Chip 2021, 21, 2738-2750. [CrossRef]

171. Mishra, A.; Dubash, T.D.; Edd, J.F.; Jewett, M.K.; Garre, S.G.; Karabacak, N.M.; Rabe, D.C.; Mutlu, B.R.; Walsh, J.R.; Kapur, R.; et al. Ultrahigh-throughput magnetic sorting of large blood volumes for epitope-agnostic isolation of circulating tumor cells. Proc. Natl. Acad. Sci. USA 2020, 117, 16839-16847. [CrossRef]

172. Bhuvanendran Nair Gourikutty, S.; Chang, C.P.; Puiu, P.D. Microfluidic immunomagnetic cell separation from whole blood. J. Chromatogr. B Anal. Technol. Biomed. Life Sci. 2016, 1011, 77-88. [CrossRef]

173. Huang, N.-T.; Hwong, Y.-J.; Lai, R.L. A microfluidic microwell device for immunomagnetic single-cell trapping. Microfluid. Nanofluidics 2018, 22, 16. [CrossRef]

174. Stott, S.L.; Hsu, C.-H.; Tsukrov, D.I.; Yu, M.; Miyamoto, D.T.; Waltman, B.A.; Rothenberg, S.M.; Shah, A.M.; Smas, M.E.; Korir G.K.; et al. Isolation of circulating tumor cells using a microvortex-generating herringbone-chip. Proc. Natl. Acad. Sci. USA 2010, 107, 18392-18397. [CrossRef]

175. Jung, S.H.; Hahn, Y.K.; Oh, S.; Kwon, S.; Um, E.; Choi, S.; Kang, J.H. Advection Flows-Enhanced Magnetic Separation for High-Throughput Bacteria Separation from Undiluted Whole Blood. Small 2018, 14, 1801731. [CrossRef] [PubMed]

176. Zhang, L.; Xu, Z.; Kang, Y.; Xue, P. Three-dimensional microfluidic chip with twin-layer herringbone structure for high efficient tumor cell capture and release via antibody-conjugated magnetic microbeads. Electrophoresis 2018, 39, 1452-1459. [CrossRef] [PubMed]

177. Shi, W.; Wang, S.; Maarouf, A.; Uhl, C.G.; He, R.; Yunus, D.; Liu, Y. Magnetic particles assisted capture and release of rare circulating tumor cells using wavy-herringbone structured microfluidic devices. Lab Chip 2017, 17, 3291-3299. [CrossRef] [PubMed]

178. Yang, M.; Wu, X.; Li, H.; Cui, G.; Bai, Z.; Wang, L.; Kraft, M.; Liu, G.; Wen, L. A novel rare cell sorting microfluidic chip based on magnetic nanoparticle labels. J. Micromech. Microeng. 2021, 31, 34003. [CrossRef]

179. Royet, D.; Hériveaux, Y.; Marchalot, J.; Scorretti, R.; Dias, A.; Dempsey, N.M.; Bonfim, M.; Simonet, P.; Frénéa-Robin, M. Using injection molding and reversible bonding for easy fabrication of magnetic cell trapping and sorting devices. J. Magn. Magn. Mater. 2017, 427, 306-313. [CrossRef]

180. Dempsey, N.M.; Le Roy, D.; Marelli-Mathevon, H.; Shaw, G.; Dias, A.; Kramer, R.B.G.; Viet Cuong, L.; Kustov, M.; Zanini, L.F.; Villard, C.; et al. Micro-magnetic imprinting of high field gradient magnetic flux sources. Appl. Phys. Lett. 2014, 104, 262401. [CrossRef]

181. Descamps, L.; Le Roy, D.; Tomba, C.; Deman, A.L. Magnetic polymers for magnetophoretic separation in microfluidic devices. Magnetochemistry 2021, 7, 100. [CrossRef]

182. Yu, X.; Feng, X.; Hu, J.; Zhang, Z.-L.; Pang, D.-W. Controlling the Magnetic Field Distribution on the Micrometer Scale and Generation of Magnetic Bead Patterns for Microfluidic Applications. Langmuir 2011, 27, 5147-5156. [CrossRef] [PubMed]

183. Xia, N.; Hunt, T.P.; Mayers, B.T.; Alsberg, E.; Whitesides, G.M.; Westervelt, R.M.; Ingber, D.E. Combined microfluidicmicromagnetic separation of living cells in continuous flow. Biomed. Microdevices 2006, 8, 299. [CrossRef]

184. Inglis, D.W.; Riehn, R.; Austin, R.H.; Sturm, J.C. Continuous microfluidic immunomagnetic cell separation. Appl. Phys. Lett. 2004, 85, 5093-5095. [CrossRef] 
185. Jung, J.; Han, K.H. Lateral-driven continuous magnetophoretic separation of blood cells. Appl. Phys. Lett. 2008, 93, 2006-2009. [CrossRef]

186. Kim, J.; Cho, H.; Han, S.-I.I.; Han, K.-H.H. Single-Cell Isolation of Circulating Tumor Cells from Whole Blood by Lateral Magnetophoretic Microseparation and Microfluidic Dispensing. Anal. Chem. 2016, 88, 4857-4863. [CrossRef] [PubMed]

187. Aldridge, P.M.; Mukhopadhyay, M.; Ahmed, S.U.; Zhou, W.; Christinck, E.; Makonnen, R.; Sargent, E.H.; Kelley, S.O. Prismatic Deflection of Live Tumor Cells and Cell Clusters. ACS Nano 2018, 12, 12692-12700. [CrossRef] [PubMed]

188. Faivre, M.; Gelszinnis, R.; Degouttes, J.; Terrier, N.; Rivière, C.; Ferrigno, R.; Deman, A.-L. Magnetophoretic manipulation in microsystem using carbonyl iron-polydimethylsiloxane microstructures. Biomicrofluidics 2014, 8, 54103. [CrossRef]

189. Earhart, C.M.; Hughes, C.E.; Gaster, R.S.; Ooi, C.C.; Wilson, R.J.; Zhou, L.Y.; Humke, E.W.; Xu, L.; Wong, D.J.; Willingham, S.B.; et al. Isolation and mutational analysis of circulating tumor cells from lung cancer patients with magnetic sifters and biochips. Lab Chip 2014, 14, 78-88. [CrossRef] [PubMed]

190. Saliba, A.-E.; Saias, L.; Psychari, E.; Minc, N.; Simon, D.; Bidard, F.-C.; Mathiot, C.; Pierga, J.-Y.; Fraisier, V.; Salamero, J.; et al. Microfluidic sorting and multimodal typing of cancer cells in self-assembled magnetic arrays. Proc. Natl. Acad. Sci. USA 2010, 107, 14524-14529. [CrossRef]

191. Malic, L.; Zhang, X.; Brassard, D.; Clime, L.; Daoud, J.; Luebbert, C.; Barrere, V.; Boutin, A.; Bidawid, S.; Farber, J.; et al. Polymer-based microfluidic chip for rapid and efficient immunomagnetic capture and release of Listeria monocytogenes. Lab Chip 2015, 15, 3994-4007. [CrossRef] [PubMed]

192. Huang, Y.Y.; Chen, P.; Wu, C.H.; Hoshino, K.; Sokolov, K.; Lane, N.; Liu, H.; Huebschman, M.; Frenkel, E.; Zhang, J.X.J.; et al. Screening and Molecular Analysis of Single Circulating Tumor Cells Using Micromagnet Array. Sci. Rep. 2015, 5, 1-11. [CrossRef]

193. Darabi, J.; Guo, C. On-chip magnetophoretic isolation of CD4 + T cells from blood. Biomicrofluidics 2013, 7, 54106. [CrossRef]

194. Besant, J.D.; Mohamadi, R.M.; Aldridge, P.M.; Li, Y.; Sargent, E.H.; Kelley, S.O. Velocity valleys enable efficient capture and spatial sorting of nanoparticle-bound cancer cells. Nanoscale 2015, 7, 6278-6285. [CrossRef]

195. Poudineh, M.; Sargent, E.H.; Kelley, S.O. Amplified Micromagnetic Field Gradients Enable High-Resolution Profiling of Rare Cell Subpopulations. ACS Appl. Mater. Interfaces 2017, 9, 25683-25690. [CrossRef]

196. Poudineh, M.; Aldridge, P.M.; Ahmed, S.; Green, B.J.; Kermanshah, L.; Nguyen, V.; Tu, C.; Mohamadi, R.M.; Nam, R.K.; Hansen, A.; et al. Tracking the dynamics of circulating tumour cell phenotypes using nanoparticle-mediated magnetic ranking. Nat. Nanotechnol. 2017, 12, 274-281. [CrossRef]

197. Nasiri, R.; Shamloo, A.; Akbari, J. Design of a hybrid inertial and magnetophoretic microfluidic device for CTCs separation from blood. Micromachines 2021, 12, 877. [CrossRef] [PubMed]

198. Ozkumur, E.; Shah, A.M.; Ciciliano, J.C.; Emmink, B.L.; Miyamoto, D.T.; Brachtel, E.; Yu, M.; Chen, P.-I.; Morgan, B.; Trautwein, J.; et al. Inertial Focusing for Tumor Antigen-Dependent and -Independent Sorting of Rare Circulating Tumor Cells. Sci. Transl. Med. 2013, 5, 179ra47. [CrossRef]

199. Kirby, D.; Glynn, M.; Kijanka, G.; Ducrée, J. Rapid and cost-efficient enumeration of rare cancer cells from whole blood by low-loss centrifugo-magnetophoretic purification under stopped-flow conditions. Cytom. A 2015, 87, 74-80. [CrossRef]

200. Bhagwat, N.; Dulmage, K.; Pletcher, C.H.; Wang, L.; DeMuth, W.; Sen, M.; Balli, D.; Yee, S.S.; Sa, S.; Tong, F.; et al. An integrated flow cytometry-based platform for isolation and molecular characterization of circulating tumor single cells and clusters. Sci. Rep. 2018, 8, 5035. [CrossRef]

201. Kim, U.; Soh, H.T. Simultaneous sorting of multiple bacterial targets using integrated Dielectrophoretic-Magnetic Activated Cell Sorter. Lab Chip 2009, 9, 2313. [CrossRef]

202. Shamloo, A.; Naghdloo, A.; Besanjideh, M. Cancer cell enrichment on a centrifugal microfluidic platform using hydrodynamic and magnetophoretic techniques. Sci. Rep. 2021, 11, 1939. [CrossRef]

203. Pereiro, I.; Tabnaoui, S.; Fermigier, M.; du Roure, O.; Descroix, S.; Viovy, J.-L.; Malaquin, L. Magnetic fluidized bed for solid phase extraction in microfluidic systems. Lab Chip 2017, 17, 1603-1615. [CrossRef] [PubMed]

204. Cui, F.; Ji, J.; Sun, J.; Wang, J.; Wang, H.; Zhang, Y.; Ding, H.; Lu, Y.; Xu, D.; Sun, X. A novel magnetic fluorescent biosensor based on graphene quantum dots for rapid, efficient, and sensitive separation and detection of circulating tumor cells. Anal. Bioanal. Chem. 2019, 411, 985-995. [CrossRef] [PubMed]

205. Pramanik, A.; Vangara, A.; Viraka Nellore, B.P.; Sinha, S.S.; Chavva, S.R.; Jones, S.; Ray, P.C. Development of Multifunctional Fluorescent-Magnetic Nanoprobes for Selective Capturing and Multicolor Imaging of Heterogeneous Circulating Tumor Cells. ACS Appl. Mater. Interfaces 2016, 8, 15076-15085. [CrossRef] [PubMed]

206. Martynenko, I.V.; Kusić, D.; Weigert, F.; Stafford, S.; Donnelly, F.C.; Evstigneev, R.; Gromova, Y.; Baranov, A.V.; Rühle, B.; Kunte, H.-J.; et al. Magneto-Fluorescent Microbeads for Bacteria Detection Constructed from Superparamagnetic Fe3O4 Nanoparticles and AIS/ZnS Quantum Dots. Anal. Chem. 2019, 91, 12661-12669. [CrossRef]

207. Poncelet, L.; Malic, L.; Clime, L.; Geissler, M.; Morton, K.J.; Nassif, C.; Da Fonte, D.; Veilleux, G.; Veres, T. Multifunctional magnetic nanoparticle cloud assemblies for in situ capture of bacteria and isolation of microbial DNA. Analyst 2021, 146, 7491-7750. [CrossRef]

208. Chen, F.; Haddour, N.; Frenea-Robin, M.; Chevolot, Y.; Monnier, V. Electroactive magnetic nanoparticles under magnetic attraction on a microchip electrochemical device. J. Magn. Magn. Mater. 2019, 475, 345-351. [CrossRef] 
209. Dou, B.; Xu, L.; Jiang, B.; Yuan, R.; Xiang, Y. Aptamer-Functionalized and Gold Nanoparticle Array-Decorated Magnetic Graphene Nanosheets Enable Multiplexed and Sensitive Electrochemical Detection of Rare Circulating Tumor Cells in Whole Blood. Anal. Chem. 2019, 91, 10792-10799. [CrossRef]

210. Wilson, R.E.; O'Connor, R.; Gallops, C.E.; Kwizera, E.A.; Noroozi, B.; Morshed, B.I.; Wang, Y.; Huang, X. Immunomagnetic Capture and Multiplexed Surface Marker Detection of Circulating Tumor Cells with Magnetic Multicolor Surface-Enhanced Raman Scattering Nanotags. ACS Appl. Mater. Interfaces 2020, 12, 47220-47232. [CrossRef] [PubMed]

211. Takahashi, M.; Mohan, P.; Mukai, K.; Takeda, Y.; Matsumoto, T.; Matsumura, K.; Takakura, M.; Arai, H.; Taguchi, T.; Maenosono, S. Magnetic Separation of Autophagosomes from Mammalian Cells Using Magnetic-Plasmonic Hybrid Nanobeads. ACS Omega 2017, 2, 4929-4937. [CrossRef]

212. Castro-Giner, F.; Aceto, N. Tracking cancer progression: From circulating tumor cells to metastasis. Genome Med. $2020,12,31$. [CrossRef]

213. Xiao, J.; Pohlmann, P.R.; Isaacs, C.; Weinberg, B.A.; He, A.R.; Schlegel, R.; Agarwal, S. Circulating Tumor Cells: Technologies and Their Clinical Potential in Cancer Metastasis. Biomedicines 2021, 9, 1111. [CrossRef] [PubMed]

214. Habli, Z.; Alchamaa, W.; Saab, R.; Kadara, H.; Khraiche, M.L. Circulating tumor cell detection technologies and clinical utility: Challenges and opportunities. Cancers 2020, 12, 1930. [CrossRef]

215. Rushton, A.J.; Nteliopoulos, G.; Shaw, J.A.; Coombes, R.C. A review of circulating tumour cell enrichment technologies. Cancers 2021, 13, 970. [CrossRef] [PubMed]

216. Pei, H.; Li, L.; Han, Z.; Wang, Y.; Tang, B. Recent advances in microfluidic technologies for circulating tumor cells: Enrichment, single-cell analysis, and liquid biopsy for clinical applications. Lab Chip 2020, 20, 3854-3875. [CrossRef]

217. Akpe, V.; Kim, T.H.; Brown, C.L.; Cock, I.E. Circulating tumour cells: A broad perspective. J. R. Soc. Interface 2020, $17,20200065$. [CrossRef]

218. Alvarez Cubero, M.J.; Lorente, J.A.; Robles-Fernandez, I.; Rodriguez-Martinez, A.; Puche, J.L.; Serrano, M.J. Circulating Tumor Cells: Markers and Methodologies for Enrichment and Detection. Methods Mol. Biol. 2017, 1634, 283-303. [CrossRef] [PubMed]

219. Andree, K.C.; van Dalum, G.; Terstappen, L.W.M.M. Challenges in circulating tumor cell detection by the CellSearch system. Mol. Oncol. 2016, 10, 395-407. [CrossRef] [PubMed]

220. Zhang, H.; Lin, X.; Huang, Y.; Wang, M.; Cen, C.; Tang, S.; Dique, M.R.; Cai, L.; Luis, M.A.; Smollar, J.; et al. Detection Methods and Clinical Applications of Circulating Tumor Cells in Breast Cancer. Front. Oncol. 2021, 11, 1816. [CrossRef]

221. Riethdorf, S.; Fritsche, H.; Müller, V.; Rau, T.; Schindlbeck, C.; Rack, B.; Janni, W.; Coith, C.; Beck, K.; Jänicke, F.; et al. Detection of circulating tumor cells in peripheral blood of patients with metastatic breast cancer: A validation study of the CellSearch system. Clin. Cancer Res. Off. J. Am. Assoc. Cancer Res. 2007, 13, 920-928. [CrossRef]

222. Millner, L.M.; Linder, M.W.; Valdes, R., Jr. Circulating tumor cells: A review of present methods and the need to identify heterogeneous phenotypes. Ann. Clin. Lab. Sci. 2013, 43, 295-304.

223. Gabriel, M.T.; Calleja, L.R.; Chalopin, A.; Ory, B.; Heymann, D. Circulating Tumor Cells: A Review of Non-EpCAM-Based Approaches for Cell Enrichment and Isolation. Clin. Chem. 2016, 62, 571-581. [CrossRef]

224. Grover, P.K.; Cummins, A.G.; Price, T.J.; Roberts-Thomson, I.C.; Hardingham, J.E. Circulating tumour cells: The evolving concept and the inadequacy of their enrichment by EpCAM-based methodology for basic and clinical cancer research. Ann. Oncol. Off. J. Eur. Soc. Med. Oncol. 2014, 25, 1506-1516. [CrossRef]

225. Satelli, A.; Batth, I.; Brownlee, Z.; Mitra, A.; Zhou, S.; Noh, H.; Rojas, C.R.; Li, H.; Meng, Q.H.; Li, S. EMT circulating tumor cells detected by cell-surface vimentin are associated with prostate cancer progression. Oncotarget 2017, 8, 49329-49337. [CrossRef]

226. Nicolazzo, C.; Gradilone, A.; Loreni, F.; Raimondi, C.; Gazzaniga, P. EpCAM(low) Circulating Tumor Cells: Gold in the Waste. Dis. Markers 2019, 2019, 1718920. [CrossRef]

227. Laget, S.; Broncy, L.; Hormigos, K.; Dhingra, D.M.; BenMohamed, F.; Capiod, T.; Osteras, M.; Farinelli, L.; Jackson, S.; PaterliniBréchot, P. Technical Insights into Highly Sensitive Isolation and Molecular Characterization of Fixed and Live Circulating Tumor Cells for Early Detection of Tumor Invasion. PLoS ONE 2017, 12, e0169427. [CrossRef] [PubMed]

228. Danila, D.C.; Samoila, A.; Patel, C.; Schreiber, N.; Herkal, A.; Anand, A.; Bastos, D.; Heller, G.; Fleisher, M.; Scher, H.I. Clinical Validity of Detecting Circulating Tumor Cells by AdnaTest Assay Compared With Direct Detection of Tumor mRNA in Stabilized Whole Blood, as a Biomarker Predicting Overall Survival for Metastatic Castration-Resistant Prostate Cancer Patients. Cancer J. 2016, 22, 315-320. [CrossRef] [PubMed]

229. Cho, H.; Chung, J.-S.; Han, K.-H. A Direct Comparison between the Lateral Magnetophoretic Microseparator and AdnaTest for Isolating Prostate Circulating Tumor Cells. Micromachines 2020, 11, 870. [CrossRef] [PubMed]

230. Scherag, F.D.; Niestroj-Pahl, R.; Krusekopf, S.; Lücke, K.; Brandstetter, T.; Rühe, J. Highly Selective Capture Surfaces on Medical Wires for Fishing Tumor Cells in Whole Blood. Anal. Chem. 2017, 89, 1846-1854. [CrossRef]

231. Vermesh, O.; Aalipour, A.; Ge, T.J.; Saenz, Y.; Guo, Y.; Alam, I.S.; Park, S.-M.; Adelson, C.N.; Mitsutake, Y.; Vilches-Moure, J.; et al. An intravascular magnetic wire for the high-throughput retrieval of circulating tumour cells in vivo. Nat. Biomed. Eng. 2018, 2, 696-705. [CrossRef]

232. Luo, L.; He, Y. Magnetically driven microfluidics for isolation of circulating tumor cells. Cancer Med. 2020, 9, 4207-4231. [CrossRef]

233. Lee, T.Y.; Hyun, K.-A.A.; Kim, S.-I.; Jung, H.-I. An integrated microfluidic chip for one-step isolation of circulating tumor cells. Sens. Actuators B Chem. 2017, 238, 1144-1150. [CrossRef] 
234. Cho, H.-Y.; Choi, J.-H.; Lim, J.; Lee, S.-N.; Choi, J.-W. Microfluidic Chip-Based Cancer Diagnosis and Prediction of Relapse by Detecting Circulating Tumor Cells and Circulating Cancer Stem Cells. Cancers 2021, 13, 1385. [CrossRef]

235. Chen, H.; Li, Y.; Zhang, Z.; Wang, S. Immunomagnetic separation of circulating tumor cells with microfluidic chips and their clinical applications. Biomicrofluidics 2020, 14, 41502. [CrossRef]

236. Autebert, J.; Coudert, B.; Champ, J.; Saias, L.; Guneri, E.T.; Lebofsky, R.; Bidard, F.-C.; Pierga, J.-Y.; Farace, F.; Descroix, S.; et al. High purity microfluidic sorting and analysis of circulating tumor cells: Towards routine mutation detection. Lab Chip 2015, 15, 2090-2101. [CrossRef]

237. Tang, M.; Wen, C.-Y.Y.; Wu, L.-L.L.; Hong, S.-L.L.; Hu, J.; Xu, C.-M.M.; Pang, D.-W.W.; Zhang, Z.-L.L. A chip assisted immunomagnetic separation system for the efficient capture and in situ identification of circulating tumor cells. Lab Chip 2016, 16, 1214-1223. [CrossRef]

238. Tang, M.; Xia, H.-F.; Xu, C.-M.; Feng, J.; Ren, J.-G.; Miao, F.; Wu, M.; Wu, L.-L.; Pang, D.-W.; Chen, G.; et al. Magnetic Chip Based Extracorporeal Circulation: A New Tool for Circulating Tumor Cell in Vivo Detection. Anal. Chem. 2019, 91, 15260-15266. [CrossRef]

239. Cho, H.; Kim, J.; Jeon, C.-W.; Han, K.-H. A disposable microfluidic device with a reusable magnetophoretic functional substrate for isolation of circulating tumor cells. Lab Chip 2017, 17, 4113-4123. [CrossRef] [PubMed]

240. Kang, H.; Kim, J.; Cho, H.; Han, K.-H. Evaluation of Positive and Negative Methods for Isolation of Circulating Tumor Cells by Lateral Magnetophoresis. Micromachines 2019, 10, 386. [CrossRef]

241. Poudineh, M.; Labib, M.; Ahmed, S.; Nguyen, L.N.M.; Kermanshah, L.; Mohamadi, R.M.; Sargent, E.H.; Kelley, S.O. Profiling Functional and Biochemical Phenotypes of Circulating Tumor Cells Using a Two-Dimensional Sorting Device. Angew. Chemie-Int. Ed. 2017, 56, 163-168. [CrossRef] [PubMed]

242. Zhou, J.; Kulasinghe, A.; Bogseth, A.; O’Byrne, K.; Punyadeera, C.; Papautsky, I. Isolation of circulating tumor cells in non-smallcell-lung-cancer patients using a multi-flow microfluidic channel. Microsyst. Nanoeng. 2019, 5, 8. [CrossRef]

243. Rossi, E.; Zamarchi, R. Single-Cell Analysis of Circulating Tumor Cells: How Far Have We Come in the-Omics Era? Front. Genet. 2019, 10, 958. [CrossRef] [PubMed]

244. Karabacak, N.M.; Spuhler, P.S.; Fachin, F.; Lim, E.J.; Pai, V.; Ozkumur, E.; Martel, J.M.; Kojic, N.; Smith, K.; Chen, P.; et al. Microfluidic, marker-free isolation of circulating tumor cells from blood samples. Nat. Protoc. 2014, 9, 694-710. [CrossRef]

245. Mutlu, B.R.; Smith, K.C.; Edd, J.F.; Nadar, P.; Dlamini, M.; Kapur, R.; Toner, M. Non-equilibrium Inertial Separation Array for High-throughput, Large-volume Blood Fractionation. Sci. Rep. 2017, 7, 9915. [CrossRef]

246. Fehm, T.N.; Meier-Stiegen, F.; Driemel, C.; Jäger, B.; Reinhardt, F.; Naskou, J.; Franken, A.; Neubauer, H.; Neves, R.P.L.; van Dalum, G.; et al. Diagnostic leukapheresis for CTC analysis in breast cancer patients: CTC frequency, clinical experiences and recommendations for standardized reporting. Cytom. A 2018, 93, 1213-1219. [CrossRef]

247. Lu, C.; Han, J.; Sun, X.; Yang, G. Electrochemical Detection and Point-of-Care Testing for Circulating Tumor Cells: Current Techniques and Future Potentials. Sensors 2020, 20, 6073. [CrossRef] [PubMed]

248. Chen, Y.; Chen, X.; Li, M.; Fan, P.; Wang, B.; Zhao, S.; Yu, W.; Zhang, S.; Tang, Y.; Gao, T. A new analytical platform for potential point-of-care testing of circulating tumor cells. Biosens. Bioelectron. 2021, 171, 112718. [CrossRef]

249. Kalligosfyri, P.; Nikou, S.; Bravou, V.; Kalogianni, D.P. Liquid biopsy genotyping by a simple lateral flow strip assay with visual detection. Anal. Chim. Acta 2021, 1163, 338470. [CrossRef] [PubMed]

250. Yang, J.; Huang, X.; Gan, C.; Yuan, R.; Xiang, Y. Highly specific and sensitive point-of-care detection of rare circulating tumor cells in whole blood via a dual recognition strategy. Biosens. Bioelectron. 2019, 143, 111604. [CrossRef]

251. Issadore, D.; Chung, J.; Shao, H.; Liong, M.; Ghazani, A.A.; Castro, C.M.; Weissleder, R.; Lee, H. Ultrasensitive clinical enumeration of rare cells ex vivo using a micro-hall detector. Sci. Transl. Med. 2012, 4, 141ra92. [CrossRef]

252. Issadore, D. Point-of-care rare cell cancer diagnostics. Methods Mol. Biol. 2015, 1256, 123-137. [CrossRef]

253. Hong, B.; Zu, Y. Detecting circulating tumor cells: Current challenges and new trends. Theranostics 2013, 3, 377-394. [CrossRef]

254. Law, J.W.-F.; Ab Mutalib, N.-S.; Chan, K.-G.; Lee, L.-H. Rapid methods for the detection of foodborne bacterial pathogens: Principles, applications, advantages and limitations. Front. Microbiol. 2015, 5, 770. [CrossRef] [PubMed]

255. Papadakis, G.; Murasova, P.; Hamiot, A.; Tsougeni, K.; Kaprou, G.; Eck, M.; Rabus, D.; Bilkova, Z.; Dupuy, B.; Jobst, G.; et al. Micro-nano-bio acoustic system for the detection of foodborne pathogens in real samples. Biosens. Bioelectron. 2018, 111, 52-58. [CrossRef]

256. Wang, Z.; Cai, R.; Gao, Z.; Yuan, Y.; Yue, T. Immunomagnetic separation: An effective pretreatment technology for isolation and enrichment in food microorganisms detection. Compr. Rev. Food Sci. Food Saf. 2020, 19, 3802-3824. [CrossRef]

257. Chen, J.; Park, B. Effect of immunomagnetic bead size on recovery of foodborne pathogenic bacteria. Int. J. Food Microbiol. 2018, 267, 1-8. [CrossRef] [PubMed]

258. Lim, M.-C.; Park, J.Y.; Park, K.; Ok, G.; Jang, H.-J.; Choi, S.-W. An automated system for separation and concentration of food-borne pathogens using immunomagnetic separation. Food Control 2017, 73, 1541-1547. [CrossRef]

259. Fedio, W.M.; Jinneman, K.C.; Yoshitomi, K.J.; Zapata, R.; Wendakoon, C.N.; Browning, P.; Weagant, S.D. Detection of E. coli O157:H7 in raw ground beef by Pathatrix ${ }^{\mathrm{TM}}$ immunomagnetic-separation, real-time PCR and cultural methods. Int. J. Food Microbiol. 2011, 148, 87-92. [CrossRef]

260. Wang, Z.; Yue, T.; Yuan, Y.; Cai, R.; Niu, C.; Guo, C. Development and evaluation of an immunomagnetic separation-ELISA for the detection of Alicyclobacillus spp. in apple juice. Int. J. Food Microbiol. 2013, 166, 28-33. [CrossRef] 
261. Yao, L.; Wang, L.; Huang, F.; Cai, G.; Xi, X.; Lin, J. A microfluidic impedance biosensor based on immunomagnetic separation and urease catalysis for continuous-flow detection of E. coli O157:H7. Sens. Actuators B Chem. 2018, 259, 1013-1021. [CrossRef]

262. Kanayeva, D.A.; Wang, R.; Rhoads, D.; Erf, G.F.; Slavik, M.F.; Tung, S.; Li, Y. Efficient separation and sensitive detection of Listeria monocytogenes using an impedance immunosensor based on magnetic nanoparticles, a microfluidic chip, and an interdigitated microelectrode. J. Food Prot. 2012, 75, 1951-1959. [CrossRef]

263. You, S.-M.; Luo, K.; Jung, J.-Y.; Jeong, K.-B.; Lee, E.-S.; Oh, M.-H.; Kim, Y.-R. Gold Nanoparticle-Coated Starch Magnetic Beads for the Separation, Concentration, and SERS-Based Detection of E. coli O157:H7. ACS Appl. Mater. Interfaces 2020, 12, 18292-18300. [CrossRef]

264. Wang, J.; Wu, X.; Wang, C.; Rong, Z.; Ding, H.; Li, H.; Li, S.; Shao, N.; Dong, P.; Xiao, R.; et al. Facile Synthesis of Au-Coated Magnetic Nanoparticles and Their Application in Bacteria Detection via a SERS Method. ACS Appl. Mater. Interfaces 2016, 8 , 19958-19967. [CrossRef] [PubMed]

265. Yuan, K.; Mei, Q.; Guo, X.; Xu, Y.; Yang, D.; Sánchez, B.J.; Sheng, B.; Liu, C.; Hu, Z.; Yu, G.; et al. Antimicrobial peptide based magnetic recognition elements and Au@Ag-GO SERS tags with stable internal standards: A three in one biosensor for isolation, discrimination and killing of multiple bacteria in whole blood. Chem. Sci. 2018, 9, 8781-8795. [CrossRef]

266. Zhang, L.; Wei, Q.; Han, Q.; Chen, Q.; Tai, W.; Zhang, J.; Song, Y.; Xia, X. Detection of Shigella in Milk and Clinical Samples by Magnetic Immunocaptured-Loop-Mediated Isothermal Amplification Assay. Front. Microbiol. 2018, 9, 94. [CrossRef]

267. Suh, S.H.; Dwivedi, H.P.; Jaykus, L.-A. Development and evaluation of aptamer magnetic capture assay in conjunction with real-time PCR for detection of Campylobacter jejuni. LWT-Food Sci. Technol. 2014, 56, 256-260. [CrossRef]

268. Ozalp, V.C.; Bayramoglu, G.; Erdem, Z.; Arica, M.Y. Pathogen detection in complex samples by quartz crystal microbalance sensor coupled to aptamer functionalized core-shell type magnetic separation. Anal. Chim. Acta 2015, 853, 533-540. [CrossRef]

269. Feng, J.; Dai, Z.; Tian, X.; Jiang, X. Detection of Listeria monocytogenes based on combined aptamers magnetic capture and loop-mediated isothermal amplification. Food Control 2018, 85, 443-452. [CrossRef]

270. Sarkar, T.; Chetia, M.; Chatterjee, S. Antimicrobial Peptides and Proteins: From Nature's Reservoir to the Laboratory and Beyond. Front. Chem. 2021, 9, 432. [CrossRef] [PubMed]

271. Kretzer, J.W.; Lehmann, R.; Schmelcher, M.; Banz, M.; Kim, K.-P.; Korn, C.; Loessner, M.J. Use of High-Affinity Cell Wall-Binding Domains of Bacteriophage Endolysins for Immobilization and Separation of Bacterial Cells. Appl. Environ. Microbiol. 2007, 73, 1992-2000. [CrossRef]

272. Park, C.; Kong, M.; Lee, J.-H.; Ryu, S.; Park, S. Detection of Bacillus Cereus Using Bioluminescence Assay with Cell Wall-binding Domain Conjugated Magnetic Nanoparticles. BioChip J. 2018, 12, 287-293. [CrossRef]

273. Thanyasrisung, P.; Vittayaprasit, A.; Matangkasombut, O.; Sugai, M.; Na Nongkai, P.; Saipia, S.; Hoven, V.P. Separation and detection of mutans streptococci by using magnetic nanoparticles stabilized with a cell wall binding domain-conjugated polymer. Anal. Methods 2018, 10, 3332-3339. [CrossRef]

274. Wang, Z.; Wang, D.; Chen, J.; Sela, D.A.; Nugen, S.R. Development of a novel bacteriophage based biomagnetic separation method as an aid for sensitive detection of viable Escherichia coli. Analyst 2016, 141, 1009-1016. [CrossRef]

275. Janczuk, M.; Richter, Ł.; Hoser, G.; Kawiak, J.; Łoś, M.; Niedziółka-Jönsson, J.; Paczesny, J.; Hołyst, R. Bacteriophage-Based Bioconjugates as a Flow Cytometry Probe for Fast Bacteria Detection. Bioconjug. Chem. 2017, 28, 419-425. [CrossRef]

276. Wei, S.; Chelliah, R.; Rubab, M.; Oh, D.-H.; Uddin, M.J.; Ahn, J. Bacteriophages as Potential Tools for Detection and Control of Salmonella spp. in Food Systems. Microorganisms 2019, 7, 570. [CrossRef]

277. Smartt, A.E.; Xu, T.; Jegier, P.; Carswell, J.J.; Blount, S.A.; Sayler, G.S.; Ripp, S. Pathogen detection using engineered bacteriophages. Anal. Bioanal. Chem. 2012, 402, 3127-3146. [CrossRef]

278. Wang, Z.; Wang, D.; Kinchla, A.J.; Sela, D.A.; Nugen, S.R. Rapid screening of waterborne pathogens using phage-mediated separation coupled with real-time PCR detection. Anal. Bioanal. Chem. 2016, 408, 4169-4178. [CrossRef]

279. He, Y.; Wang, M.; Fan, E.; Ouyang, H.; Yue, H.; Su, X.; Liao, G.; Wang, L.; Lu, S.; Fu, Z. Highly Specific Bacteriophage-Affinity Strategy for Rapid Separation and Sensitive Detection of Viable Pseudomonas aeruginosa. Anal. Chem. 2017, 89, 1916-1921. [CrossRef]

280. Kretzer, J.W.; Schmelcher, M.; Loessner, M.J. Ultrasensitive and Fast Diagnostics of Viable Listeria Cells by CBD Magnetic Separation Combined with A511::luxAB Detection. Viruses 2018, 10, 626. [CrossRef] [PubMed]

281. Schmelcher, M.; Loessner, M.J. Application of bacteriophages for detection of foodborne pathogens. Bacteriophage 2014, 4, e28137. [CrossRef] [PubMed]

282. Sonker, M.; Sahore, V.; Woolley, A.T. Recent advances in microfluidic sample preparation and separation techniques for molecular biomarker analysis: A critical review. Anal. Chim. Acta 2017, 986, 1-11. [CrossRef] [PubMed]

283. Kant, K.; Shahbazi, M.-A.; Dave, V.P.; Ngo, T.A.; Chidambara, V.A.; Than, L.Q.; Bang, D.D.; Wolff, A. Microfluidic devices for sample preparation and rapid detection of foodborne pathogens. Biotechnol. Adv. 2018, 36, 1003-1024. [CrossRef]

284. Pereiro, I.; Bendali, A.; Tabnaoui, S.; Alexandre, L.; Srbova, J.; Bilkova, Z.; Deegan, S.; Joshi, L.; Viovy, J.-L.L.; Malaquin, L.; et al. A new microfluidic approach for the one-step capture, amplification and label-free quantification of bacteria from raw samples. Chem. Sci. 2017, 8, 1329-1336. [CrossRef]

285. Alexandre, L.; Pereiro, I.; Bendali, A.; Tabnaoui, S.; Srbova, J.; Bilkova, Z.; Deegan, S.; Joshi, L.; Viovy, J.-L.; Malaquin, L.; et al. A microfluidic fluidized bed to capture, amplify and detect bacteria from raw samples. Microfluid. Cell Biol. Part B Microfluid. Single Cells 2018, 147, 59-75. [CrossRef] 
286. Srbova, J.; Krulisova, P.; Holubova, L.; Pereiro, I.; Bendali, A.; Hamiot, A.; Podzemna, V.; Macak, J.; Dupuy, B.; Descroix, S.; et al. Advanced immunocapture of milk-borne Salmonella by microfluidic magnetically stabilized fluidized bed. Electrophoresis 2018, 39, 526-533. [CrossRef]

287. Guo, P.L.; Tang, M.; Hong, S.L.; Yu, X.; Pang, D.W.; Zhang, Z.L. Combination of dynamic magnetophoretic separation and stationary magnetic trap for highly sensitive and selective detection of Salmonella typhimurium in complex matrix. Biosens. Bioelectron. 2015, 74, 628-636. [CrossRef]

288. Milesi, F.; Giacometti, M.; Coppadoro, L.P.; Ferrari, G.; Fiore, G.B.; Bertacco, R. On-Chip Selective Capture and Detection of Magnetic Fingerprints of Malaria. Sensors 2020, 20, 4972. [CrossRef] [PubMed]

289. Nam, J.; Huang, H.; Lim, H.; Lim, C.; Shin, S. Magnetic Separation of Malaria-Infected Red Blood Cells in Various Developmental Stages. Anal. Chem. 2013, 85, 7316-7323. [CrossRef] [PubMed]

290. Deshmukh, S.S.; Shakya, B.; Chen, A.; Durmus, N.G.; Greenhouse, B.; Egan, E.S.; Demirci, U. Multiparametric biophysical profiling of red blood cells in malaria infection. Commun. Biol. 2021, 4, 697. [CrossRef]

291. Wu, W.-T.; Martin, A.B.; Gandini, A.; Aubry, N.; Massoudi, M.; Antaki, J.F. Design of microfluidic channels for magnetic separation of malaria-infected red blood cells. Microfluid. Nanofluid. 2016, 20, 41. [CrossRef] [PubMed]

292. Zimmerman, P.A.; Fujioka, H.; Thomson, J.M.; Zborowski, M.; Collins, W.E. Diagnosis of malaria by magnetic deposition microscopy. Am. J. Trop. Med. Hyg. 2006, 74, 568-572. [CrossRef]

293. Klebanoff, C.A.; Gattinoni, L.; Restifo, N.P. Sorting Through Subsets. J. Immunother. 2012, 35, 651-660. [CrossRef]

294. Zhang, Q.; Yin, T.; Xu, R.; Gao, W.; Zhao, H.; Shapter, J.G.; Wang, K.; Shen, Y.; Huang, P.; Gao, G.; et al. Large-scale immunomagnetic cell sorting of T cells based on a self-designed high-throughput system for potential clinical application. Nanoscale 2017, 9, 13592-13599. [CrossRef]

295. Boyle, D.S.; Hawkins, K.R.; Steele, M.S.; Singhal, M.; Cheng, X. Emerging technologies for point-of-care CD4 T-lymphocyte counting. Trends Biotechnol. 2012, 30,45-54. [CrossRef]

296. Mair, B.; Aldridge, P.M.; Atwal, R.S.; Philpott, D.; Zhang, M.; Masud, S.N.; Labib, M.; Tong, A.H.Y.; Sargent, E.H.; Angers, S.; et al. High-throughput genome-wide phenotypic screening via immunomagnetic cell sorting. Nat. Biomed. Eng. 2019, 3, 796-805. [CrossRef] [PubMed]

297. Wang, Z.; Kelley, S.O. Ultrasensitive detection and depletion of rare leukemic b cells in t cell populations via microfluidicsmediated immunomagnetic cell ranking. In Proceedings of the MicroTAS 2020-24th International Conference on Miniaturized Systems for Chemistry and Life Sciences, Online, 4-9 October 2020; pp. 729-730.

298. Ng, A.P.; Alexander, W.S. Haematopoietic stem cells: Past, present and future. Cell Death Discov. 2017, 3, 17002. [CrossRef] [PubMed]

299. Plouffe, B.D.; Kevlahan, S.H. QuickBeads ${ }^{\mathrm{TM}}$ : Magnetic isolation of rare stem cells via a capture and release platform. In Proceedings of the 2014 40th Annual Northeast Bioengineering Conference (NEBEC), Boston, MA, USA, 25-27 April 2014; pp. 1-2.

300. Fratzl, M.; Delshadi, S.; Devillers, T.; Bruckert, F.; Cugat, O.; Dempsey, N.M.; Blaire, G. Magnetophoretic induced convective capture of highly diffusive superparamagnetic nanoparticles. Soft Matter 2018, 14, 2671-2681. [CrossRef] [PubMed] 